\title{
THE SPECIES OF THE GENUS PSEUDONIPHARGUS CHEVREUX, 1901 (AMPHIPODA) FROM NORTHERN SPAIN*
}

\author{
JOS NOTENBOOM \\ Institute of Taxonomic Zoology, University of Amsterdam, P.O. Box 20125, 1000 HC Amsterdam, \\ The Netherlands
}

\begin{abstract}
Based on new material collected in 1983, 1984, and 1985, the genus Pseudoniphargus proves to be distributed in northern Spain from Asturias, in the western part of the Cordillera Cantabrica, to Navarra and Huesca, in the headlands of the Pyrenees; and from coastal Atlantic regions up to the northern border of the Meseta. A total of 13 species are recognized, of which 11 are new. They are not only found in cave waters, but also in springs, hyporheic habitats, and wells.

The species are allopatric in distribution; burgensis $\mathbf{n}$. sp., eborarius n. sp., unisexualis Stock, 1980, and spiniferus n. sp. are known from single localities only; jereanus n. sp., gorbeanus n. sp., vasconiensis n. sp., incantatus n. sp., and guernicae n. sp. have more or less small distribution ranges; longicarpus $\mathbf{n}$. sp., semielongatus $\mathbf{n}$. sp., and montanus n. sp. are distributed in the underflows of some adjacent rivers; and finally elongatus Stock, 1980 has a large distribution, particularly in caves.

Morphological differences between the species are in general small, characters considered of major diagnostic importance are found in gnathopod 2, coxal plates, basis and claws of pereiopods 5 to 7 , uropod 3 , and telson.
\end{abstract}

\section{RESUMEN}

Este estudio muestra que el género Pseudoniphargus se encuentra en el norte de España desde Asturias, en el parte occidental de la Cordillera Cantabrica, hasta Navarra y Huesca, en el inicio de los Pirineos; y desde áreas costeras atlánticas hasta el límite norte de la Meseta. En total 13 especies fueron reconocidas, de las cuales 11 nuevas. No sólo fueron encontradas en aguas de cuevas, sino también en manantiales, hábitat hyporreicos, y pozos.

Las especies tienen una distribución alopátrica; burgensis sp. n., eborarius sp. n., unisexualis Stock, 1980, y spiniferus sp. n. se conocen de una sola localidad; jereanus sp. n., gorbeanus sp. n., vasconiensis sp. n., incantatus sp. n., y guernicae sp. n. tienen áreas de distribución más o menos pequeñas; longicarpus sp. n., semielongatus sp. n., y montanus sp. $\mathrm{n}$. se encuentran en aguas subterráneas de los cauces de ríos vecinos; finalmente elongatus Stock, 1980 tiene una distribución amplia, encontrándose principalmente en cuevas.

\footnotetext{
- Groundwater crustaceans of Spain, 4.
}

En general, las diferencias morfológicas entre las especies son pequeñas, los carácteres diagnósticos considerados como más importantes se hallan en el gnatópodo 2, las placas coxales, los bases y uñas de las patas 5 hasta 7 , el urópodo 3 , y el telson.

\section{INTRODUCTION}

The distribution of Pseudoniphargus in the Iberian Peninsula is clearly segregated into three different ranges: the Cantabrian Mountains and Pyrenees, Andalucia and south Valencia, and central-west Portugal (Stock, 1980; Notenboom \& Meijers, 1985). The present paper, almost entirely based on new material, deals with the species of the first region, northern Spain.

The first records of Pseudoniphargus from this region date from 1937, when Schellenberg mentioned the occurrence of what was considered to be Ps. africanus Chevreux, 1901, from some caves in Cantabria (prov. Santander) and Guipuzcoa (Basque Country). Many years later, Margalef (1970a) published some new records of this species from two caves of Guipuzcoa, while the same author (Margalef, $1970 \mathrm{~b}$ ) also mentioned its existence in a cave at Huesca (Pyrenees) and two caves at Tarragona (Catalan hills). 'A new record was provided by Gomarin Guirado (1968) from a Cantabrian cave, close to one of the caves (Cueva de la Estación de Santa Isabel) already mentioned by Schellenberg (1937). Since its erection by Chevreux (1901), the genus Pseudoniphargus remained monotypic for a long time, although the type-species africanus was known for its great morphological and ecological plasticity. In 1978 G. Karaman rised the forma adriatica S. Karaman, 1955, to species level. It is actually 
known to be distributed in coastal groundwaters along the northern belt of the Mediterranean (Stock, 1980).

A revision of most of the existing materials attributed to the genus, supplied with new collections, some of which were already mentioned by Ginet (1977), was performed by Stock (1980). This author recognized nine species, distributed along the Mediterranean coasts of southern France, Italy and Yugoslavia, and in northern Algeria, in the Cantabrian Mountains, western Portugal, Madeira, and the Azores; ecologically ranging from marine interstitial waters to fresh cave waters up to 1000 $m$ in altitude. The distribution of the typespecies africanus was restricted to the wells around Annaba (Algeria). In the Cantabrian Mountains, Stock (1980) recognized two species and an unidentifiable population: elongatus distributed in caves of Cantabria and a population probably belonging to this species from Cueva de Landarbaso (Guipuzcoa), unisexualis from only one locality, the Cueva de San Adrian (Guipuzcoa), and Pseudoniphargus sp. 4 from Cueva de las Brujas (Guipuzcoa). A new species of Pseudoniphargus, maroccanus, has been recently described from fresh groundwaters (wells) at $1230 \mathrm{~m}$ altitude in the Middle Atlas near Azrou, Morocco, by Boutin \& Coineau (in press).

The present study is almost entirely based on material collected by us during an intensive groundwater sampling program in 1983 and 1984 (Notenboom \& Meijers, 1985), and on most of the material used by Stock (1980), both present in the collections of the Zoölogisch Museum Amsterdam (ZMA). Owing to this study the number of species and the ranges of Pseudoniphargus in northern Spain are strongly enlarged. Besides the two formerly known species, eleven new species have been recognized. They are described in this paper, resulting in an increase of the range of Pseudoniphargus in northern Spain to the south side of the Cantabrian Mountain chain and with some $150 \mathrm{~km}$ westwards (fig. 1). While previously Pseudoniphargus was known in northern Spain only from cave waters, our collections yielded also material from underflows of rivers (hyporheic habitats), springs, and wells.

\section{GEOGRAPHICAL DISTRIBUTION AND ECOLOGICAL CONSIDERATIONS}

\section{Generalities}

The Cordillera Cantabrica and the western Spanish Pyrenees, in which all the localities of Pseudoniphargus species described in this paper are situated, is a very mountainous region influenced by an Atlantic climate, consequently it is pluviose with mean annual rainfall from 800 to more than $1600 \mathrm{~mm}$. With exception of the higher karstified mountains and the southern slopes, the area is covered by a dense vegetation. Due to the high precipitation and the rugged topography, superficial and subterranean water movements are in general intensive.

The highest parts of the ridge are situated E.S.E. of Oviedo (east Asturias), in the northern part of León, and in western Cantabria. This area, principally composed of palaeozoic rocks, was uplifted during the Hercynian Mountain building, but it was also affected by Alpine orogeny in the Tertiary. The present day topography and the development of the actual river basins mainly originated after this last orogeny. Carbonate rocks are outcropping in the whole area, but have an important accumulation in the Picos de Europa, the highest group which reaches up to $2600 \mathrm{~m}$. In the Palaeozoic part of the mountains, especially in the Picos de Europa, ancient, inactive, subterranean drainage patterns are very rare. Most of the caves are active, deep, small, subvertical shafts. In the Picos de Europa the karstification, which is of an alpine type, was probably generated after neotectonic Quaternary movements (Collignan, 1985).

The eastern parts of the Cordillera Cantabrica (Cantabria, Basque Country and the northern parts of the provinces of Palencia and Burgos) have lower altitudes. This region is mainly composed of Cenozoic rocks, influenced only by the Alpine orogeny. Cretaceous, rather pure, limestones with high dissolution proper- 
ties are widely distributed in this area. In Cantabria the limestones have a rather vast extension, in -which karst features are well developed. There are strongly developed horizontal fossil galleries and the length of subterranean water courses is immense (fig. 2A). In northern Burgos and Basque Country many limestone outcrops are present, but generally they are rather small and separated by noncalcareous rocks. However, through the nature of these rocks, which are exposed to a very pluviose climate, important subterranean karst features have developed. The widely distributed karstified limestones give rise to a variety of subterranean biotopes. Pseudoniphargus species are found both in biotopes related to the unsaturated zone of the karst, such as dripwater pools in fossil (inactive) galleries, and in biotopes in connection with or part of the saturated zone of the karst, like streams and resurgences.

Numerous rivers take their rise in the Cordillera Cantabrica and the Pyrenees. At the north side these rivers are rather short and directly flowing into the Atlantic Ocean. The many streams with relatively short reaches generally have riverbeds with poorly sorted sediments often with large boulders, resulting in bad conditions for the existence of underflows, casu quo hyporheic habitats. An exception is formed by the lower courses of some rather large river systems, e.g. those around the Picos de Europa. Certain rivers are heavily charged with pollutants, viz. in the narrow, densely populated and industrialized valleys of northern Basque Country and the Asturian mining district.

The rivers arising at the southern slopes of the mountain chain are in the catchment areas of two different basins. Those of the western part are drained into the Río Douro, which flows to the west into the Atlantic Ocean, while the other rivers and those of the Pyrenees are draining into the Río Ebro, which flows to the Mediterranean. At the foot of the mountains these larger river systems have alluvial planes with well-sorted sediments, consequently with large general porosity and resulting in the existence of important underflows.

\section{Distribution of the species}

As noticed previously, the distribution of Pseudoniphargus in northern Spain (fig. 1) is more or less limited to the extension of the Cantabrian Mountain ridge and the southern headlands of the Pyrenees. The southern limit of the range probably coincides with the northern border of the central plateau of Spain, the Meseta. Southern localities in which Pseudoniphargus has been found are Matallana de Torio (León) with montanus, Moradillo de Sedano (Burgos) with spec. 1 (southernmost locality), and Ripodas (Navarra) with spiniferus. The groundwaters studied in the transition from the Cantabrian Mountains to the Meseta, especially south of the Ebro in north Burgos, where the investigations were concentrated, yielded Pseudoniphargus only very few times. But, because this area gets gradually dryer, suitable groundwater habitats are decreasing.

The western end of the range of Pseudoniphargus is just west of the line OviedoLeón. This seems to coincide with the boundary of the Carboniferous rocks. The exact delimitation of this line is still under consideration because more sampling west of it is necessary.

During our explorations groundwaters of the western Pyrenees only have been sampled. Pseudoniphargus appears not to be very frequent in this area. The easternmost locality found was at Ripodas (Navarra) near the border with Huesca. Margalef (1970b) cited a cave locality more to the east in Huesca near Villanua, north of Jaca, but despite sampling in this area Pseudoniphargus has not been found again. However, during our sampling program in this area almost exclusively hyporheic habitats were investigated. The same author records the existence of Pseudoniphargus in caves of the Catalan hills in the province of Tarragona. In the Catalan Pyrenees no records are known, but the existence of Pseudoniphargus cannot be excluded in this area.

The different species of Pseudoniphargus are allopatric in distribution (fig. 1). Two speciès are never found together in the same habitat, while nearly all ranges of the species are 
separated. Only two exceptions are found: burgensis is known from one locality within the range of elongatus, and unisexualis within the range of vasconiensis (but while unisexualis was found, at only one locality, at $1050 \mathrm{~m}$ altitude, the other localities with vasconiensis were situated between 300 and $650 \mathrm{~m}$ in altitude).

Four different types of distribution are found: (i) species found at one locality only; (ii) species known from a rather limited area; (iii) species occurring in the basins of some adjacent rivers; and (iv) species with a rather large extension not related to a single river basin or a single karst area. To the first group belong burgensis, eborarius, unisexualis, and spiniferus. The latter was found at one place in the underflow of the Río Areta, but most likely it has a larger distribution in the underflow of this river. The other species of this group are from karstic groundwaters and they are probably restricted to the hydrological system to which the sampled habitat belongs. Probably these species are endemic to isolated karst areas, such as the karst in which the Ojo Guareña cave system is developed (with burgensis), the karst which drains into Fuente de Marfil (with eborarius), and the karst at higher altitudes of the Sierra de Urkilla (with unisexualis).

The second group of species, with small ranges, is composed of jereanus, gorbeanus, vasconiensis, incantatus, and guernicae. The first two species are probably limited to a small karstic area, jereanus to the karst between Quincoces de Yuso and Orduña (Burgos), and gorbeanus to the karst of the Sierra de Gorbea (Alava, Vizcaya). Ps. vasconiensis is found in karstic and nonkarstic habitats at lower altitudes around the Sierra de Urkilla and Sierra de Aralar along the limits of Guipuzcoa, Alava, and Navarra. Ps. incantatus is found in karstic habitats and a mine gallery in a small area in northwest Guipuzcoa near the French border. Finally, guernicae is an inhabitant of karstic waters on both sides of the estuary of the Ria de Mundaca north of Guernica.

The species of the third group, longicarpus, semielongatus, and montanus, are limited to the western part of the range. Ps. longicarpus has been found in groundwaters predominantly related to the catchment areas of the Río Nalon and the lower course of the Río Sella, which are draining into the Atlantic Ocean and covering

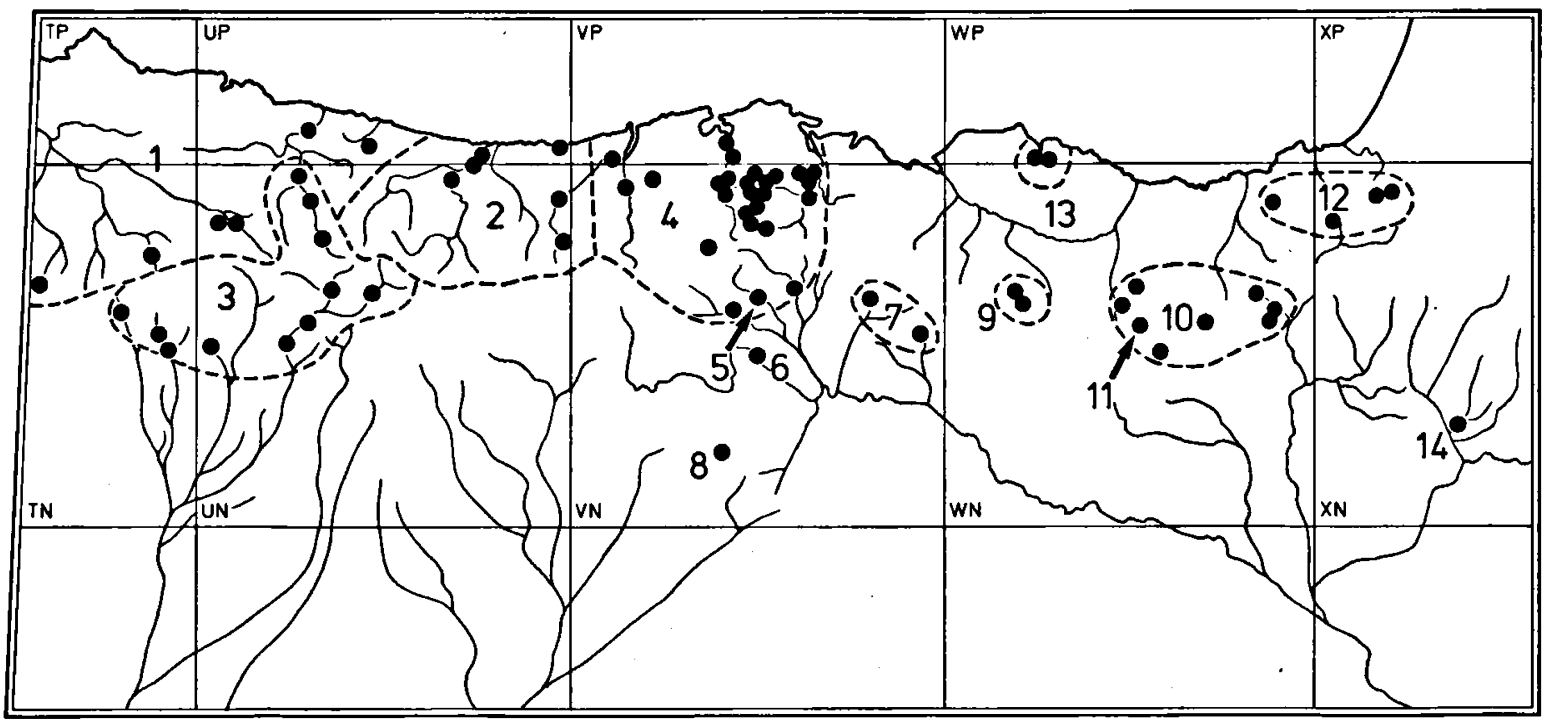

Fig. 1. Distribution of Pseudoniphargus species in northern Spain: 1, longicarpus n. sp.; 2, semielongatus n. sp.; 3, montanus n. sp.; 4, elongatus Stock, 1980; 5, burgensis n. sp.; 6, eborarius n. sp.; 7, jereanus n. sp.; 8, Pseudoniphargus sp. 1; 9, gorbeanus n. sp.; 10, vasconiensis n. sp.; 11, unisexualis Stock, 1980; 12, incantatus n. sp.; 13, guernicae n. sp.; 14, spiniferus n. sp. (Map provided with universal transverse mercator (UTM) grid, $100 \times 100 \mathrm{~km}$ squares indicated by letter codes.) 
large parts of eastern Asturias. The lower course of the Río Deva and the basin of the Río Saja are inhabited by semielongatus, while a population which probably belongs to this species is found in a cave near Comillas close to the sea coast. South of the Cantabrian Mountains, in the catchment area of the Río Douro, montanus has a large distribution in the upper courses of the basin of the Río Esla, but it reaches further north, across the watershed, in the upper course of the Río Sella.

The fourth group consists of one species, elongatus, which is widely distributed in the limestone areas of Cantabria; it also crossed the watershed and occurs in northernmost Burgos as well.

The different range sizes suggest better dispersal porperties for some species than for others. However, two problems should be kept in mind: first, owing to the cryptic nature of the fauna, complete ranges of many species are certainly not yet known, and second, the species treated here are morphological rather than biological entities of which some may be capable of interbreeding and therefore may be rather varieties or subspecies of the same biological species.

Remarkable is the distribution of Pseudoniphargus in the western part of the Cantabrian Mountain chain, compared with its distribution in the eastern part. In the western Palaeozoic mountains, Pseudoniphargus is almost exclusively distributed in nonkarstic habitats, the only exceptions being the records of longicarpus in small karst springs at little distance of the riverbank. Although several cave waters were investigated in the western part, particularly in the Sierra de Cuera, not any Pseudoniphargus was found, while asellote isopods occurred frequently. In the eastern Cenozoic mountains, cave waters were investigated as well, and very frequently Pseudoniphargus was found in cave pools, streams etc., often together with asellote isopods.

\section{Ecological considerations}

The chemical and physical parameters that have been determined (temperature, chlorinity, conductivity, $\mathrm{pH}$, and occasionally oxygen content), though limited, do not show any significant difference between the various groundwaters in which Pseudoniphargus species were found. The complete data set is presented in Notenboom \& Meijers (1985). All species discussed in this paper are found in infrahaline waters, the maximum chlorinity measured being $46 \mathrm{mg} / \mathrm{l}$ in a locality in the vicinity of the estuary of the Ria de Mundaca, north of Guernica (Basque Country). Furthermore, the waters are characterized by medium temperatures ranging between $7.5^{\circ} \mathrm{C}$ (cave streams in winter) to $16.0^{\circ} \mathrm{C}$ (underflows in summer); rather low electric conductivities varying between $200-500 \mu \mathrm{S} / \mathrm{cm}$, occasionally surpassing this value when the water is charged with pollutants, for example karst waters at lower altitudes of the densely populated coastal regions of Cantabria; and more or less neutral $\mathrm{pH}$ values. Only a few times oxygen content has been measured, all these values fell between 8 and $10 \mathrm{mg} / \mathrm{l}$.

The records for each species from different kinds of habitats are listed in table I. It would be premature to draw conclusions about habitat preferences of the species. The data are too limited and not in all areas every biotope has been investigated. For example, in the distribution area of montanus no karst waters have been sampled at all. Furthermore, wells and nonkarstic springs have not been as thoroughly investigated as cave waters and hyporheic habitats.

Five species have almost exclusively been recorded from hyporheic habitats: longicarpus, semielongatus, montanus, eborarius, and spiniferus. Of these, eborarius was collected from the underflow of a large karst spring, which probably has more important contacts with the karst waters than with the alluvial waters of the adjacent Río Ebro. The rivers in which the remaining species have been collected are situated in the western part of the region, viz. Río Nalon, Río Sella, Río Deva, Río Esla, and tributaries (fig. 2B); and, in the headlands of the Pyrenees, Río Areta with the only known locality of spiniferus. In the eastern part of the Cantabrian 
TABLE I

Records of species of Pseudoniphargus from different habitats, based on the records mentioned in this paper and those of Stock, 1980.

\begin{tabular}{|c|c|c|c|c|c|c|c|c|}
\hline & \multicolumn{3}{|c|}{ Caves } & \multicolumn{2}{|c|}{ Springs } & \multirow[t]{2}{*}{ Wells } & \multirow{2}{*}{$\begin{array}{l}\text { Hyporheic**) } \\
\text { habitats }\end{array}$} & \multirow{2}{*}{$\begin{array}{c}\text { Mine galleries } \\
\text { drip/seep } \\
\text { pools }\end{array}$} \\
\hline & streams & $\begin{array}{c}\text { drip/seep } \\
\text { pools }\end{array}$ & $\begin{array}{c}\text { phreatic } \\
\text { lakes }\end{array}$ & karst & others & & & \\
\hline longicarpus & & & & 2 & & & 5 & \\
\hline montanus & & & & & & 1 & 10 & \\
\hline semielongatus & & & $\left.1^{*}\right)$ & & & & 6 & \\
\hline elongatus & 10 & 11 & & 2 & & 2 & 6 & \\
\hline burgensis & 1 & & & & & & & \\
\hline eborarius & & & & & & & 1 & \\
\hline jereanus & 1 & & $\left.1^{*}\right)$ & & & & & \\
\hline gorbeanus & 2 & 4 & & & & & & \\
\hline unisexualis & & 1 & & & & & & \\
\hline vasconiensis & 2 & 1 & & 3 & 1 & & & \\
\hline incantatus & & 3 & & 2 & & & & 1 \\
\hline guernicae & 2 & & $\left.1^{*}\right)$ & 1 & & & & , \\
\hline spiniferus & & & & & & & 1 & \\
\hline
\end{tabular}

*) Small individuals provisionally classified with these species; ${ }^{* *}$ ) including the hyporheic habitats of karst springs.

Mountains, only elongatus was occasionally found in hyporheic habitats, viz. Río Yera (Cantabria) and Río Cerneja (Burgos). The rivers investigated in Basque Country did not yield any Pseudoniphargus, while other stygobiont animals have been very rarely found, but most of the time no samples in hyporheic habitats could be taken at all. In this part of the mountain chain the conditions for existence of river underflows are obviously bad. The rivers of northern Basque Country are rather short, intermittent and fast flowing, streambeds are composed of poorly sorted sediments with much shales, clay and often large boulders, consequently the general porosity and thereby the development of an underflow are probably limited. Moreover, many of the rivers crossing densely populated and industrialized valleys are heavily polluted.

Quite different are the rivers of the Picos de Europa. These arise on the slopes of a noncalcareous mountain ridge south of the Picos, and flow to the north through deeply carved gorges, draining directly into the Atlantic Ocean. Especially in the lower course of these rivers, in particular the Río Deva and the Río
Sella (fig. 2B), alluvial planes are well developed consisting of well-sorted gravels with an active underflow. In the hyporheic habitats of these rivers a rich stygofauna occurred, both in quantitative and in qualitative respect (e.g. Pseudoniphargus, Haploginglymus, Proasellus, Bragasellus, Synasellus, Stenasellus, Typhlocirolana, Bathynellacea).

Eight species are inhabitants of cave waters (see table I), of these only three have been found in groundwater habitats outside caves as well: elongatus was found in wells and hyporheic habitats (including the underflow of resurgences), vasconiensis in a spring rising from noncalcareous rocks, and incantatus in dripwater pools of a mine gallery, which, however, is located in a limestone area.

In caves Pseudoniphargus appears to prefer rimstone and other pools, and streams, especially smaller streams and trickles. Likewise, it prefers the presence of silt and clay, most likely because of availability of nutrients from these organically enriched sediments. Phreatic cave waters, found where cave passages intersect the groundwater table, which are deeper than pools, are not favoured by 

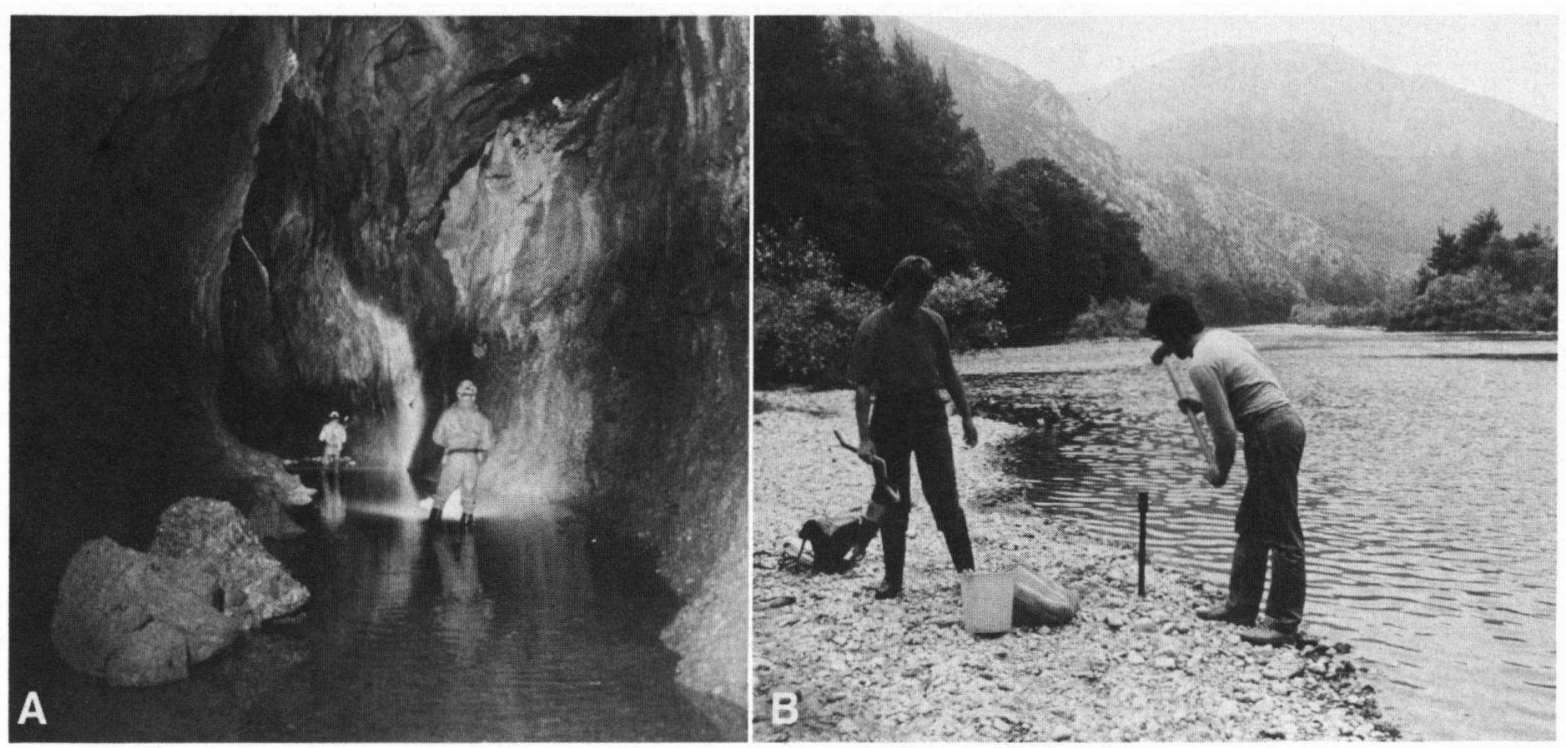

Fig. 2.A, Example of a large subterranean watercourse in Cantabria, main river of Cueva de Coventosa, inhabited by Pseudoniphargus elongatus Stock, 1980 together with Proasellus cantabricus Henry Magniez, 1968 and Cantabroniscus primitivus Vandel, 1965 (photograph by W. Hovenkamp). B, Lower course of a river north of the Picos de Europa, Río Sella near Fries (Oviedo), locality with Pseudoniphargus longicarpus n. sp., together with Typhlocirolana, Bragasellus, Stenasellus, Cyclopoidea, Prosobranchiate snails, insects, Nematoda and Oligochaeta (photograph by the author).

Pseudoniphargus; however, this kind of waters is difficult to sample.

Other malacostracan crustaceans occurring together with Pseudoniphargus are enumerated in table II. Co-occurrence of several of these elements is mainly geographically determined. So, the asellid isopods Synasellus and Bragasellus (only inhabiting the western part of the mountain chain), are frequently found here together with Ps. longicarpus, semielongatus, and montanus. The asellid isopod Proasellus which above all is found in the eastern part of the Cantabrian Mountain chain and in the headlands of the Pyrenees, occurs along with all the Pseudoniphargus species of this area. Members of the amphipod genus Niphargus, only inhabiting Basque Country and northwest Burgos, occur frequently together with Pseudoniphargus. The aquatic oniscoid isopod Cantabroniscus, distributed in cave streams only (fig. 2A) of a rather small area, Cantabria and northwest Burgos, often occurs together with Ps. elongatus. Salentinella and microparasellid isopods are rather rare in the north and absent in the western part of the Cordillera Cantabrica. Bathynellacea occur in the whole region, although rather rarely, and several times they have been found together with Pseudoniphargus. The cirolanid isopod Typhlocirolana was found only twice in the region, both times together with Pseudoniphargus (i.e. longicarpus and spiniferus).

In the whole region the isopod Stenasellus and the amphipod Haploginglymus are distributed. Stenasellus was regularly found together with Pseudoniphargus, both in cave waters, above all in pools with clayey bottoms, and in hyporheic habitats. Haploginglymus has never been found in the cave waters of northern Spain, it cooccurred with Pseudoniphargus in hyporheic habitats only. In the river system of the Río Deva (Picos de Europa) which was investigated at several localities, Haploginglymus shows a preference for the upper courses, while Pseudoniphargus prefers the lower courses. The two taxa were found together only in some localities in the lower course of the river. In the Río Cares, which debouches into the Río Deva, 
Co-occurrence of Pseudoniphargus species with other stygobiont malacostracan crustaceans $(n=$ total number of different habitats sampled per species).

\begin{tabular}{|c|c|c|c|c|c|c|c|c|c|c|}
\hline 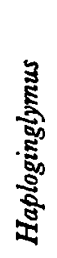 & 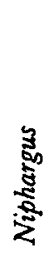 & 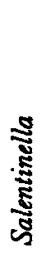 & 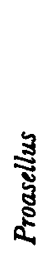 & 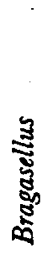 & 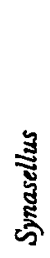 & 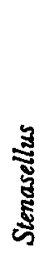 & 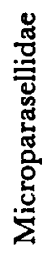 & 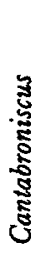 & 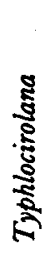 & 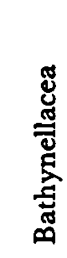 \\
\hline & & & & 4 & 4 & 1 & & & 1 & 1 \\
\hline 2 & & & 2 & 3 & 2 & & & & & \\
\hline 1 & & & & 6 & 4 & 2 & & r & & 3 \\
\hline 3 & & 2 & 13 & 2 & & 12 & 1 & 6 & & 2 \\
\hline 1 & & & 1 & & & & & & & \\
\hline 1 & 1 & & 1 & & & & & & & \\
\hline & & & 3 & & & 2 & & & & \\
\hline & 4 & & 3 & & & 1 & & & & \\
\hline & 5 & & 1 & & & & 1 & & & \\
\hline & 1 & & 1 & & & 3 & & & & \\
\hline 1 & & 1 & 1 & & & & 1 & & 1 & 1 \\
\hline
\end{tabular}

only Haploginglymus has been found. In the headlands of the Pyrenees many of the hyporheic habitats investigated yielded Haploginglymus, whereas Pseudoniphargus was found at one locality only, where it occurred jointly with Haploginglymus. We found frequent associations of Niphargus and Pseudoniphargus, but almost never (one exception) between Haploginglymus and Niphargus. These observations might suggest some kind of competition between several genera, resulting in the exclusion of Haploginglymus from habitats (or regions) inhabited by Niphargus and the sporadical co-occurrence in hyporheic habitats only of Pseudoniphargus with Haploginglymus.

\section{MORPHOLOGICAL REMARKS}

Morphological differences between the species of Pseudoniphargus are small, and in general restricted to a few appendages, particularly to the gnathopods, pereiopods (especially 5 to 7 ), uropods (especially 3), and telson. Each isolated population deviates more or less from another in morphology, and whether these differences are intra- or interspecific is often difficult to interpret. The characters which proved to be of differentiating value between the species during this study are enumerated in table III. Important is the different degree of elongation occurring in gnathopodal carpus and propodus, and in peduncle and exopodite of uropod 3.

The differences in degree of sexual dimorphism between the species are also of diagnostic value. Females of all species studied have relatively longer gill stalks than the males. In many of the species studied, the female carpus and propodus of gnathopod 2 are more elongated, while in some of these species this elongation becomes very conspicuous, for example in jereanus, gorbeanus, and incantatus. Striking is the different degree of elongation and sexual dimorphism of the third uropod between the species. In a rather large number of species this appendage is not elongated and identical in both sexes, e.g. in unisexualis, incantatus, vasconiensis, etc., but in one species, elongatus, peduncle and exopodite are elongated in females and strongly elongated in males. Slight elongation 


\section{TABLE III}

Characters of diagnostic importance in Pseudoniphargus from northern Spain.

\begin{tabular}{|c|c|}
\hline Antenna 1 & total length \\
\hline Antenna 2 & $\begin{array}{l}\text { setation of peduncular segments } 4 \text { and } 5 \\
\text { length of flagellar setae }\end{array}$ \\
\hline Mandible palp & $\begin{array}{l}\text { setation of segment } 2 \\
\text { number of D-setae }\end{array}$ \\
\hline Upper lip & width and length of inner lobe \\
\hline Maxilla 1 & $\begin{array}{l}\text { number of spines on outer lobe } \\
\text { denticulation of outer lobe spines }\end{array}$ \\
\hline Maxilliped & relative length of inner lobe \\
\hline $\begin{array}{l}\text { Gnathopods } \\
1 \neq 2\end{array}$ & $\begin{array}{l}\text { shape and distal setation of coxa } \\
\text { relative length of carpus } \\
\text { shape of propodus } \\
\text { number of palmar angle spines } \\
\text { density of armature along palmar } \\
\text { margin } \\
\text { length of dactylus and unguis } \\
\text { degree of sexual differentiation } \\
\text { (P2 only) }\end{array}$ \\
\hline $\begin{array}{l}\text { Pereiopods } \\
\quad 3 \approx 4\end{array}$ & $\begin{array}{l}\text { shape and distal setation of coxae } \\
\text { depth of posterior excavation coxa P4 } \\
\text { length of dactylus and unguis }\end{array}$ \\
\hline $\begin{array}{l}\text { Pereiopods } \\
5 \text { to } 7\end{array}$ & $\begin{array}{l}\text { length and shape of basis } \\
\text { degree of lobation of basis } \\
\text { length and density of spines on distal } \\
\text { segments } \\
\text { length of dactylus and unguis }\end{array}$ \\
\hline $\begin{array}{l}\text { Epimeral } \\
\text { plates }\end{array}$ & $\begin{array}{l}\text { armature of distal margin } \\
\text { shape of posterodistal angle }\end{array}$ \\
\hline Uropod 1 & $\begin{array}{l}\text { length of peduncle } \\
\text { presence or absence of basoventral } \\
\text { spine } \\
\text { presence or absence of medial peduncle } \\
\text { spines } \\
\text { relative length of distal peduncle spines } \\
\text { presence or absence of marginal spines } \\
\text { on rami } \\
\text { difference in length of rami }\end{array}$ \\
\hline Uropod 3 & $\begin{array}{l}\text { degree of elongation of peduncle } \\
\text { degree of elongation exopodite } \\
\text { relative length and number of exopodal } \\
\text { spines } \\
\text { degree of sexual differentiation }\end{array}$ \\
\hline Telson & $\begin{array}{l}\text { shape } \\
\text { width and depth of distal emargination } \\
\text { implantation and number of terminal } \\
\text { spines }\end{array}$ \\
\hline
\end{tabular}

of the exopodite of uropod 3 has been found only in longicarpus, semielongatus, and montanus, but in these species differences between the sexes are not, or only slightly developed.

Salient is also the degree of elongation of dactylus and unguis of pereiopods 3 to 7: in some species (e.g. burgensis, jereanus, incantatus) these are strongly elongated, while in some other species (e.g. unisexualis, spiniferus) they are short.

Another important character set within Pseudoniphargus is found in pereiopods 5 to 7 , especially in the shape of the basis. The posterior lobe of the basis is found to be expanded in some species, while in others it is narrow; the posterodistal angle can be strongly overhanging or obtuse. Small sexual differences are found in some species, but they are not considered of great importance.

In specimens from the same population the armature of the appendages appears to be subject to variation. During the present study an attempt has been made to compare as much as possible different individuals in order to understand the intraspecific variation. The density and length of the antennal setae, the distal setation of coxal plates 3 and 4 , the length of the spines on the distal segments of pereiopods 5 to 7 , the presence or absence of basoventral and medial spines on the peduncle of uropod 1, and the length and number of spines in each group on the margins of the exopodite of uropod 3 appear to be subject to small variations only and are regarded of diagnostic value, though of minor importance.

Another problem encountered is that of allometric growth. Diagnostic characters are best developed in larger individuals which have molted several times after maturity. Identification of samples with only small adult individuals of a large-sized species is difficult. It also implies that large samples are necessary to recognize a small-sized species. It is incorrect to think that if ovigerous females are present in the material studied, they are also fully developed. Many times morphological differences, for example in the gnathopodal carpus and propodus, 
and in the shape of the basis of pereiopods 5 to 7 , were found between small- and large-sized ovigerous females within the same population. Morphological differences between different mature instars of the same species were found above all in the density of armature, especially on the distal margins of coxal plates, carpus and propodus of gnathopods, basis of pereiopods 5 to 7, and uropodal rami; so the first mature instars have the propodus of gnathopod 2 more compact, and the shape of the basis of pereiopods 5 to 7 more rounded with a more obvious overhanging posterodistal angle.

The different forms of Pseudoniphargus recognized in northern Spain are described as morphological species in this paper. All these species are allopatric in distribution, some are morphologically more similar than others and nothing is known whether they are interfertile or intersterile. Since no biological information is available about these species, such as capability of interbreeding, isoenzyme variation, and autecology, but for their morphology and geographical distribution, it is hard to recognize entities below the species level such as sub- or semispecies.

\section{TAXONOMIG PART}

\section{Genus Pseudoniphargus Chevreux, 1901}

Diagnosis. - Blind, unpigmented. Body elongated. Antennal sinus shallow. Pedunculus of both antennae not elongated. A1 $\gg \mathrm{A} 2$. Cudgel-shaped aesthetascs present on distal flagellum segments of $\mathrm{A} 1$ (both sexes), absent on A2. Accessory flagellum short, 2-segmented.

Upper lip entire; lower lip wing-shaped, inner lobes prominent. Corpus of mandibulae asymmetrical; palp 3-segmented, well developed. Maxilla 1: outer lobe with (6-)7 spines, inner lobe with 2 setae, palp 2segmented with 4-8 distal elements. Maxilla 2: outer lobe wide, with 2 distal groups of setae; no oblique row of setae; inner lobe with ter- minal setae only. Maxilliped: inner lobe rather feebly developed, with a low number of distal setae and sometimes a few spines; outer lobe and palp well developed.

Gnathopods in several species sexually dimorphic. Merus of P1 with a membranous cushion armed with spinules, distally with a characteristic seta. Propodus of P2 $>$ propodus of P1. Carpus of P1 and P2 elongated in some species. Palmar angle armed with bifid (P1) or setule-tipped (P2) spines. Palmar margin armed with bifid spinules and a mid-palmar group of simple setae. Coxal gills with basal stalk, on P2-P6; stalk in female somewhat longer than in male. Coxal plates rather small; 4th plate with posterior excavation. Oostegites linear, with 3-12 setae. P6 and especially P7 elongated. Posterior lobe of P5-P7 weak or well developed, distal angle obtuse or produced, often weakly sexually dimorphic. Pleopods biramous, well developed; with two pinetreeshaped retinacula.

Uropod 1 well developed, basoventral spine and/or medial peduncle spines present or absent. Uropod 2 much smaller than uropod 1. Uropod 3 with long, 1-segmented exopodite and parviramus-type endopodite; nonnatatory. Exopodite and in some cases, pedunculus, elongated; in males of some species this elongation is extreme.

Telson entire, with distal spines and pair of sensory setules on either side, distally more or less notched.

Type-species. - Pseudoniphargus africanus Chevreux, 1901.

Species from northern Spain described in this paper: longicarpus n. sp., semielongatus n. sp., montanus n. sp., elongatus Stock, 1980, burgensis n. sp., eborarius n. sp., jereanus n. sp., sp. 1, gorbeanus $\mathrm{n}$. sp., vasconiensis $\mathrm{n}$. sp., unisexualis Stock, 1980, incantatus n. sp., guernicae n. sp., and spiniferus n. sp. A key to identify these species will be included in a next paper about the Pseudoniphargus species from southern Spain. 
Pseudoniphargus longicarpus n. sp.

(Figs. 3-4)

Material examined.** — Prov. Oviedo, Cangas de Onis, Fries, SBR Río Sella, UTM coordinates UP309095, alt. 15 m; 18 Apr. 1984 (sta. 84-4/28), 1 ㅇ holotype, 10 \$Q $\%$ and $50^{\circ} 0^{\circ}$ (paratypes) (ZMA coll. no. Amph. 108.026); 15 Oct. 1983 (sta. 83-10/15), 2 ơ $\sigma^{\circ}, 4$ $\$ Q$ and 5 juvs. (paratypes) (ZMA coll. no. Amph. 108.047).

Prov. Oviedo, Caso, Campo de Caso, SBR Río Nalon, UTM coordinates UN101836, alt. $560 \mathrm{~m} ; 17$ Oct. 1983 (sta. 83-10/24), 2 small $\$$ 우 (probably this species).

Prov. Oviedo, Caso, $1.5 \mathrm{~km} \mathrm{~S}$. of Coballes, SBR Río Caleao, UTM coordinates UN065841, alt. 500 m; 17 Oct. 1983 (sta. 83-10/28), 1 ơ.

Prov. Oviedo, Aller, Casomera, SBR Río de Aller, UTM coordinates TN906745, alt. $610 \mathrm{~m} ; 18$ Oct. 1983 (sta. 83-10/30), 1 o and 1 \%.

Prov. Oviedo, Aller, Riomañón, SBR Río de Aller, UTM coordinates TN905754, alt. 580 m; 18 Oct. 1983 (sta. 83-10/31), 4 우우.

Prov. Oviedo, Llanes, Debodes, caught karst spring below the Cuevas de Debodes, UTM coordinates UP461047, alt. $100 \mathrm{~m}$; 5 July 1984 (sta. 84-7/3), in dammed up brooklet, 2 우 (1 ovigerous).

Prov. Oviedo, caught karst spring at the E. side of the road Trubia - Puerto de Ventana, $0.5 \mathrm{~km} \mathrm{~S}$. of Tuñon, UTM coordinates TN5797, alt. $300 \mathrm{~m}$; 6 July 1984 (sta. 84-7/5), in crevices, 1 o.

Description. - Largest female (holotype, with setose oostegites) $6.5 \mathrm{~mm}$, males up to 3.5 $\mathrm{mm}$; only 1 ovigerous female of $3.5 \mathrm{~mm}$, from Debodes.

Female: Antenna 1 about $80 \%$ of body length; peduncle slender, scarcely armed with short setae; flagellum with up to 27 segments, aesthetascs about half the length of corresponding segments. Antenna 2: peduncle as long as peduncle of $A 1$, segments 4 and 5 (fig. 4d) with numerous setae, segment 4 also bearing some spines; flagellum of 6-9 segments.

Mandible palp (fig. 4e) slender, segment 1 relatively long, segment 2 with few distoventral setae, segment 3 armed with 2 A-setae, 2 Bsetae, $12 \mathrm{D}$-setae and 3 or $4 \mathrm{E}$-setae. Maxilla 1 (fig. 4f): outer lobe with 7 strong unidenticulate

** SBR and SKC indicate samples taken from the underflow of rivers (hyporheic habitats) by means of the biophreatical pump or Bou-Rouch probing ( $=\mathrm{SBR}$ ), or by means of digging a hole on the border of the river (- "sondage Karaman-Chappuis", SKC). spines, palp rather wide. Maxillipedal outer lobe with many spines on inner margin. Other mouthparts without peculiarities.

Gnathopod 1 (fig. 3d): coxa with convex distal margin bearing 3 setae; carpus strongly elongated, posterior margin with up to 9 setal rows; propodus shorter than carpus with 3 setal rows on posterior margin; palmar angle (fig. 3e) bearing 8 spines, palmar margin scarcely armed with some bifid spinules and some simple setae; dactylus short. Gnathopod 2 (fig. 3a): coxa ovoid with 3 distal setae; carpus strongly elongate, posterior margin bearing 10 setal rows; propodus slender with 5 groups of setae on posterior margin, 4 palmar angle spines (fig. $3 f)$; unguis about half the length of dactylus. Smaller specimens have less elongated carpus, fewer setal rows on posterior margins and only 3 palmar angle spines.

Oostegites linear, rather wide, bearing 8-10 setae. Coxal plate of P3 (fig. 3c) narrow, convex distal margin armed with 3 setae; coxal plate of P4 (fig. 3b) much wider than that of P3, posterior excavation well developed, distal margin with 7 setae. Claws of P3 to P7 not elongated.

Pereiopods 5 to 7 : basis (figs. $4 \mathrm{a}, \mathrm{b}, \mathrm{c}$ ) with wide posterior lobe, and overhanging posterodistal angle; distal segments with rather long spines. Basis of P5 to P7 in smaller specimens more compact, and with more strongly overhanging posterodistal angle. P5 slender, basis (fig. 4a) anteriorly with 3 little spines, posteriorly 5 setules. Basis of P6 (fig. 4b) little longer than basis of P5 and P7, margins anteriorly with 4 little spines and posteriorly with about 7 setules. Basis of P7 (fig. 4c) wider than in P5 and P6, margins armed with 4 little spines anteriorly and with 8 setules posteriorly.

Epimera (fig. $3 \mathrm{~h}$ ): plate 1 rounded; plates 2 and 3 with rectangular posteroventral corners, lower margin of both with 2 spines.

Uropod 1 (fig. $3 \mathrm{j}$ ): slender peduncle with long and curved basoventral spine, 3 slender medial spines, dorsal row of 6 long spines, and long distal spines; rami slender, exopodite shorter than endopodite, with few slender 


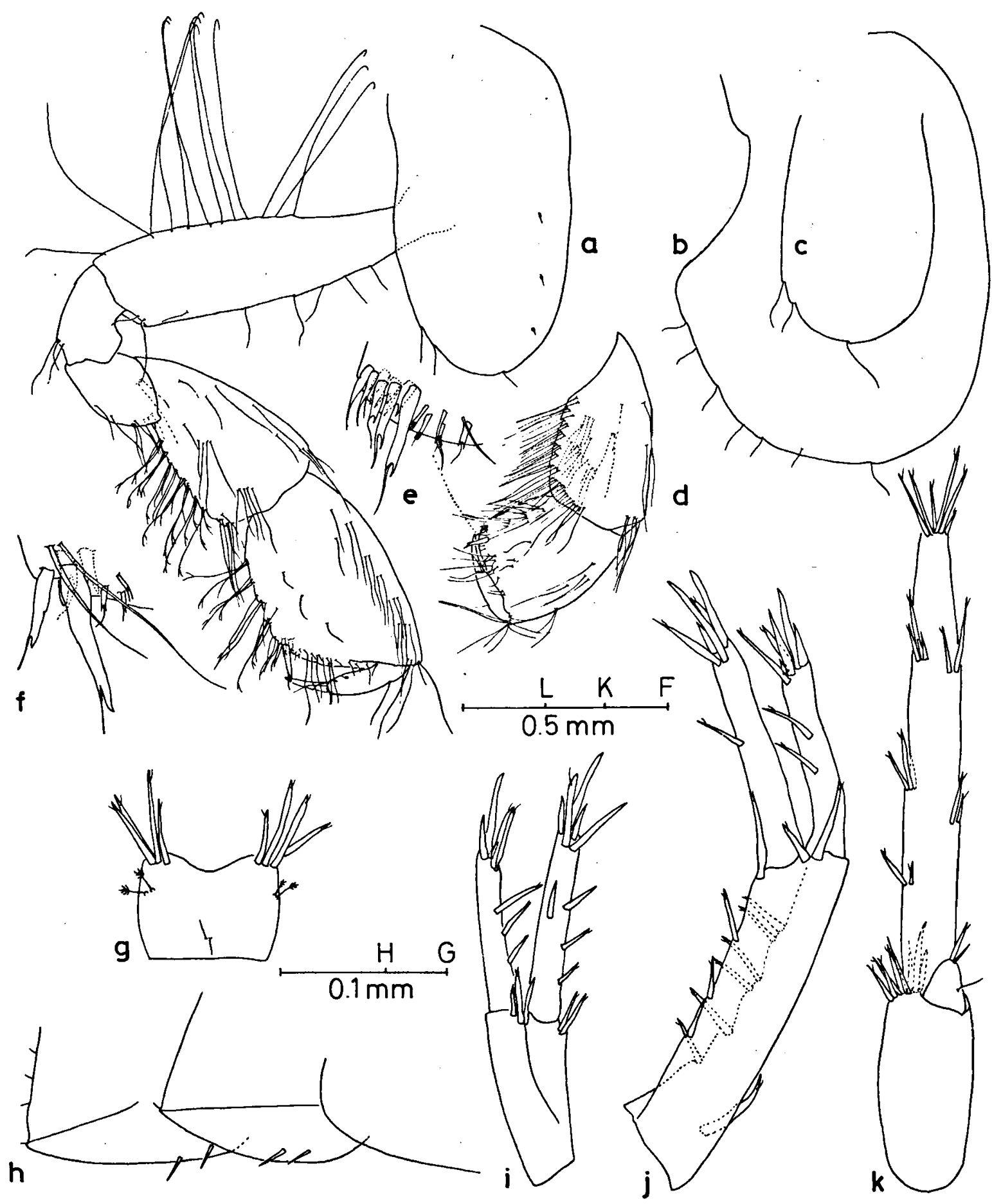

Fig. 3. Pseudoniphargus longicarpus n. sp. (holotype $\$ 6.5 \mathrm{~mm}$ from Río Sella near Fries): a, gnathopod 2 (scale F); b, coxal plate pereiopod 4 (F); c, coxal plate pereiopod 3 (F); d, distal part gnathopod 1 (F); e, palmar angle gnathopod 1 (G); f, palmar angle gnathopod 2 (G); g, telson (F); h, epimera (F); i, uropod 2 (F); j, uropod 1 (F); k, uropod 3 (F). 


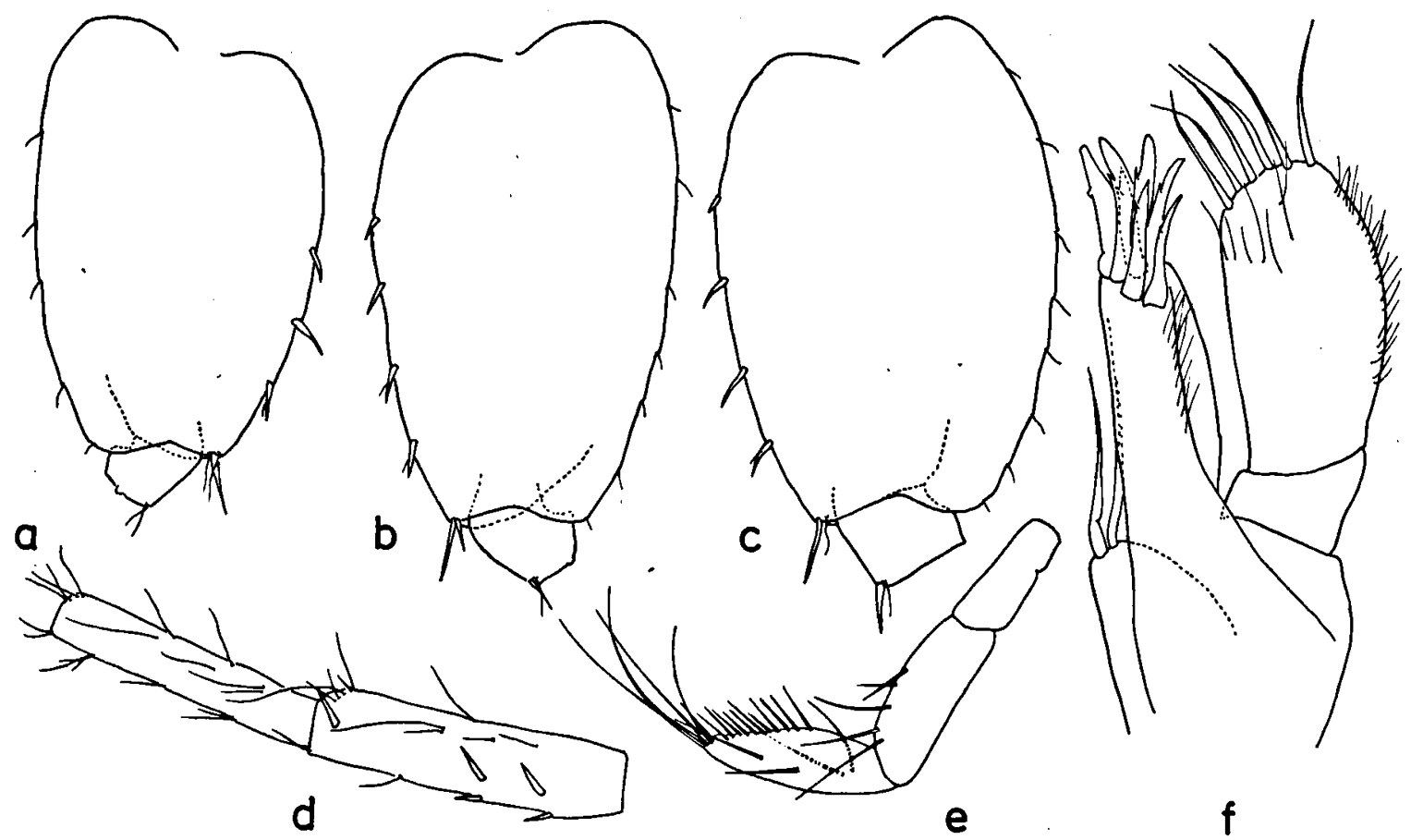

Fig. 4. Pseudoniphargus longicarpus n. sp. (holotype $96.5 \mathrm{~mm}$ from Río Sella near Fries): a, basis pereiopod 5 (scale A); b, basis pereiopod 6 (A); c, basis pereiopod 7 (A); d, peduncle segments 4 and 5 antenna 2 (B); e, mandible palp (A); f, maxilla $1(\mathrm{C})$.

marginal spines, terminal spines long. Uropod 2 (fig. 3i) with slender rami, armed with several marginal spines and long terminal spines. Uropod 3 (fig. $3 \mathrm{k}$ ): peduncle about twice as long as wide; exopodite 8-9 times as long as wide, margins armed with 2-3 groups of spines, each group with up to 4 spines, terminal spines somewhat longer than lateral spines.

Telson (fig. $3 \mathrm{~g}$ ) wider than long, with wide, shallow apical notch, and 4 terminal spines ( 2 in smaller specimens) on either side.

Male: only small individuals available. Compared with females of same size, less elongated gnathopodal carpus and more robust propodus of P2. No sexual differences found in U3. Because larger males are lacking it is impossible to find out if there is sexual dimorphism between fully developed males and females.

Remarks. - This species is mainly characterized by the elongated carpus of $\mathrm{P} 1$ and $\mathrm{P} 2$, and the moderate elongation in the exopodite of U3 (probably without sexual differences). In the latter character it resembles semielongatus. Moreover, longicarpus differs from semielongatus in the length of $\mathrm{A} 1, \mathrm{Mx} 1$, coxae, and basis of P5-P7.

Etymology. - The specific name longicarpus alludes to the strongly elongated carpus of the gnathopods.

Pseudoniphargus semielongatus n. sp. (Figs. 5-6)

Material examined. - Prov. Oviedo, Peñamellera Baja, Narganes, SBR Río Deva, UTM coordinates UN739993, alt. 5 m; 6 Nov. 1983 (sta. 83-11/6), 1 o holotype, 1 \& allotype, $1 \sigma^{\circ}$ intersex, $28 \sigma^{\circ} \sigma^{\circ}, 29$ $९$ and 19 juvs. (paratypes) (ZMA coll. no. Amph. 108.021).

Prov. Oviedo, Peñamellera Baja, Buelles, SBR Río Deva, UTM coordinates UN752995, alt. $15 \mathrm{~m} ; 7$ Oct. 1983 (sta. 83-10/3), 2 ơ $\sigma^{\prime}$ and 1 ovigerous $Q$.

Prov. Oviedo, Rivadedeva, La Haya, SBR Río Deva, UTM coordinates UP759022, alt. $5 \mathrm{~m}$; 6 Nov. 1983 (sta. 83-11/5), 1 \%, 6 우 and 5 juvs.

Prov. Oviedo, Peñamellera Baja, $3.5 \mathrm{~km} \mathrm{~S}$. of Panes, SBR Río Deva, UTM coordinates UN696949, alt. $45 \mathrm{~m}$; 
6 Nov. 1983 (sta. 83-11/7), 9 ơơ, 12 ९ (1 ovigerous) and 5 juvs.

Prov. Santander, Ruente, SBR La Fuentona (large resurgence), UTM coordinates UN975903, alt. $200 \mathrm{~m} ; 31$ Oct. 1983 (sta. 83-10/67), 4 ơ 6 \% 6 and 5 juvs.

Prov. Santander, Los Tojos, La Ponvieja, SKC Río Agouza or Río Lador, UTM coordinates UN985796, alt. $400 \mathrm{~m} ; 31$ Oct. 1983 (sta. 83-10/68), 9 o' $\sigma^{\circ}$ and 17 ९.

Prov. Santander, Ruiloba, Cueva del Portillo (near Comillas), UTM coordinates UP964047, alt. $20 \mathrm{~m} ; 17$ Feb. 1984 (sta. 84-2/46), in small phreatic lake with clayey bottom, 1 ơ, 5 ९ (1 ovigerous) and 2 juvs. (probably this species).

Description. - Largest males and females 6.5 and $5 \mathrm{~mm}$, respectively; ovigerous females ranging from 4.0 to $4.5 \mathrm{~mm}$.

Male: Antenna 1 little longer than half body length, peduncle segments scarcely armed with short setae, flagellum 18- to 20-segmented, aesthetascs $1 / 2-3 / 4$ of the length of the segments on which they are implanted. Antenna 2: peduncle longer than in $\mathrm{A} 1$, segments 4 and 5 armed with setae only.

Maxilla 1: outer lobe with 2 multidenticulate inner spines, other spines smooth or unidenticulate. Inner lobe of lower lip (fig. $5 \mathrm{~m}$ ) rather wide, almost as long as outer lobe. Mandibular palp (fig. 5i) segment 2 with several ventral setae, segment 3 with 1 A-seta, 1 B-seta, 9-14 $\mathrm{D}$-setae, and $3 \mathrm{E}$-setae. Other mouthparts without peculiarities.

Gnathopod 1 (fig. 5h): coxal plate (fig. 6i) rectangular with convex distal margin bearing 2 setae; carpus slightly shorter than propodus, posterior margin with 5 setal rows; propodus with 3 setal rows on posterior margin, palmar angle with 5 spines; unguis $1 / 3-1 / 2$ of dactylus length. Gnathopod 2 (fig. 5a): coxal plate rectangular, convex distal margin bearing 2 setae; carpus elongated with 4 setal rows on posterior margin; propodus rather strong, its posterior margin bears 4 setal rows; dactylus longer than 3/4 of palmar length, with short slender unguis.

Coxal plate of P3 (fig. 6a) rectangular with 2 distal setae; plate 4 (fig. 6f) with shallow posterior excavation and 4 distal setae.

Pereiopod 5 (fig. 6c): anterior margin of basis convex with 8 little spines, posterior margin straight, with 8-10 setules, posterior lobe wide, posterodistal angle overhanging. Pereiopod 6: basis (fig. 6d) longer and more tapering than in P5 and P7, anterior margin with 6 little spines, posterior margin straight, with 8-14 setules, posterior lobe wide, posterodistal angle slightly overhanging. Pereiopod 7: basis (fig. 6e) ovoid, anterior margin with 5 little spines, posterior margin with 10 setules, posterior lobe wide, posterodistal angle slightly overhanging. Claws not very slender, dactylus progressively more elongated from P5 to P7.

Epimeral plates 2 and 3 (figs. 5k, n), both with 1 spine on lower margin, posteroventral corner rectangular.

Uropod 1 (fig. 5c): slender peduncle with basoventral spine, 2 medial spines, dorsal row of 3-4 spines, distal spines not particularly long. Rami with no or few marginal spines, terminal spines short.

Uropod 2 (fig. $5 \mathrm{~g}$ ): peduncle with 1 or 2 dorsal spines, distal spines short; rami slender, marginally armed with $0-2$ spines, terminal spines short.

Uropod 3 (figs. 5e, f): peduncle twice as long as wide; exopodite 8-10 times as long as wide, margins with 4 or 5 spine groups, each group with 1 or 2 spines, terminal spines distinctly shorter than lateral spines.

Telson (fig. $5 \mathrm{j}$ ): wider than long; with $\mathrm{V}$ shaped distal notch; 2-3 subterminal spines on either side.

Female: Gnathopodal carpus and propodus somewhat smaller. Oostegites (fig. 5b) with 5-6 setae on distal part. Basis of P5 to P7 (figs. 6g, h) narrower and less elongated. Exopodite of U3 (fig. 5d) mostly little shorter than in male. Other characters (telson: see fig. 5-l) as in male.

Remarks. - A male intersex (6.5 $\mathrm{mm}$ ) from Río Deva near Narganes resembles in all characters a full-grown male, but possesses a nonsetose oostegite on $\mathrm{P} 4$.

By the structure of the third uropod this species resembles longicarpus. For differences between the two, see remarks under the latter species.

From the basin of the Río Saja (Río Agouza and La Fuentona) only a few small specimens 


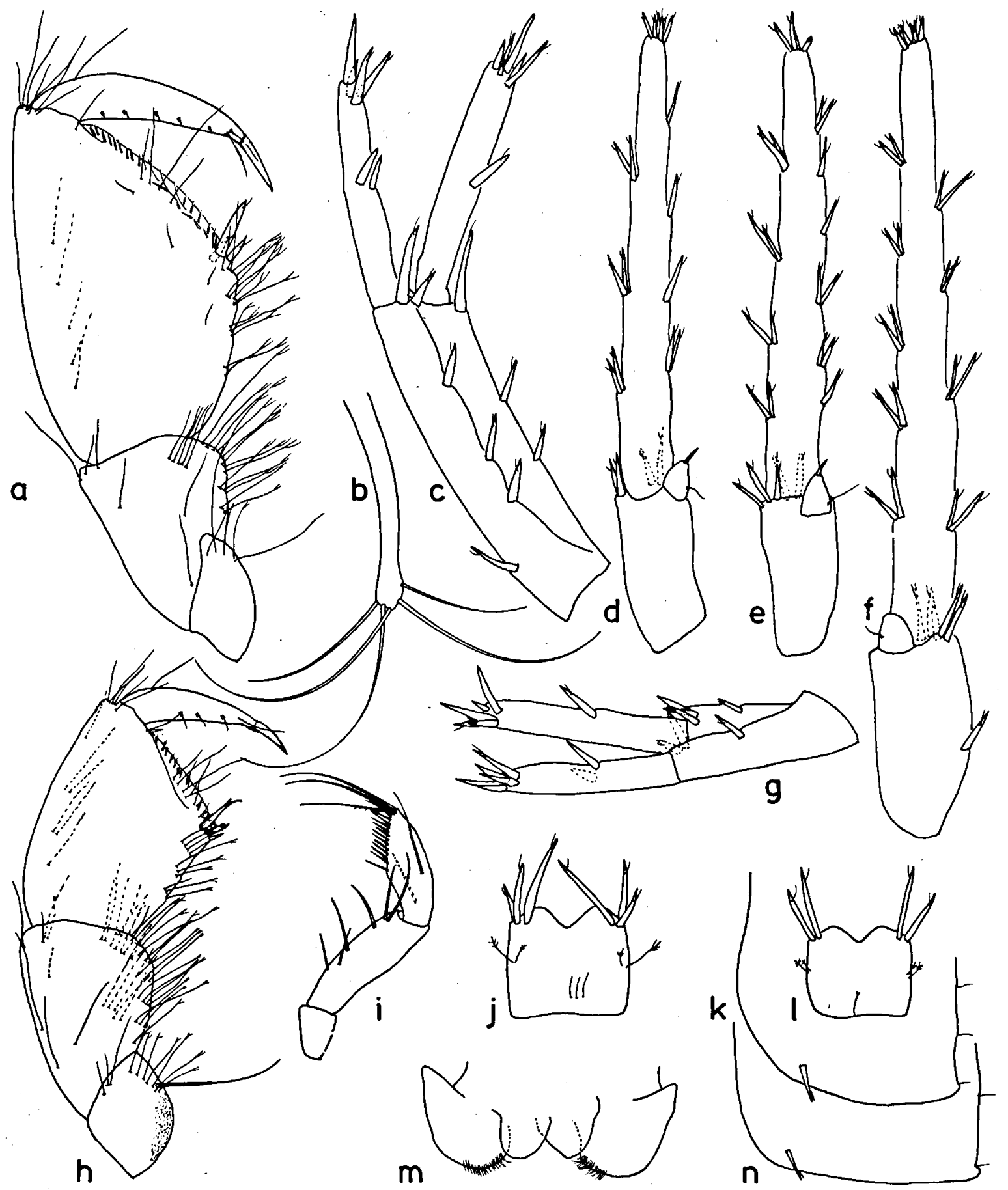

Fig. 5. Pseudoniphargus semielongatus n. sp. (a, c, e-j, $\sigma^{\circ}$ paratype $6.0 \mathrm{~mm}$; d, l, $\&$ paratype $5.0 \mathrm{~mm}$; b, $९$ paratype 5.5 $\mathrm{mm} ; \mathrm{m}, \sigma^{*}$ paratype $5.0 \mathrm{~mm} ; \mathrm{k}, \mathrm{n}, \sigma^{\circ}$ paratype $5.5 \mathrm{~mm}$, all from Río Deva near Narganes): a, gnathopod $20^{\circ}$ (scale A); b, oostegite pereiopod 3 \& (A); c, uropod $10^{\circ}$ (A); d, uropod 3 \& (A); e, uropod $3 \sigma^{\circ}$ right (A); f, uropod $3 \sigma^{\circ}$ left (A); g, uropod $20^{\circ}(\mathrm{A}) ; \mathrm{h}$, gnathopod $1 \sigma^{\circ}(\mathrm{A}) ; \mathrm{i}$, mandible palp $\sigma^{\circ}$ (A); j, telson $\sigma^{\circ}$ (A); k, epimera $2 \sigma^{\circ}$ (B); 1 , telson $\%$ (A); $\mathrm{m}$, lower lip $\sigma^{\circ}(\mathrm{A}) ; \mathrm{n}$, epimera $3 \sigma^{\circ}(\mathrm{B})$. 


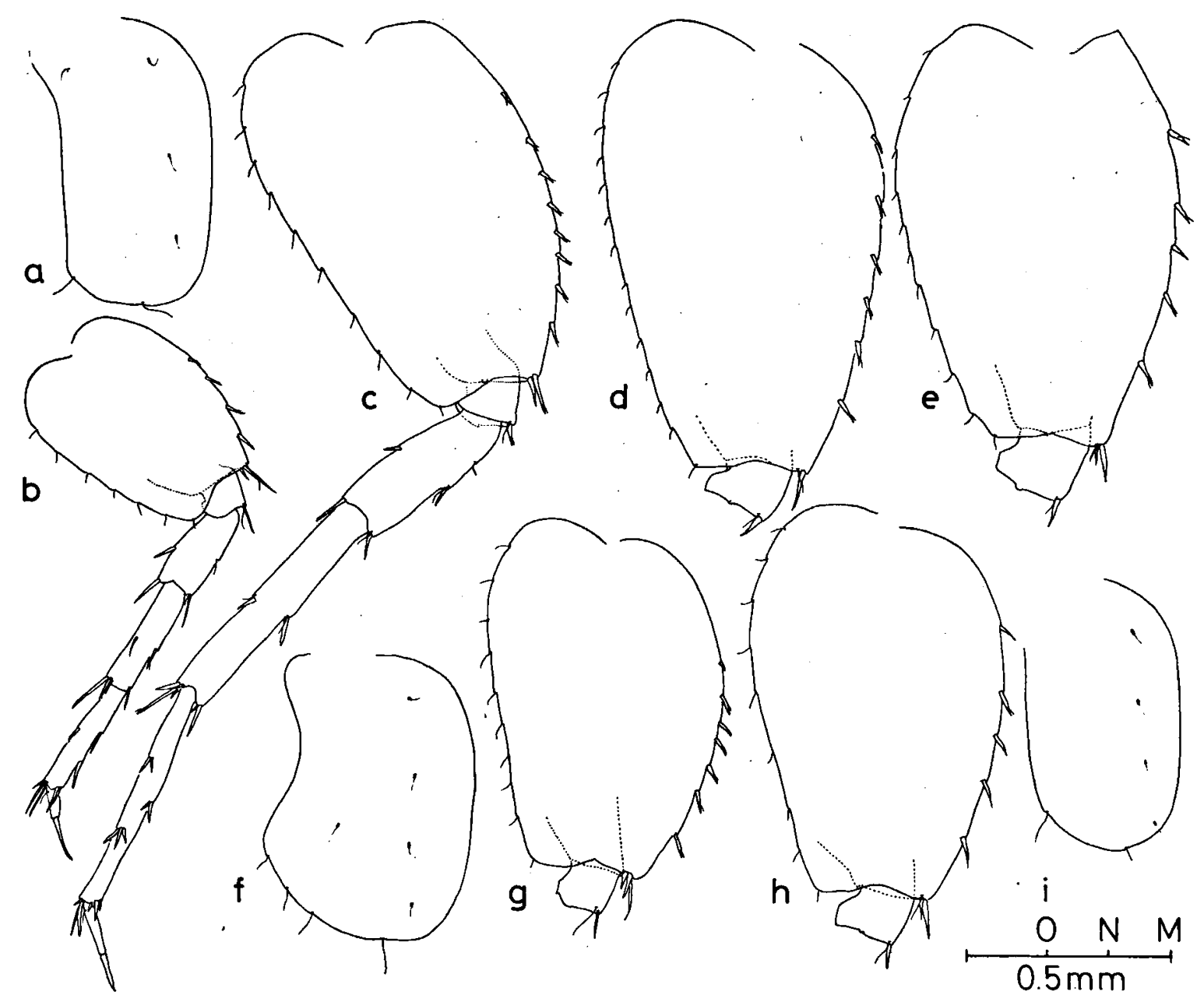

Fig. 6. Pseudoniphargus semielongatus n. sp. (a, c-f, i, o paratype $6.0 \mathrm{~mm} ; \mathrm{g}, \mathrm{h}$, $\$$ paratype $5.0 \mathrm{~mm}$, both from Río Deva near Narganes; b, o $3.2 \mathrm{~mm}$ from Cueva de Portillo): a, coxal plate pereiopod $3 \sigma^{\circ}$ (scale M); b, pereiopod 5 o (M); c, pereiopod $5 \sigma^{\circ}(\mathrm{M})$; d, basis pereiopod $6 \sigma^{\circ}(\mathrm{M})$; e, basis pereiopod $7 \sigma^{\circ}(\mathrm{M})$; f, coxal plate pereiopod $4 \sigma^{\circ}(\mathrm{M})$; $\mathrm{g}$, basis pereiopod 5 \% (M); h, basis pereiopod 6 \% (M); i, coxal plate gnathopod $2 \sigma^{\circ}(\mathrm{M})$.

are available. These specimens show small morphological differences with specimens from the Río Deva: peduncle segment 4 of A1 with several spines; basis of P5-P7 with more rounded margin and more overhanging posterodistal angle; exopodite of U3 somewhat less elongated and sometimes with 3 spines in each lateral group. Some of these differences are probably due to the fact that the Saja specimens are not fully developed, other differences may be interpreted as intraspecific variations.
The animals from Cueva del Portillo are classified with this species with some doubt. They have relatively short antennae, pereiopods 3 to 7 with an elongated unguis, and a rather wide basis of $\mathrm{P} 5$ to $\mathrm{P} 7$, with a strongly overhanging posterodistal angle (fig. 6b).

Etymology. - The specific name semielongatus alludes to the slight elongation of both pedunculus and exopodite of uropod 3 , which is less strong than in elongatus. 
Pseudoniphargus montanus n. sp.

(Figs. 7-8)

Material examined. - Prov. Léon, Riaño, Huelde, SBR Río Esla, UTM coordinates UN308563, alt. 1050 m; 20 Oct. 1983 (sta. 83-10/39), 1 o holotype, 1 \& allotype, 92 \&ᄋ (1 ovigerous), $680^{\circ} \sigma^{\circ}$ and 11 juvs. (paratypes) (ZMA coll. no. Amph. 107.972).

Prov. Oviedo, Cangas de Onis, Tornin, SBR Río Sella, UTM coordinates UN274989, alt. 90 m; 9 Oct. 1983 (sta. 83-10/7), 22 ○๐, 44 ९ᄋ and 20 juvs.

Prov. León, Oseja de Sajambre, Ribota, SKC Río Sella, UTM coordinates UN334786, alt. $550 \mathrm{~m} ; 9$ Oct. 1983 (sta. 83-10/8), 2 ○॰ 7 ㅇ \& and 6 juvs.

Prov. León, Rodiezmo, Villanueva de la Tercia, SBR Río Bernesga, UTM coordinates TN823607, alt. $1150 \mathrm{~m}$; 19 Oct. 1983 (sta. 83-10/32), 2 ơ $0^{\circ}, 6$ 우 and 4 juvs.

Prov. León, Cármenes, Felmin, SBR Río Torio, UTM coordinates TN926546, alt. 1090 m; 19 Oct. 1983 (sta. 83-10/33), 37 O’$^{\circ}, 63$ 우 and 6 juvs.

Prov. León, well at Matallana de Torio, UTM coordinates TN942494, alt. 1050 m; 19 Oct. 1983 (sta. 8310/34), 1 ơ.

Prov. León, Valdepielago, Montuerto, SBR Río Curueño, UTM coordinates UN045509, alt. $1000 \mathrm{~m} ; 19$ Oct. 1983 (sta. 83-10/35), 55 ơơ, 53 ㅇ and 67 juvs.

Prov. León, Villayandre, SBR Río Esla, UTM coordinates UN237510, alt. $950 \mathrm{~m} ; 20$ Oct. 1983 (sta. 8310/38), 23 ơ, 29 우 and 7 juvs.

Prov. León, Vegacerneja, SBR tributary of the Río Esla, UTM coordinates UN337673, alt. 1075 m; 20 Oct. 1983 (sta. 83-10/40), 10 ơ 0 , 6 \% $\$$ and 7 juvs.

Prov. Oviedo, Amieva, Vega de Sella, SBR Río Sella, UTM coordinates UN293906, alt. $250 \mathrm{~m} ; 21$ Oct. 1983 (sta. 83-10/43), 1 juv. (probably this species).

Prov. León, Portilla de la Reina, SKC Río Yuso, about $3 \mathrm{~km} \mathrm{S.W.} \mathrm{of} \mathrm{P.} \mathrm{de} \mathrm{la} \mathrm{Reina,} \mathrm{UTM} \mathrm{coordinates}$ UN479647, alt. $1200 \mathrm{~m}$; 8 Nov. 1983 (sta. 83-11/15), 12 $0^{\circ} \circ, 41 \% Q$ and 8 juvs.

Description. - Males up to $6.2 \mathrm{~mm}$, females up to $7.5 \mathrm{~mm}$.

Male: Antenna 1 (fig. 7q): somewhat longer than half the body length; peduncle sparsely armed with short setae; flagellum with 18-21 segments, aesthetascs $1 / 2-3 / 4$ of the length of the segments on which they are implanted. Antenna 2 (fig. 7r): peduncle little longer than peduncle of $A 1$, segments 4 and 5 armed with numerous short setae, segment 4 bearing several spines; flagellum 7- to 8-segmented.

Mandible palp (fig. 7b): segment 2 with few spines on ventral margin, segment 3 with 1-2 A-setae, 1-2 B-setae, 11-14 D-setae and $3 \mathrm{E}$ - setae. Outer lobe of maxilla 1 with $4(-5)$ multidenticulate spines. Other mouthparts without peculiarities.

Gnathopod 1: convex distal margin of coxal plate (fig. 7e) with 3 setae; carpus and propodus (fig. $7 \mathrm{~g}$ ) of equal length, carpus with 4-5 rows of setae on posterior margin; posterior margin of propodus with 3 setal groups, 5-7 palmar angle (fig. 7f) spines. Gnathopod 2: convex lower margin of coxa (fig. 7d) armed with 3-4 setae; carpus elongated, posterior margin with 4 setal rows; propodus wide, posterior margin with 3-4 setal groups (fig. 7a); unguis slender, about $1 / 3$ of length of dactylus.

Pereiopod 3: coxal plate (fig. 8d) narrow, ovoid, with 3 distal setae. Pereiopod 4: coxal plate (fig. 8e) wide, with well-developed posterior excavation, and 2-4 distal setae. Claws of P3-P7 not elongated.

Basis of P5 (fig. 8a) and P6 (fig. 8b) slender, of P7 (fig. 8c) rather wide; basis of P6 longer than that of $\mathrm{P} 5$ and $\mathrm{P} 7$; posterior lobes rather narrow, posterodistal angles overhanging. P5 with 5-7 little spines on anterior margin, and 710 setules posteriorly; P6 with 5-7 little spines anteriorly and 8-10 setules posteriorly; P7 with 4-5 little spines on anterior margin and posteriorly 8-9 setules.

Epimera 2 and 3 (figs. 7-o, p) each with 1 spine on lower margin, posteroventral corner acute, with small tooth; posterior margin scarcely armed.

Uropod 1 (figs. $8 \mathrm{~m}$, o): peduncle with long and curved basoventral spine, 1 or 2 medial spines, dorsal row of 3-4 spines, and slender distal spines; rami short, sometimes with some marginal spines, apical spines slender. Uropod 2 (figs. 8-1, n): peduncle with 1 dorsal spine, distal spines short; rami with several marginal spines. Uropod 3 (figs. 8f, j): peduncle about 1.5 times as long as wide; exopodite 6-7 times as long as wide, margins armed with 2-4 spine groups, each group with up to 3 spines, terminal spines little shorter than lateral spines.

Telson (figs. $7 \mathrm{~h}, \mathrm{j}, \mathrm{k}$ ) wider than long, apical notch very shallow or absent, 3 terminal spines on either side. 


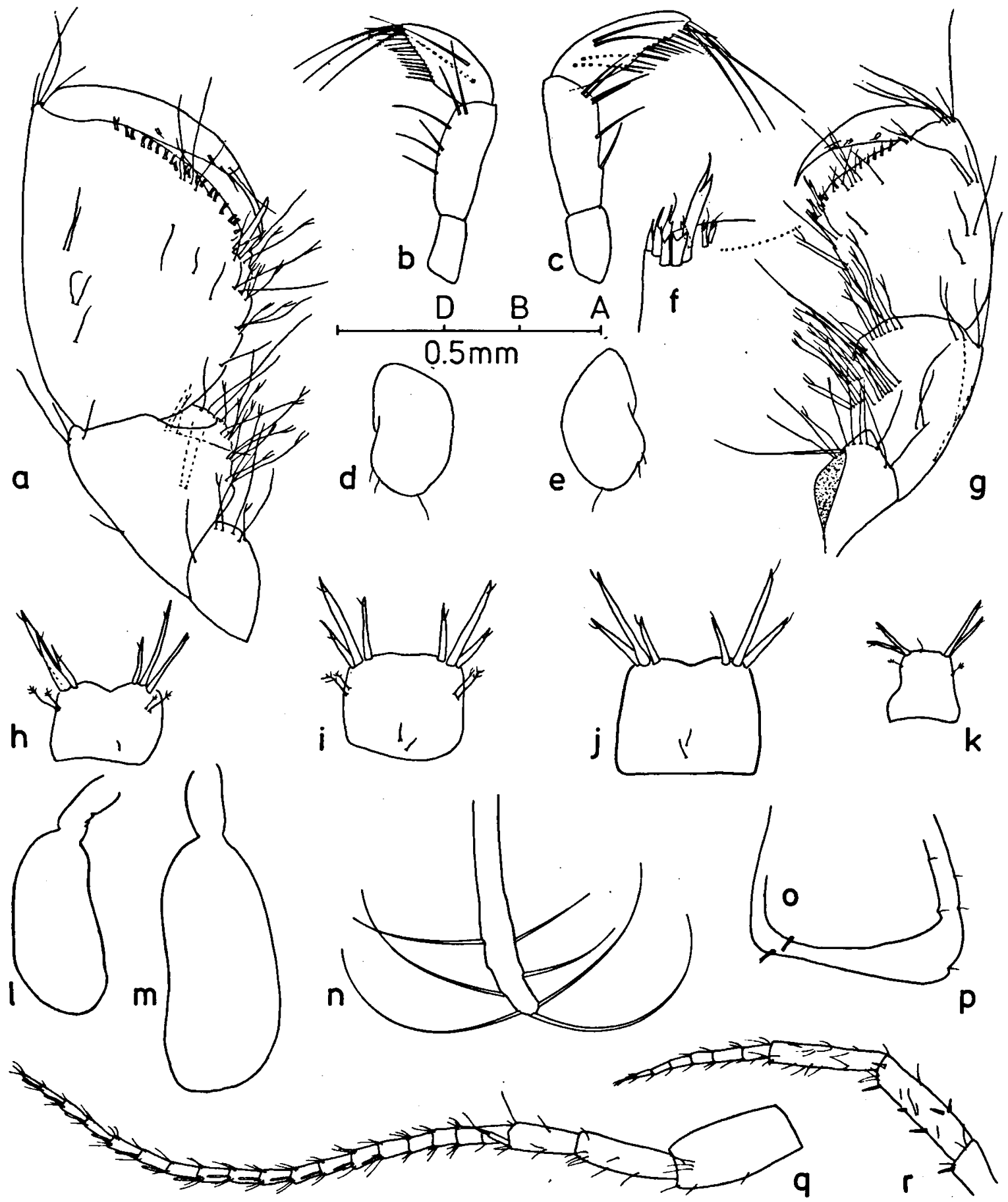

Fig. 7. Pseudoniphargus montanus n. sp. (a, b, d-h, q, r, ơ paratype $6.2 \mathrm{~mm}$; c, i, l-n, 9 paratype $7.5 \mathrm{~mm}$, both from Río Esla near Huelde; j, ơ 6.0 mm from Río Esla near Villayandre; k, o, p, ơ $5.0 \mathrm{~mm}$ from Río Sella near Tornin): a, gnathopod $2 \sigma^{\circ}$ (scale A); b, mandible palp $\sigma^{\circ}$ (A); c, mandible palp $Q$ (A); d, coxal plate gnathopod $2 \sigma^{\circ}$ (D); e, coxal plate gnathopod $10^{\circ}$ (D); f, palmar angle gnathopod $1 \sigma^{\circ}$ (A); g, gnathopod $1 \sigma^{\circ}$ (A); h, telson $\sigma^{\circ}$ (A); i, telson \& (A); j, telson $\sigma^{\prime}(\mathrm{A}) ; \mathrm{k}$, telson, $\sigma^{\prime}(\mathrm{A}) ; 1$, gill pereiopod 2 \% (B); $\mathrm{m}$, gill pereiopod 3 \& (B); n, oostegite pereiopod 3 (B); o, epimera $2 \sigma^{\circ}(\mathrm{B})$; p, epimera $3 \sigma^{\circ}(\mathrm{B})$; $\mathrm{q}$, antenna $1 \sigma(\mathrm{A})$; $\mathrm{r}$, antenna $2 \sigma^{\circ}(\mathrm{A})$. 


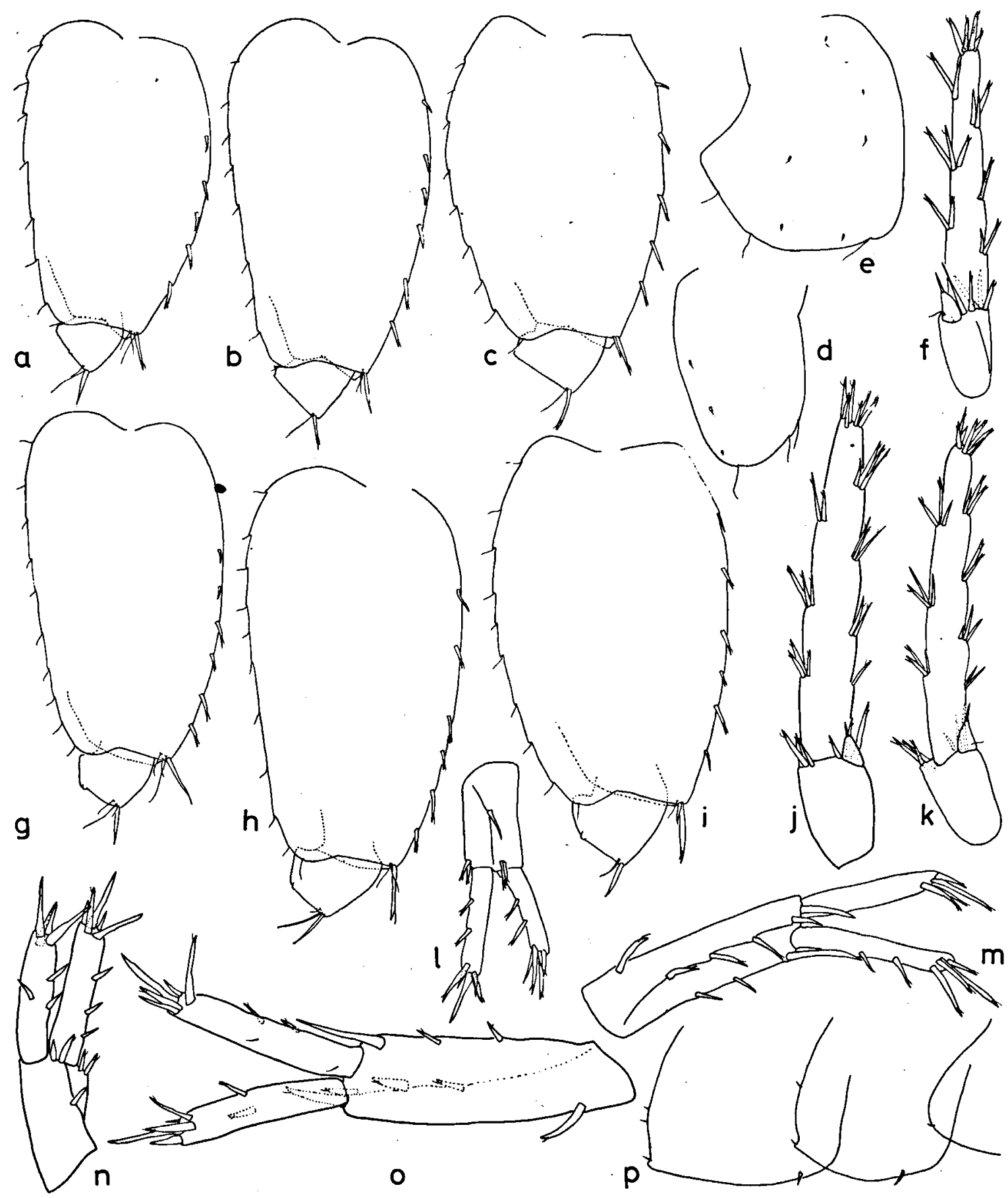

Fig. 8. Pseudoniphargus montanus n. sp. (a-f, l, m, $\sigma^{\circ}$ paratype $6.2 \mathrm{~mm} ; \mathrm{g}-\mathrm{i}, \mathrm{k}$, $\%$ paratype $7.5 \mathrm{~mm}$, both from Río Esla near Huelde; j, n-p, $\sigma^{*} 6.2 \mathrm{~mm}$ from Río Esla near Villayandre): a, basis pereiopod $5 \sigma^{\circ}$ (scale M); b, basis pereiopod $6 \sigma^{\circ}(\mathrm{M})$; c, basis pereiopod $7 \sigma^{\circ}(\mathrm{M})$; d, coxal plate pereiopod $30^{\circ}(\mathrm{M})$; e, coxal plate pereiopod $4 \sigma^{\circ}(\mathrm{M})$; f, uropod $3 \sigma^{\circ}(\mathrm{M}) ; \mathrm{g}$, basis pereiopod 5 \% (M); h, basis pereiopod 6 \& (M); i, basis pereiopod 7 \& (M); j, uropod $3 \circ(\mathrm{M})$; k, uropod 3 \& (M); l, uropod $2 \sigma^{\circ}(\mathrm{M}) ; \mathrm{m}$, uropod $1 \sigma^{\circ}(\mathrm{M}) ; \mathrm{n}$, uropod $2 \sigma^{\circ}(\mathrm{M})$; o, uropod $1 \sigma^{\circ}(\mathrm{M})$; p, epimera $\sigma^{\circ}(\mathrm{N})$. 
Female: Like male. Oostegites (fig. 7n) with 5-8 setae. Figured are mandible palp (fig. 7c), telson (fig. 7i), gill of pereiopods 2 and 3 (figs. $7-1, \mathrm{~m}$ ), basis of pereiopods 5 to 7 (figs. $8 \mathrm{~g}, \mathrm{~h}$, i), and uropod 3 (fig. 8k).

Remarks. - Very small morphological differences are found between the different populations of this species. It is closely related to semielongatus, but differs from it mainly in the morphology of coxae 3 and 4, basis of P5-P7, and U3.

Etymology. - The proposed specific name montanus alludes to the high altitudes $(1000 \mathrm{~m}$ and more) of the majority of the localities in which this species has been found.

\section{Pseudoniphargus elongatus Stock, 1980 (Figs. 9-10)}

Stock, 1980: 137-140, figs. 23-25.

Material examined. - Prov. Santander, Ramales de la Victoria, Cueva la Cullevera; 22 July 1979, in shallow pool, $\sigma$ holotype and ovigerous $\$$ allotype; leg. J. H., M. D. Stock (ZMA coll. no. Amph. 107.333).

Prov. Santander, Cueva la Cascada; 6 Aug. 1962; 1 \& paratype (microscopical slides only) (ZMA coll. no. Amph. 107.348),leg. De Loriol.

Prov. Santander, Reocín, Cueva de la Estación de Santa Isabel, UTM coordinates VP100014, alt. $60 \mathrm{~m} ; 8$ Oct. 1936, 9 paratype (microscopical slides only); leg. $\mathbf{H}$. J. Stammer (ZMA coll. no. Amph. 107.349).

Prov. Santander, Soba, La Gándara, Cueva Becerral (above the rising of the Río Gándara), UTM coordinates VN526827, alt. $800 \mathrm{~m} ; 12$ Oct. 1983 (sta. 83-10/10), in water trickle, 7 ơ, 6 $\%$ and 3 juvs.

Prov. Santander, Vega de Pas, Yera, SBR Río Yera, UTM coordinates VN379770, alt. 475 m; 25 Oct. 1983 (sta. 83-10/48), 1 o, 3 \&Q and 3 juvs.

Prov. Burgos, Espinosa de los Monteros, caught karst spring at Trueba, UTM coordinates VN457740, alt. 1100 m; 25 Oct. 1985 (sta. 83-10/49), 1 \&.

Prov. Burgos, Merindad de Montija, El Ribero, SBR Río Cerneja, UTM coordinates VN608656, alt. $675 \mathrm{~m}$; 26 Oct. 1983 (sta. 83-10/52), 3 ơ

Prov. Santander, Arredondo, Val de Asón, SBR in the resurgence of the Cueva la Cubera, UTM coordinates VN511895, alt. $200 \mathrm{~m}$; 26 Oct. 1983 (sta. 83-10/57), 24 ○ัo, 53 ९९ (1 ovigerous) and 10 juvs.; 19 Nov. 1983 (sta. 83-11/33), 1 \%.

Prov. Santander, Arredondo, SBR Río Asón, UTM coordinates VN518912, alt. $170 \mathrm{~m} ; 27$ Oct. 1983 (sta. 8310/59), 3 ơ and 4 우.
Prov. Santander, Entrambasaguas, San Antonio, SKC Río Aguanaz, UTM coordinates VP469023, alt. 60 m; 28 Nov. 1983 (sta. 83-10/66), 1 ovigerous. (damaged) and 1 juv. (probably this species).

Prov. Santander, Entrambasaguas, Hoznayo, Cueva de Recueva (rising of the Río Recueva), UTM coordinates VP435057, alt. 30 m; 4 Nov. 1983 (sta. 83-11/3), in water-filled gallery upstream of rimstone bar, 9 o ${ }^{\circ}$, $14 \%$ \% and 26 juvs.

Prov. Santander, Arredondo, Val de Asón, Cueva de Coventosa (large cave system with different aquatic biotopes), UTM coordinates VN508893, alt. $280 \mathrm{~m} ; 19$ Nov. 1983 (sta. 83-11/34), in large rimstone pool above the river level, $1 \sigma^{\circ}$ and $3 \circ \%$; in the main stream, $1 \sigma^{\circ}$, $1 \&$ and 1 juv.; 12 Feb. 1984 (sta. 84-2/37), in the main stream, 3 ơ ${ }^{\circ} 12$ July 1984 (sta. 84-7/11), in the main stream, 2 \& $Q$.

Prov. Santander, Miera, Mortesante, Cueva de la Carretera or Fuente Encalada (small resurgence cave), UTM coordinates VN428958, alt. 200 m; 20 Nov. 1983 (sta. 83 $11 / 36$ ), in brooklet running between boulders and stones, $60^{\circ} \circ, 25 \%$ and about 40 juvs.

Prov. Santander, Rasines, Cueva del Valle or Red del Silencio, resurgence cave, UTM coordinates VN659948, alt. $80 \mathrm{~m}$; 3 Dec. 1983 (sta. 83-12/4), in large pools near the entrance, 7 \% ${ }^{\circ}$ and 16 \& $Q$ (1 ovigerous); 19 Feb. 1984 (sta. 84-2/48), in the main stream, $1 \sigma^{\circ}$.

Prov. Santander, Miera, Mirones, Cueva de Fuente Fria or Fuente Rebolla, UTM coordinates VN433944, alt. $160 \mathrm{~m}$; 27 Dec. 1983 (sta. 83-12/7), in deep water between boulders near the entrance, 2 juvs.

Prov. Santander, Miera, Mirones, two small caves on the east slope of the Río Miera, UTM coordinates VN430954, alt. $250 \mathrm{~m} ; 27$ Dec. 1983 (sta. 83-12/8), in drip and seep pools, $40^{\circ} 0^{\circ}$ and $13 \%$ \&

Prov. Santander, Miera, Mirones, Manantial El Rescaño or Fuente del Pozo Cotirio (inaccessible resurgence), UTM coordinates VN434942, alt. $170 \mathrm{~m} ; 27$ Dec. 1983 (sta. 83-12/9), in stagnant water between boulders, $1 \sigma^{\circ}, 1 \%$ and 9 juvs.

Prov. Santander, Miera, Linto, Cueva del Sapo, UTM coordinates VN432906, alt. 500 m; 28 Dec. 1983 (sta. 83 $12 / 11$ ), in shallow dripwater pools, 3 \& .

Prov. Santander, Miera, Linto, Cueva Salitre, UTM coordinates VN432905, alt. 500 m; 2 Jan. 1984 (sta. 841/1), in dripwater pools, $110^{\circ} \sigma^{\circ}$ and 9 \% $\%$.

Prov. Santander, Ampuero, La Aparecida, Cueva Honda, UTM coordinates VN638977, alt. $200 \mathrm{~m}$; 2 Jan. 1984 (sta. 84-1/2), in a rimstone pool in dry riverbed, 2 ơ 0 and $5 \%$ \% 18 Feb. 1984 (sta. 84-2/47), in dripwater pools, $2 \sigma^{\circ} \sigma^{\prime}$ and 7 \% ( 1 ovigerous), and in brooklet, 2 오.

Prov. Santander, Matienzo, La Vega, Cueva del Comediante, UTM coordinates VN507957, alt. $170 \mathrm{~m} ; 25$ Feb. 1984 (sta. 84-2/52), in drip and seep pools, $120^{\circ} \sigma^{\circ}$, $14 \% \varnothing$ and 1 juv.

Prov. Santander, Matienzo, Ozana, small resurgence cave Jivero 1, UTM coordinates VN537948, alt. $260 \mathrm{~m}$; 
26 Feb. 1984 (sta. 84-2/55), in slowly running stream, 10 .

Prov. Santander, Matienzo, Ozana, Cueva del Orillón, UTM coordinates VN543947, alt. 275 m; 26 Feb. 1984 (sta. 84-2/57), in small stream, $580^{\circ} \sigma^{\prime}$ and more than 100 \&ᄋ (1 ovigerous).

Prov. Burgos, Merindad de Sotoscueva, SBR in the Manantial de Quintanilla de Valdebodres, UTM coordinates VN456602, alt. 700 m; 7 Apr. 1984 (sta. 84-4/11), 1 damaged $\sigma^{\circ}$ and part of a specimen.

Prov. Santander, Matienzo, La Vega, Cueva Cuvio de la Renada, UTM coordinates VN504957, alt. 180 m; 22 Apr. 1984 (sta. 84-4/29), in small stream, drip and seep pools, 3 ơo', 6 우 (1 ovigerous) and 5 juvs.

Prov. Santander, Arredondo, Bustablado, Cueva de Cañuela, UTM coordinates VN498918, alt. $300 \mathrm{~m} ; 11$ July 1984 (sta. 84-7/10), in drip and seep pools, $1 \sigma^{\circ}, 9$ \& ( 3 ovigerous) and 13 juvs.

Prov. Santander, Arredondo, Val de Asón, Cueva Fresca, UTM coordinates VN5185, alt. $400 \mathrm{~m} ; 17$ Aug. 1984 (sta. 84-8/10), in drip and seep pools, $20^{\circ} \sigma^{\circ}$ and $1 \%$.

Prov. Santander, Castañeda, well S. of barrio San Juan, UTM coordinates VN227950, alt. $40 \mathrm{~m}$; 26 Aug. 1984 (sta. 84-8/12), 18 O’ $^{\circ}$ and 17 ९ (dead specimens only!).

Prov. Santander, Castañeda, other well S. of barrio San Juan, UTM coordinates VN227950, alt. $40 \mathrm{~m}$; 26 Aug. 1984 (sta. 84-8/14), 1 \%, 2 우 and 3 juvs.

Descriptive notes, supplementing Stock's description. - Maximum length of males 7.5 $\mathrm{mm}$; ovigerous females are $3-5 \mathrm{~mm}$.
Male: Antenna 1 in large specimens little shorter than total body length; flagellum with up to 24 segments.

Mandible palp: segment 2 with several distoventral setae, segment 3 with 1 A-seta, 1-2 B-setae, 10-19 D-setae, and 3 E-setae. Maxilla 1: outer lobe with 3 multidenticulate spines.

Gnathopod 1 (fig. 9a): coxa short and rather wide, with 2 distal setae; carpus and propodus about equal in length; larger specimens with 6 rows of setae on posterior carpal margin and 2 rows on posterior margin of propodus; unguis about half the length of dactylus. Gnathopod 2 (fig. 9g): coxa rectangular, convex distal margin with 2 setae; carpus of larger specimens slightly elongated with up to 5 rows of setae on posterior margin; propodus with maximum of 5 rows of setae on posterior margin; unguis short, 1/4-1/3 of length of dactylus.

Claws of P3-P7 not elongated. Pereiopod 3: coxa (fig. $10 \mathrm{~g}$ ) rectangular, with 2 distal setae. Pereiopod 4: coxa (fig. 10h) relatively short with shallow posterior excavation, lower margin with 4-5 setae.

In general, basis of P5-P7 getting larger and more elongate in fully developed males; posterior margin of basis in larger males with 11 to

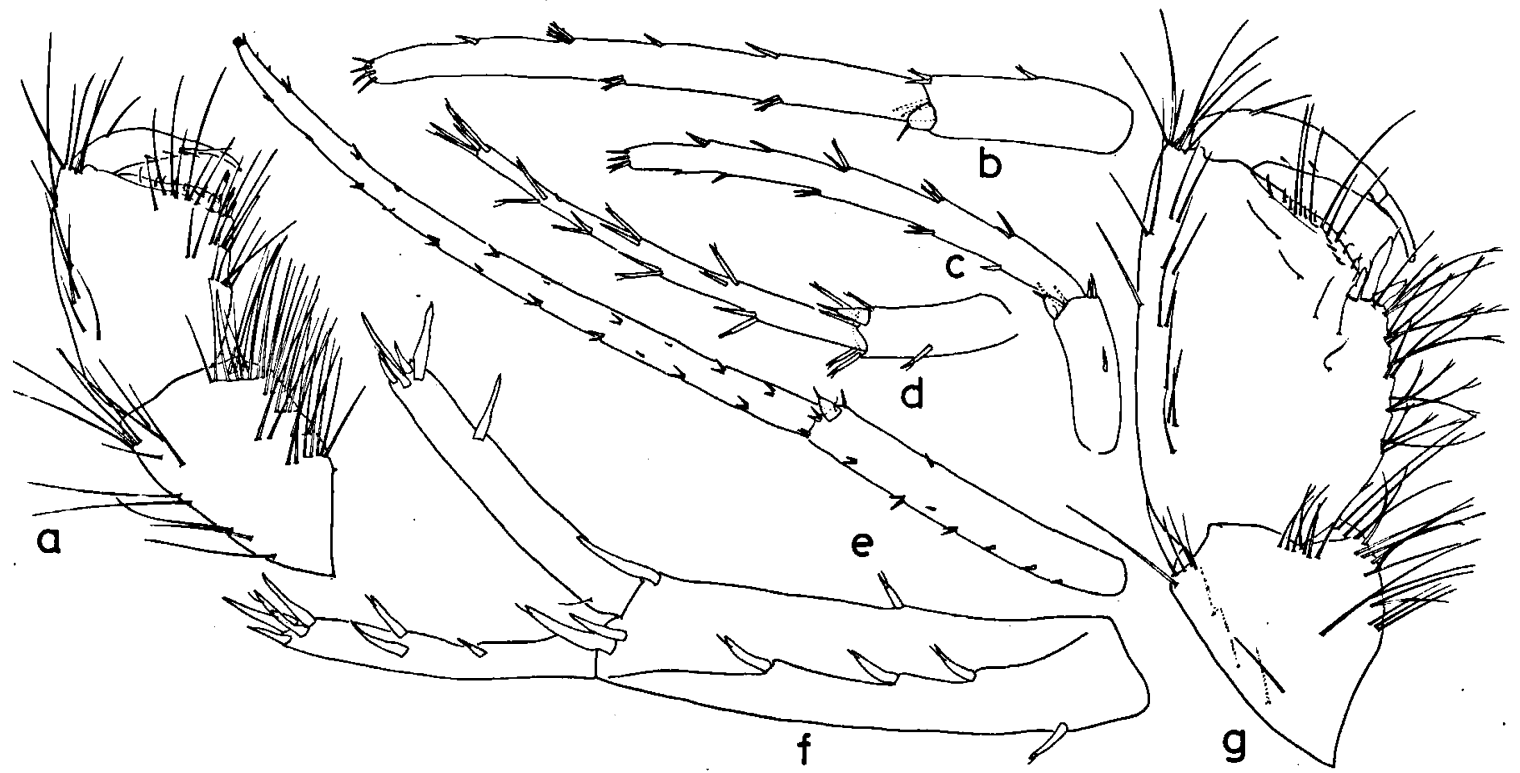

Fig. 9. Pseudoniphargus elongatus Stock, 1980 (a, e-g, $07.5 \mathrm{~mm}$ from Cueva de Coventosa; b, $\$$ from Cueva de la Cascada; c, $\sigma 2.6 \mathrm{~mm}$ from La Cubera; d, $\$ 5.4 \mathrm{~mm}$ from Cueva del Orillón): a, gnathopod $1 \sigma^{\circ}$ (scale M); b, uropod

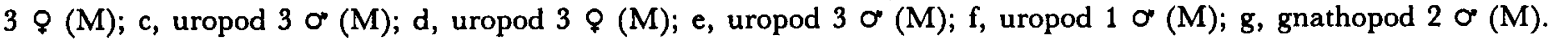


13 setules, posterior lobe wide. Pereiopod 5: weakly overhanging posterodistal angle of basis (fig. 10c). Pereiopods 6 and 7 with overhanging posterodistal angle (figs. 10a, b).

Uropod 1 (fig. 9f): " peduncle slender, basoventral spine present, medially 1 spine (sometimes lacking). Uropod 2: peduncle sometimes with 1 dorsal spine. Margins of rami of $\mathrm{U} 1$ and U2 occasionally armed. Spines on U1 and U2 usually relatively longer in smaller. specimens than in larger ones. Uropod 3 (figs. 9e, c): small specimens of both sexes (in which peduncle and exopodite are still not markedly elongated) bear relatively long marginal and terminal spines on exopodite. When the animal gets larger, peduncle and exopodite elongate while the spines are becoming shorter. Exopodite of adult males with setules and several marginal groups of short spines, each group consisting of 1 or 2 spines. In largest males (7.5 $\mathrm{mm}$ ), peduncle 8 times as long as wide, exopodite 17 times as long as wide.

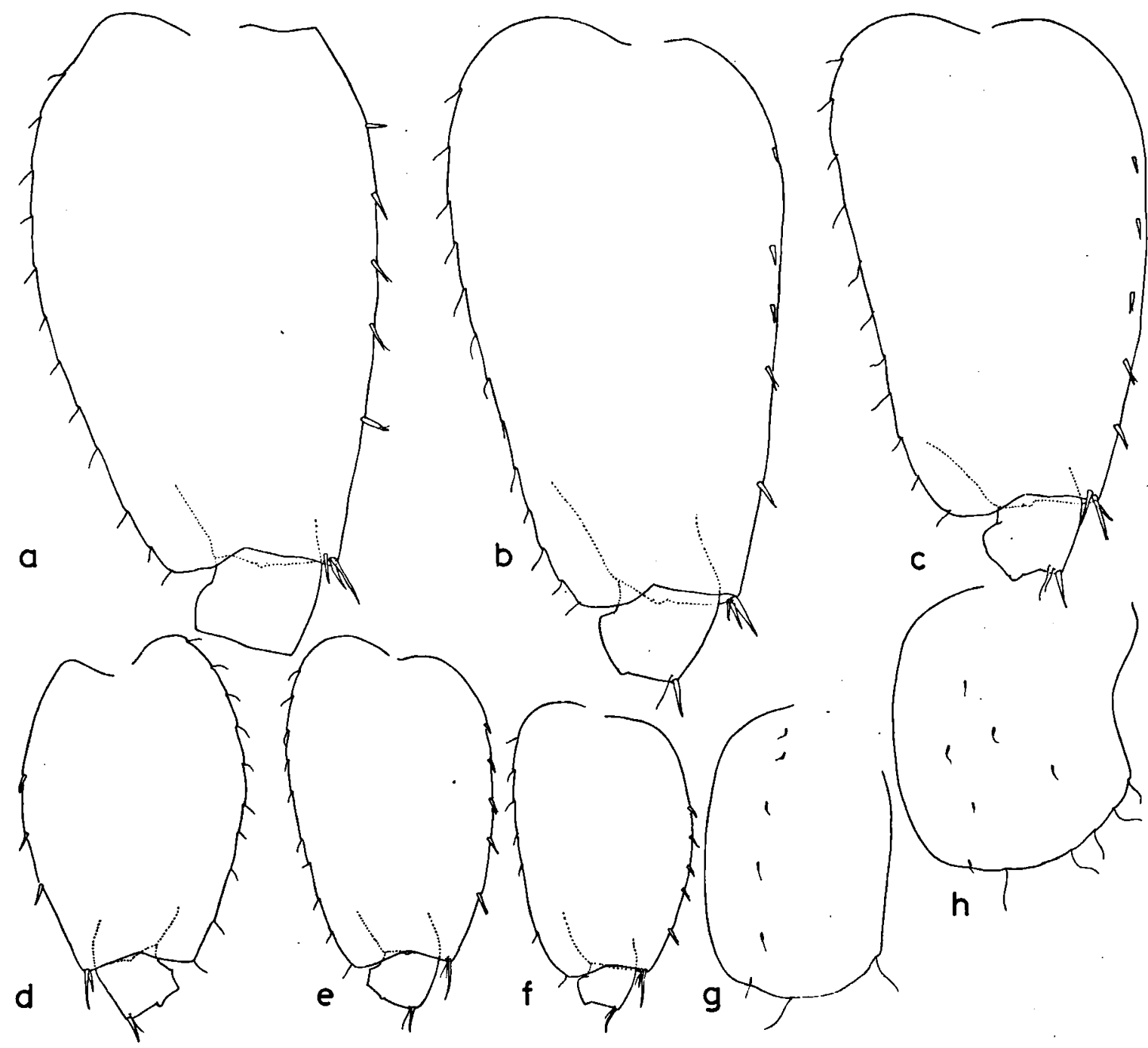

Fig. 10. Pseudoniphargus elongatus Stock, 1980 (a-c, o $7.5 \mathrm{~mm}$ from Cueva de Coventosa; d-f, $\$ 5.4 \mathrm{~mm}$ from Cueva del Orillón; g, h, ơ $6.5 \mathrm{~mm}$ from shallow cave near Miera): a, basis pereiopod 7 ơ (scale M); b, basis pereiopod 6 $\sigma^{\circ}(\mathrm{M})$; c, basis pereiopod $5 \sigma^{\circ}(\mathrm{M})$; d, basis pereiopod 7 ( $(\mathrm{M})$; e, basis pereiopod 6 \% (M); f, basis pereiopod 5 \& $(\mathrm{M}) ; \mathrm{g}$, coxal plate pereiopod $3 \sigma^{\circ}(\mathrm{M}) ; \mathrm{h}$, coxal plate pereiopod $4 \sigma^{\circ}(\mathrm{M})$. 
Telson: about as long as wide, with 2-4 subapical spines; narrow, V-shaped distal notch.

Female: Gnathopods slightly more elongated. Posterodistal angle of basis of P6 and P7 (figs. $10 \mathrm{~d}, \mathrm{e})$ less overhanging. Other characters as in males, except uropod 3 (figs. 9b, d).

Remarks. - Specimens from the Cubera resurgence are all small-sized, nevertheless an ovigerous female $(3.4 \mathrm{~mm})$ and males $(2.6 \mathrm{~mm})$ with a markedly elongated uropod 3 were present. Specimens from the interstitial of the Río Yera and Río Cerneja are differing from the populations related to karst biotopes in having more spines on the peduncle of $U 1$ and the rami of $\mathrm{U} 1$ and $\mathrm{U} 2$.

This is the only species in northern Spain with strongly elongated pedunculus and exopodite, and a distinctly sexually differentiated uropod 3. This character is also found in africanus, adriaticus, and some species from southern Spain.

\section{Pseudoniphargus burgensis $n$. sp.}

(Figs. 11-12)

Material examined. - Prov. Burgos, Merindad de Sotoscueva, Hornillayuso, Cueva la Torcona (top resurgence of the Ojo Guareña cave system), UTM coordinates VN504625, alt. $700 \mathrm{~m}$; 15 July 1984 (sta. 84$7 / 13$ ), in galleries with stagnant or slowly running water, the substrate consists of rock, fine sand and little organic debris; $1 \sigma^{\circ}$ holotype, $1 \&$ allotype (ovigerous), $90^{\circ} \sigma^{\prime \prime}$ and 2 ovigerous $\$ \$$ (paratypes) (ZMA coll. no. Amph. 108.023).

Description. - Largest male $4.4 \mathrm{~mm}$, ovigerous females $3.9-4.9 \mathrm{~mm}$ (carrying 2-3 eggs).

Male: Antenna $135-45 \%$ of body length; peduncle little longer than that of A2; flagellum of about 12 segments. Antenna 2 (fig. 11d): peduncle segment 4 armed with setae and two distal spines, segment 5 with long setae (distal setae exceeding length of first flagellum segment); flagellum of about 7 segments.

Mandible palp (fig. $11 \mathrm{~m}$ ) slender, segment 1 somewhat elongated, segment 2 with few ventral setae, segment 3 with 1 A-seta, 1 B-seta, 7 slender D-setae and 3 or 4 E-setae. Maxilla 1 (fig. 11j): inner lobe with 6 spines, in the largest male 5 spines are multidenticulate, while in other specimens studied ( $Q 4.1$ and $\sigma 3.5 \mathrm{~mm}$ ) 3 spines are multidenticulate and the others unidenticulate; palp slender, distally with 5 elements. Maxilla 2 and upper lip without peculiarities. Maxillipedal (fig. 12g) inner lobe very slender, distally with spines and setae; outer lobe laterally with only few spines, palp without peculiarities.

Gnathopod 1 (fig. 11b): coxal plate with 3 distal setae; carpus somewhat longer than propodus, posterior margin with 4 setal rows; posterior margin of propodus with 2 setal groups, palmar angle (fig. 11c) with 5 spines. Gnathopod 2 (fig. 11a): coxal plate rather narrow, with 2 distal setae; carpus strongly elongated, almost of equal length as propodus, posteriorly with 4-5 rows of setae; propodus slender, posterior margin with 3 setal groups; 3 palmar angle spines (fig. 11e) (a smaller male has only 2 of these spines and in the largest male one of these spines is more proximally implanted); unguis slightly shorter than dactylus.

Dactylus and unguis of P3-P4 (fig. 12c) very slender. Coxal plate of P3 (fig. 12c) narrow, convex distal margin with 2-3 setae. Plate 4 (fig. 12b) slender, with shallow posterior excavation and 4-5 distal setae.

Pereiopods 5 to 7: basis (figs. 12a, d, e) expanded with wide and overhanging posterior lobe; distal propodal spines long; dactylus and unguis (figs. 12a, $f$ ) very slender. Basis of P5 (fig. 12e) anteriorly with 4 little spines and posteriorly with 7-9 setules. P6 (fig. 12a): basis somewhat longer than that of $\mathrm{P} 5$, anteriorly with 4 elements and posteriorly with $8-9$ setules. Basis of P7 (fig. 12d) equal to P6, with anteriorly 5 spines and posteriorly 7-8 setules.

Epimera without spines on lower margin, posterior corner pointed, posterior margin almost unarmed.

Uropod 1 (fig. 11-1): armed with slender spines; peduncle with curved basoventral spine, no medial spines, and 1 or 2 dorsal spines; rami slender, endopodite with marginal and terminal spines, margins of exopodite unarmed. Uropod 


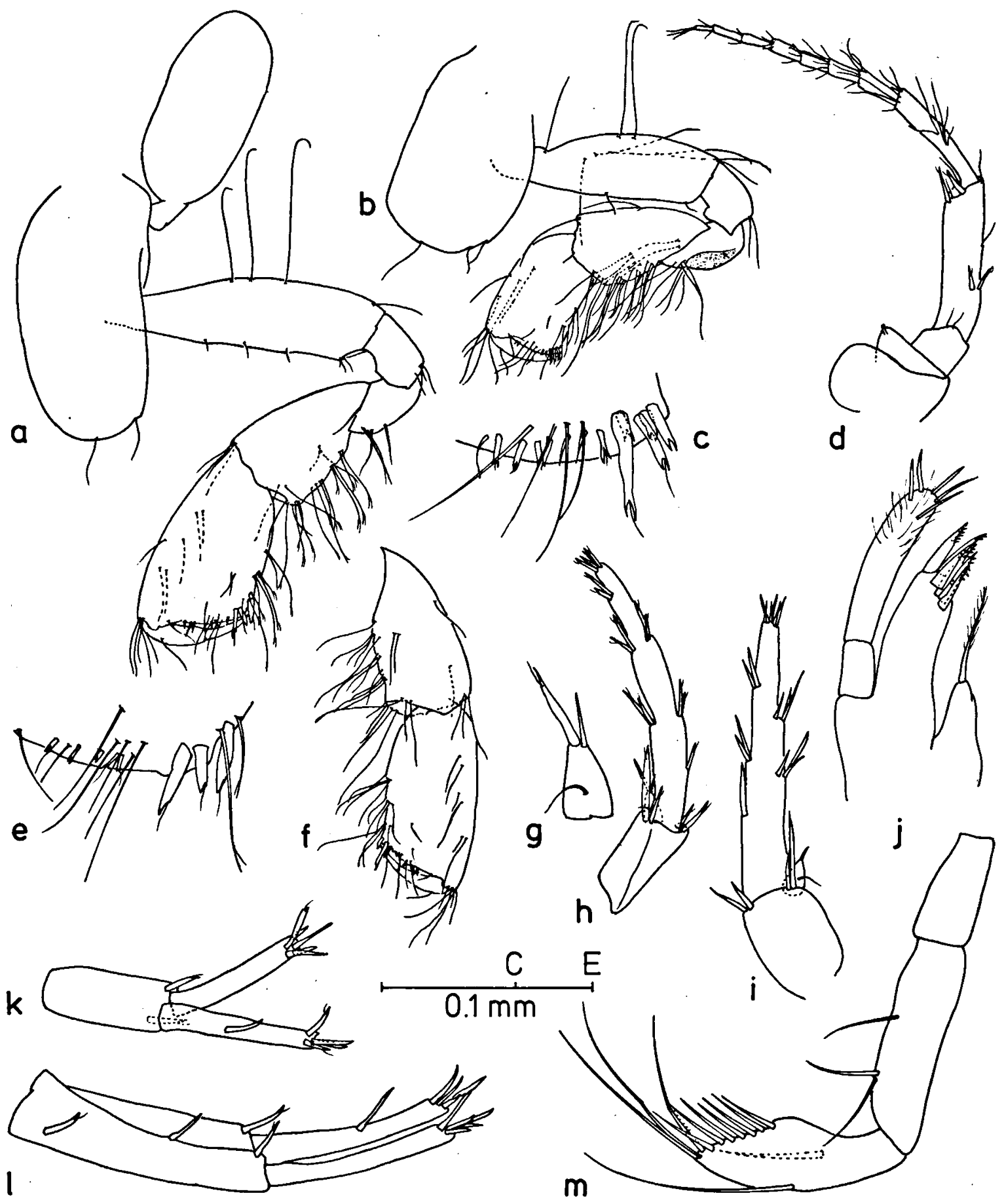

Fig. 11. Pseudoniphargus burgensis $\mathrm{n}$. sp. ( $\left({ }^{\circ}\right.$ paratype $4.4 \mathrm{~mm}$, and $\$$ allotype $4.1 \mathrm{~mm}$, both from Cueva la Torcona): a, gnathopod $20^{\circ}$ (scale A); b, gnathopod $10^{\circ}$ (A); c, palmar angle gnathopod $10^{\circ}(\mathrm{E})$; d, antenna $2 \sigma^{\circ}$ (A); e, palmar angle gnathopod $2 \sigma(\mathrm{C})$; f, gnathopod 2 \% (A); g, endopodite uropod $3 \sigma^{\circ}(\mathrm{C})$; h, uropod $3 \sigma^{\circ}(\mathrm{A})$; $\mathrm{i}$, uropod 3 \% (A); j, maxilla $10^{\circ}(\mathrm{C})$; $\mathbf{k}$, uropod $2 \sigma^{\circ}(\mathrm{A})$; 1 , uropod $10^{\circ}(\mathrm{A})$; $\mathrm{m}$, mandible palp o $(\mathrm{C})$. 


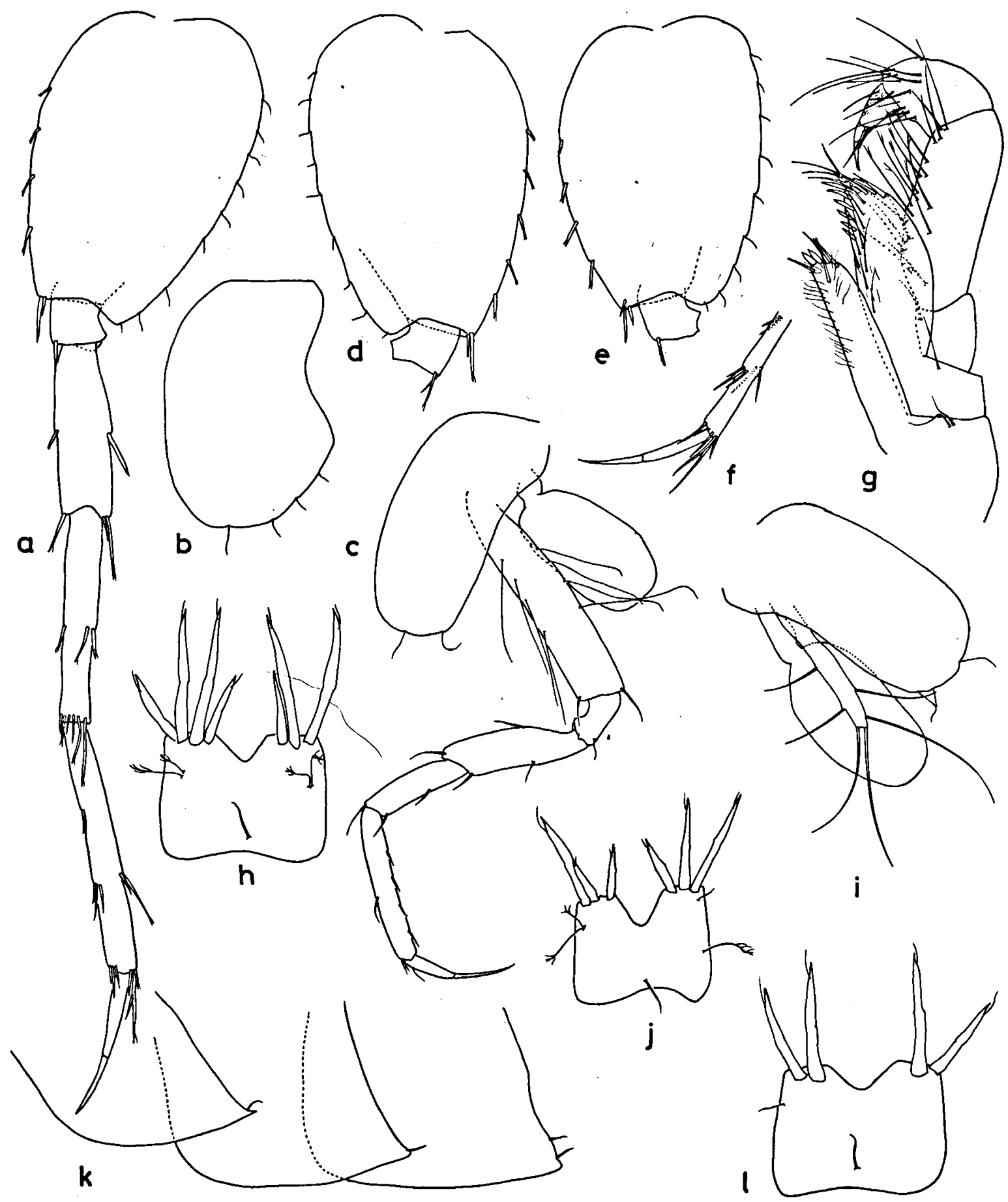

Fig. 12. Pseudoniphargus burgensis n. sp. (a-g, l, $\sigma^{\circ}$ paratype $4.4 \mathrm{~mm}, \mathrm{j}, \sigma^{\circ}$ paratype $3.7 \mathrm{~mm}$, and h, i, $\mathrm{k}, \uparrow$ allotype 4.1 $\mathrm{mm}$, from Cueva la Torcona): a, pereiopod $6 \sigma^{\circ}$ (scale F); b, coxal plate pereiopod $4 \sigma^{\circ}(\mathrm{F})$; c, pereiopod $3 \sigma^{\circ}(\mathrm{F})$; $d$, basis pereiopod $70^{\circ}(\mathrm{F})$; e, basis pereiopod $5 \sigma^{\circ}(\mathrm{F})$; f, claw pereiopod $5 \sigma^{\circ}(\mathrm{F})$; g, maxilliped $\sigma^{\circ}(\mathrm{H})$; h, telson $\$(\mathrm{H})$; i, coxal plate, gill, and oostegite pereiopod 3 ९ $(F) ; j$, telson $\sigma^{\circ}(\mathrm{H}) ; \mathrm{k}$, epimera $९(\mathrm{~F}) ; 1$, telson $\sigma^{\circ}(\mathrm{H})$. 
2 (fig. 11k): distal peduncle spines slender; rami slender, endopodite with 1 medial spine (marginal endopodite spines in U1 and U2 are lacking in smaller specimens). Uropod 3 (fig. $11 \mathrm{~h})$ : peduncle about 1.5 times as long as wide; endopodite (fig. $11 \mathrm{~g}$ ) with basal seta and 1 (or 2 in $\sigma^{\circ} 4.4 \mathrm{~mm}$ ) apical spines. Exopodite, in two males of 2.6 and $4.4 \mathrm{~mm}$ length, 7.2 and 8.5 times as long as wide, respectively; margins with 2 or 3 groups of spines, each group consisting of 2-3 spines, terminal spines shorter than marginal spines.

Telson (figs. 12j, l) wider than long; rather deep, V-shaped emargination; each side with 24 terminal spines (which can exceed the length of the telson).

Female: Gnathopod 1 with wider coxa, both gnathopods with more elongated carpus, gnathopod 2 (fig. 11f) with slender propodus. Oostegites (fig. 12i) with 5-6 setae. Basis of P6 little more globular. Exopodite of U3 (fig. 11i) in the only measured female $(4.1 \mathrm{~mm}) 6.5$ times as long as wide. Other characteristics similar to those of males, figured are telson (fig. 12h), coxa 3 (fig. 12i), and epimera (fig. 12k).

Remarks. - This species is characterized by the outer lobe of maxilla 1 carrying 6 spines, few D-setae on the mandible palp, slender maxillipedal inner lobe, elongated carpus of $\mathrm{P} 1$ and $\mathrm{P} 2$, slender propodus of $\mathrm{P} 2$, very slender claws of P3-P7, absence of medial peduncle and marginal exopodite spines on $\mathrm{U} 1$, and the deep, $\mathrm{V}$-shaped distal notch of the telson. As in the other species from Burgos and Basque Country, the peduncle and exopodite of U3 are short and not sexually dimorphic. Ps. burgensis shows most affinities with eborarius and jereanus. It resembles the former in the propodus of $\mathrm{P} 2$, slender claws of P3-P7, morphology of the basis of P5-P7, armature of U1, and telson. It resembles jereanus in the mandible palp, slender claws of P3-P7, shape of the basis of P5-P7, armature of $\mathrm{U} 1$, and telson.

Etymology. - The specific name burgensis is a toponym alluding to the province of Burgos. The type-locality, Cueva la Torcona, is part of the Ojo Guareña cave system, the most extended cave of this province (and of Spain as well).

\section{Pseudoniphargus eborarius n. sp.}

(Figs. 13-14)

Material examined. - Prov. Burgos, Merindad de Valdevielso, Valdenoceda, SBR Fuente del Marfil (resurgence on the west-bank of the Río Ebro), UTM coordinates VN516460, alt. $700 \mathrm{~m} ; 6$ Apr. 1984 (sta. 844/2), 1 ovigerous $\&$ holotype, $1 \sigma^{\circ}$ allotype, $1 \sigma^{\circ}, 3$ \% (one ovigerous) and 4 juvs. (paratypes) (ZMA coll. no. Amph. 108.022).

Description. - Length of males 3.6 and 3.8 $\mathrm{mm}$; ovigerous females 3.4 and $4.8 \mathrm{~mm}$ (carrying 1 and 2 eggs, respectively).

Female: Antenna 1 about half of body length; peduncle shorter than peduncle of A2; flagellum of about 12 segments. Antenna 2 like burgensis. Mandible palp: segment 1 somewhat elongated; segment 2 with few distoventral setae; segment 3 with 2 A-setae, 3 B-setae, 11 D-setae, and 3 E-setae. Maxilla 1: outer lobe with 7 spines, inner spine multidenticulate, others unidenticulate; palp less slender than in burgensis and distally armed with 6 elements. Other mouthparts without peculiarities.

Gnathopod 1 (fig. 13a): coxal plate with 4-5 setae on convex distal margin; carpus of about same length as propodus, posterior margin with 4-5 setal rows; propodal posterior margin with 2-3 groups of setae; palmar margin with relatively numerous long setae, angle with 4 spines. Gnathopod 2: lower margin of coxal plate with 4-5 setae; carpus not elongated, posterior margin with 4-5 rows of setae; propodus rather strong, posterior margin with 4 groups of setae; unguis almost as long as dactylus.

Claws of P3-P7 (fig. 13e) slender, but less slender than in burgensis. Coxal plates of P3 and P4 (figs. 13b, i) wider than in burgensis, with 3-6 and 4-5 distal setae, respectively. Oostegites (fig. 13b) with 8-9 setae.

Pereiopod 5: basis (fig. 14c) with rather straight margins, bearing anteriorly 8 elements and posteriorly 13 setules, posterior lobe wide and overhanging; distal propodal spines long. Pereiopod 6: basis (fig. 14b) longer than that of 


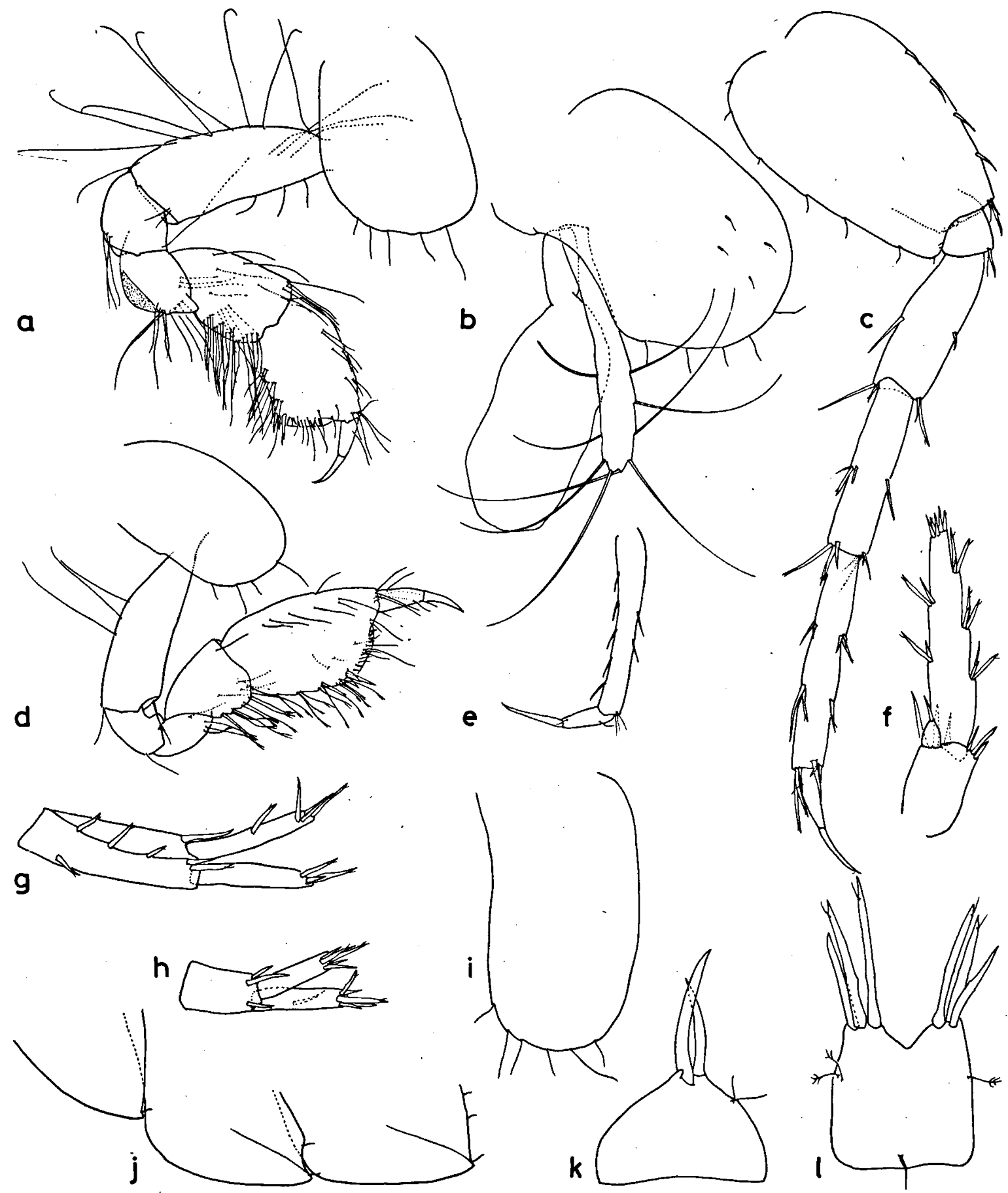

Fig. 13. Pseudoniphargus eborarius n. sp. ( $\%$ holotype $4.8 \mathrm{~mm} ; \sigma$ allotype $3.6 \mathrm{~mm}$, from Fuente del Marfil): a, gnathopod 1 (scale F); b, coxal plate, gill, and oostegite pereiopod 4 \& (F); c, pereiopod $6 \sigma^{\circ}$ (F); d, gnathopod $20^{\circ}(\mathrm{F})$; e, claw pereiopod 4 \& (F); f, uropod 3 \& (F); g, uropod $1 \sigma^{\circ}(\mathrm{F}) ; \mathrm{h}$, uropod $2 \sigma^{\circ}(\mathrm{F})$; i, coxal plate pereiopod 3 \% (F); j, epimera १(N); k, anomalous telson $\$(\mathrm{H}) ; 1$, telson $\sigma^{\circ}(\mathrm{H})$. 


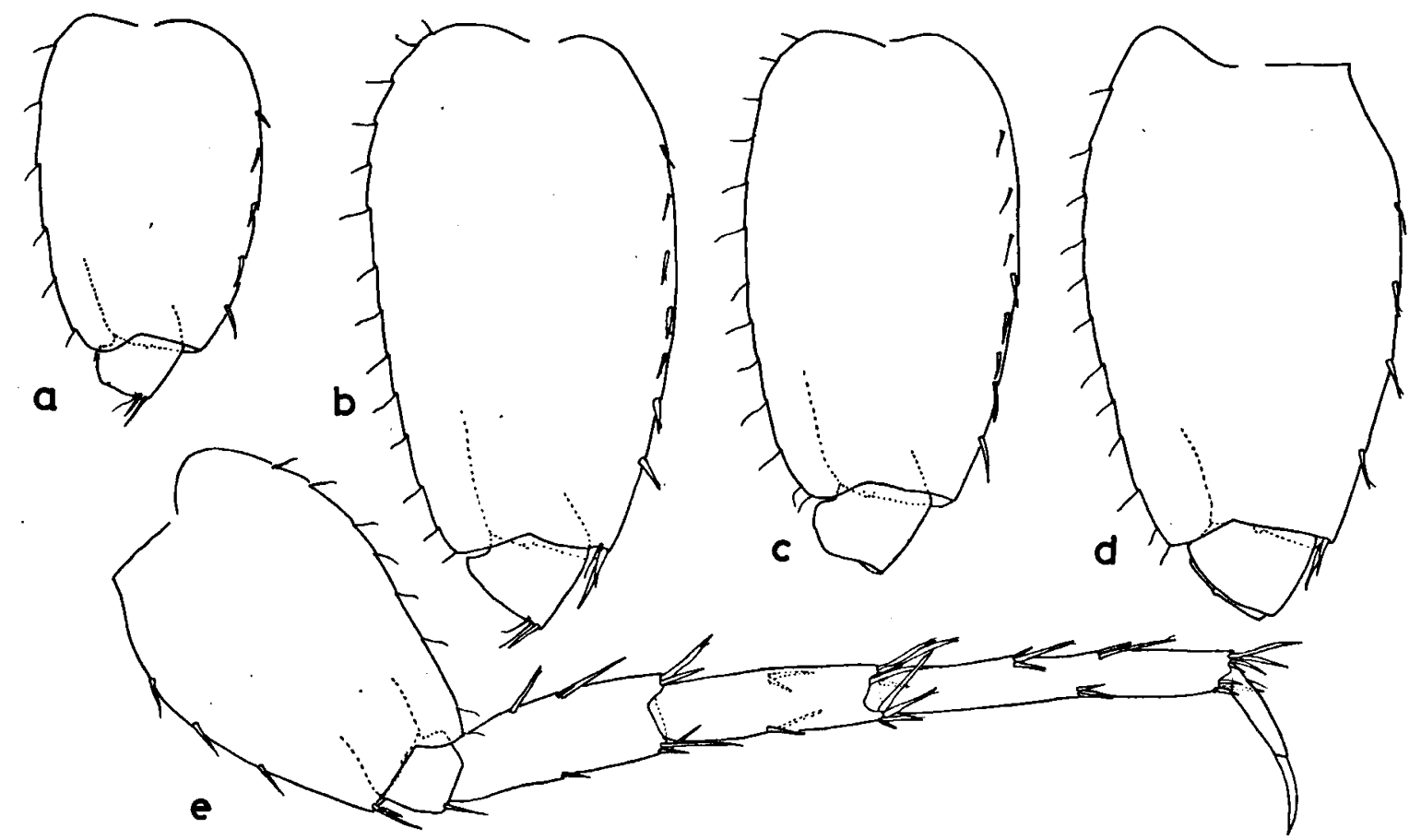

Fig. 14. Pseudoniphargus eborarius n. sp. ( $Q$ holotype $4.8 \mathrm{~mm} ; \sigma^{\circ}$ allotype $3.6 \mathrm{~mm}$, from Fuente del Marfil): a, basis pereiopod $5 \circ$ (scale F); b, basis pereiopod 6 \% (F); c, basis pereiopod 5 \% (F); d, basis pereiopod 7 \% (F); e, pereiopod $7 \circ(\mathrm{F})$.

P5 or P7, margins rather straight, anteriorly with 7 elements and posteriorly with 14 setules, posterior lobe wide, and slightly overhanging. Pereiopod 7: basis (fig. 14d) tapering, anterior margin with 4 elements, posterior margin with 12 setules, posterior lobe wide, and overhanging.

Epimera (fig. 13j) without spines on lower margin, posterodistal corner of plate 1 acute, plates 2 and 3 with rectangular corners; posterior margins with few short setae.

Uropod 1: peduncle with basoventral spine, no medial spines, 3 dorsal spines, distal spines not very slender; rami equal sized, not markedly slender, endopodite with 1 marginal spine, exopodite with 0-1 marginal spine, terminal spines rather slender. Uropod 2: peduncle without dorsal spine; rami with 0-2 marginal spines. Uropod 3 (fig. 13f): peduncle about 1.5 times as long as wide; exopodite rather wide, 45 times as long as wide, margins with 2 or 3 setal groups, each group with up to 3 spines, terminal spines shorter than lateral spines.

Telson longer than wide, somewhat tapering, narrow, with $\mathrm{V}$-shaped distal notch and 3 terminal spines on each side; $4.8 \mathrm{~mm}$ long female with anomalous telson, triangular without distal emargination and one group of 2 terminal setae (fig. 13k).

Male: All available specimens small, therefore difficult to discuss secondary sexual differences. Peduncle of antennae of equal length. Mandible palp of $3.6 \mathrm{~mm}$ large male with $1 \mathrm{~A}$-seta, 1 B-seta, 7 D-setae, and 3 E-setae. Uropod 3 as in female. Figured are gnathopod 2 (fig. 13d), pereiopods 5 to 7 (figs. 13c and 14a, e), uropods 1 and 2 (figs. $13 \mathrm{~g}, \mathrm{~h}$ ), and telson (fig. 13-l).

Remarks. - This species is close to burgensis, see remarks under the latter, but it has no modified mouthparts and less elongated gnathopods. It principally differs from jereanus 
in less strongly expressed sexual differences in the gnathopods.

Etymology. - The specific name eborarius (from the Latin, meaning "artisan of ivory") is proposed because the animal is described from the Fuente del Marfil which means Spring of Ivory.

Pseudoniphargus jereanus n. sp. (Figs. 15-16)

Material examined. - Prov. Burgos, Junta de Oteo, Quincoces de Yuso, Cueva de Agua (resurgence cave, rising of the Río Jerea), UTM coordinates VN807620, alt. $700 \mathrm{~m}$; 9 Apr. 1984 (sta. 84-4/16), in lake with slowly running water between boulders in twilight zone of the cave, $1 \%$ holotype, 1 ovigerous $Q$ and $1 \sigma^{\circ}$ (paratypes) (ZMA coll. no. Amph. 108.017).

Prov. Burgos, Berberana, Murita, Cueva de Murita 1, UTM coordinates VN951532, alt. 620 m; 9 Apr. 1984 (sta. 84-4/18), descending gallery giving access to water table, during floods the water flows through the entrance, $10,1 \%$, both semi-adult and 2 juvs. (probably this species) were captured between boulders in the lake.

Description. - Length of female holotype $4.5 \mathrm{~mm}$, ovigerous female paratype and male paratype 4.2 and $4.5 \mathrm{~mm}$, respectively.

Female: Antenna 1: about half as long as body; peduncle and flagellum as in burgensis. Antenna 2 resembling that of burgensis.

Mandible palp (fig. 16a) segment 2 with few setae, segment 3 with 1-2 A-setae, 1-2 B-setae, 7 slender D-setae and $3 \mathrm{E}$-setae. Outer lobe of maxilla 1 variable with up to 4 multidenticulate spines. Other mouthparts without peculiarities.

Both gnathopods small. Gnathopod 1 (fig. 15a): lower margin of coxal plate with 5 setae; carpus and propodus of about same length, posterior margin of carpus with 3 rows of setae, posterior margin of propodus with 2 groups of setae, 4 palmar angle spines. Gnathopod 2 (fig. 15d): lower margin of coxal plate with 4 setae; carpus little elongated; propodus very slender, bearing 4 groups of setae on posterior margin, 3 palmar angle spines; unguis slightly shorter than dactylus.

Dactylus and unguis of P3-P7 (figs. 15b, c, k) very slender (like burgensis). Lower margins of coxal plates 3 and 4 (figs. 15k, 1) with 4 and 5 setae, respectively. Oostegites as in burgensis.
Pereiopods 5 to 7 (figs. 15b, c, h) with wide posterior basal lobes, strongly overhanging. Pereiopod 5 (fig. 15b): anterior margin of basis convex, with 4-5 spines, posterior margin rather straight with 9 setules; distal propodal spines very long. Pereiopod 6 (fig. 15c): basis somewhat larger than that of P5 or P7, shape rather similar to P5. Pereiopod 7: basis (fig. $15 \mathrm{~h})$ with convex margins, anteriorly with $3-4$ spines, posteriorly with 7 setules.

Epimeral plates with unarmed lower and posterior margin, posterior corner rectangular.

Uropod 1 (fig. 16d): peduncle with basoventral spine, medial spines lacking, 2-3 dorsal spines; endopodite sometimes with a lateral spine. Uropod 2 (fig. 16b) with rather slender rami. Uropod 3 (fig. 16e): peduncle not elongated; exopodite tapering, length/width ratio 4.9. Margins of exopodite with 2-3 groups of spines, each group with up to 2 spines, terminal spines shorter than lateral spines.

Telson (fig. 16c) hardly longer than wide, with rather wide and shallow V-shaped distal notch; each side with 2 terminal spines.

Male: Only specimen from the type-locality with very short claws on P5 to P7 (fig. 15i), short terminal spines on rami of $\mathrm{U} 1$ and $\mathrm{U} 2$, and regenerated left $\mathrm{U} 3$, possibly as a result of disturbances in the development of the animal. Sexual differences therefore hard to interpret precisely.

Coxa of P1 with 2 distal setae; carpus of P2 not elongated. Propodus of P2 (fig. 15e) strong with 3 posterior setal groups. Coxa of P3 (fig. 15f) wide with 1 distal seta (probably anomalous). Basis of P7 illustrated (fig. 15g). Exopodite of U3 6.2 times as long as wide. Epimeral plates (fig. 15j) as illustrated.

Remarks. - This species is closely related to the other two species from N.E. Burgos, burgensis and eborarius, and with gorbeanus from Basque Country, see remarks under these species for their morphological differences.

Etymology. - The proposed name jereanus is a toponym referring to the Río Jerea which arises at the type-locality. 


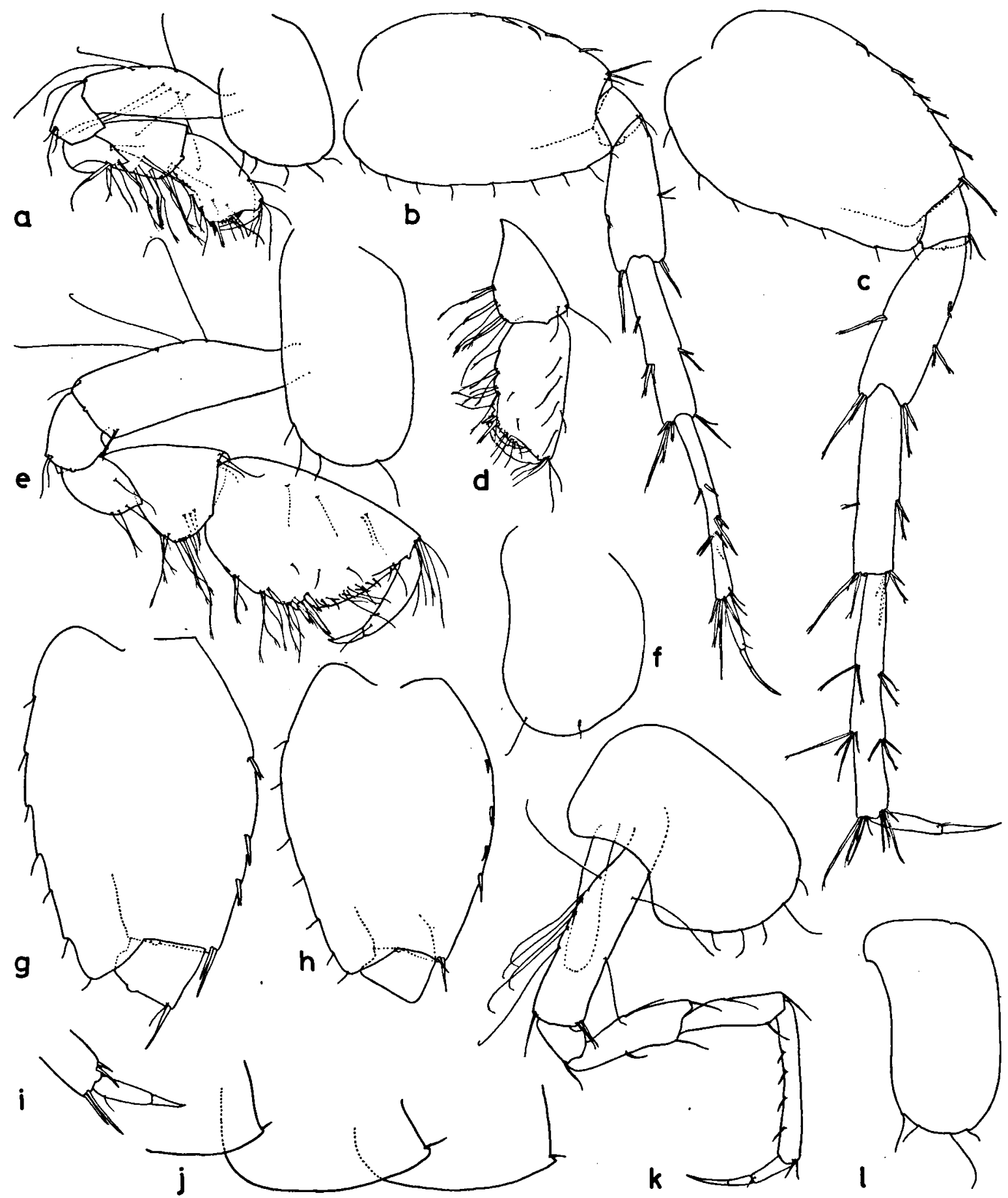

Fig. 15. Pseudoniphargus jereanus n. sp. ( $Q$ holotype $4.5 \mathrm{~mm}$; O paratype $4.5 \mathrm{~mm}$, from Cueva de Agua): a, gnathopod 1 \% (scale F); b, pereiopod 5 \& (F); c, pereiopod 6 \% (F); d, distal part gnathopod 2 \% (F); e, gnathopod 2 o (F); f, coxal plate pereiopod $30^{\circ}(\mathrm{F}) ; \mathrm{g}$, basis pereiopod $70^{\circ}(\mathrm{F}) ; \mathrm{h}$, basis pereiopod 7 \% (F); i, claw pereiopod 7 o $^{\circ}(\mathrm{F})$; $\mathrm{j}$, epimera $\sigma(\mathrm{K})$; $\mathrm{k}$, pereiopod $4 \%(\mathrm{~F})$; 1 , coxal plate pereiopod $3 \&(\mathrm{~F})$. 

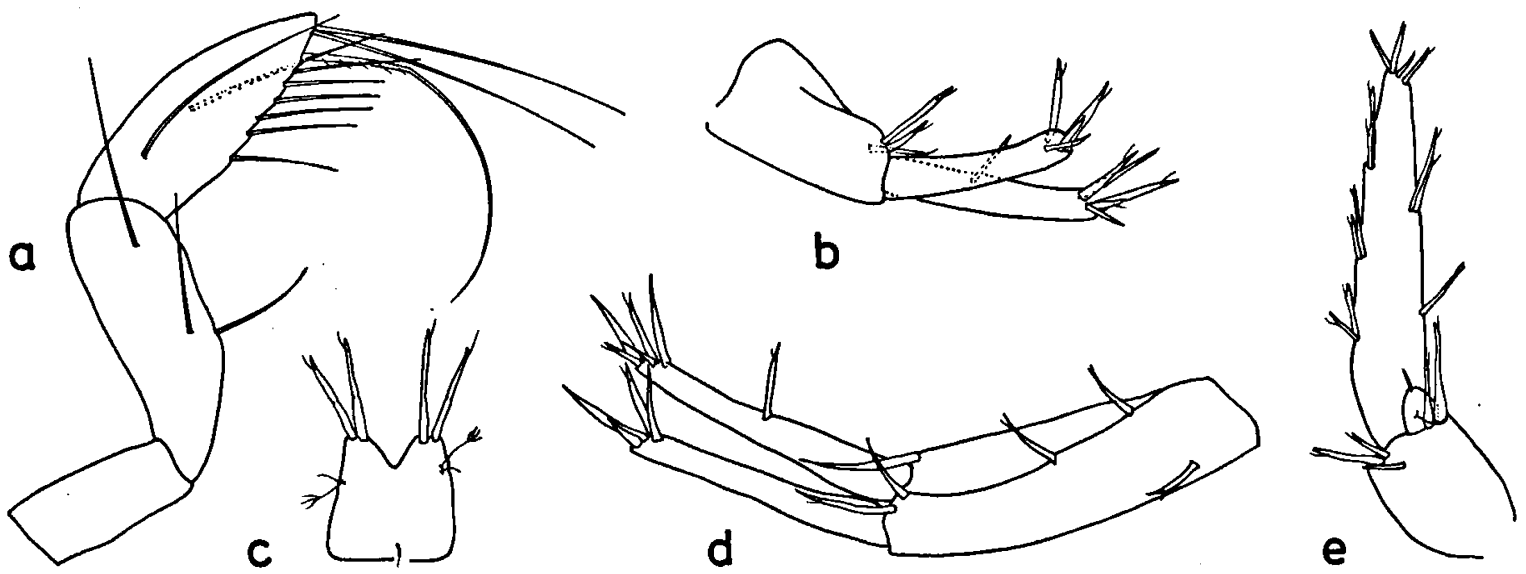

Fig. 16. Pseudoniphargus jereanus n. sp. ( $Q$ holotype $4.5 \mathrm{~mm}$, from Cueva de Agua): a, mandible palp (scale C); b, uropod 2 (A); c, telson (A); d, uropod 1 (A); e, uropod 3 (A).

\section{Pseudoniphargus sp. 1}

Material examined. - Prov. Burgos, Valle de Sedano, Moradillo de Sedano, Cueva de la Salmarina, UTM coordinates VN428283, alt. $850 \mathrm{~m} ; 31$ Mar. 1984 (sta. 84-3/39), in brooklet with erosion basins not far from the entrance, one small damaged $\sigma$.

Remarks. - The only small available specimen is lacking pereiopods 7 and uropods 3. Antennae, pereiopods 3 and 4, epimera, uropods 1 and 2, and telson resemble those of jereanus and eborarius.

The mandible has a slender palp (like burgensis), segment 2 with only few setae, segment 3 with 1 A-seta, 2 B-setae, 3 D-setae (abnormality?), and 3 E-setae. Outer lobe of maxilla 1 with 7 spines, one of which multidenticulate, other spines unidenticulate, palp slender. Maxillipedal inner lobe slender (like burgensis).

Carpus of gnathopod 1 somewhat shorter than propodus. Gnathopod 2: carpus not elongated, propodus rather strong.

Pereiopods 5 and 6 are different from those of other species in the area, basis rectangular, with wide and slightly overhanging posterior lobe.

Because only one damaged male has been found at this locality, it is impossible to ascertain its taxonomic status.
Pseudoniphargus gorbeanus n. sp. (Figs. 17-18)

Material examined. - Prov. Alava, Cigoitia, Manantial de Gorbea (resurgence cave) near the Embalses de Gorbea at the south-side of the Sierra de Gorbea, UTM coordinates WN210615, alt. 700 m; 12 Apr. 1984 (sta. 84-4/25), in slowly running subterranean river with gravel and loam, $1 \sigma$ holotype, 1 ovigerous $\&$ allotype, and about 250 paratypes (ZMA coll. no. Amph. 108.018).

Prov. Alava, Cigoitia, Artzegi'ko Goba 1, small cave at the south-slope of the Sierra de Gorbea, close to the wellknown cave Mairuelegorreta 1, UTM coordinates WN201634, alt. $820 \mathrm{~m}$; 16 Nov. 1983 (sta. 83-11/32), in a small dammed-up pool fed by a brooklet, 170 specimens.

Prov. Alava, Cigoitia, Cueva de Mairuelegorreta 1, UTM coordinates WN199635, alt. $880 \mathrm{~m} ; 12$ Apr. 1984 (sta. 84-4/26); in plastic barrels fed by drip water in the Galería de la Estación, $2 \sigma^{\circ} \sigma^{\circ}$ and $1 \%$; in the river at the Sala de la Cascada, $21 \sigma^{\circ}, 13 \% \propto$ (3 ovigerous) and 13 juvs.; in a little rimstone pool fed by drip water at the Galería de los Caracoles, $20^{\circ} 0^{\circ}$ and $3 \% \%$; in a large pool with mud bottom at the entrance of the Sala de Peña Grande, 2 ơ , 3 \& ( 1 ovigerous) and 2 juvs.

Description. - Largest males and females, 5.5 and $5.8 \mathrm{~mm}$, respectively; ovigerous females ranging from 5.0 to $5.8 \mathrm{~mm}$ (carrying 2-3 eggs).

Male: Antenna 1 (fig. 18e) $50-70 \%$ of body length; peduncle longer than that of $\mathrm{A} 2$; accessory flagellum hardly exceeding length of 
first flagellum segment; flagellum of 14-18 segments, length of aesthetascs $1 / 2-3 / 4$ of corresponding segment. Antenna 2 (fig. 18a): peduncle segment 4 armed with short setae and two distal spines, segment 5 densely armed with long setae; flagellum of 8-10 segments, proximal segments with long setae.

Mandible palp (fig. 18c) slender, segment 2 with few setae, segment 3 with 1-2 A-setae, 1 Bseta, 10-12 D-setae and 3 E-setae. Maxilla 1: outer lobe with 1 or 2 multidenticulate inner spines. Other mouthparts without peculiarities.
Gnathopod 1: distal coxal margin (fig. 17c) with 6 setae; carpus little shorter than propodus, posterior margin with 4 rows of setae; propodal posterior margin with 3 setal groups, palmar angle with 4-6 bifid spines. Gnathopod 2 (figs. $17 \mathrm{~g}, 1$ ): lower margin of coxa convex with 5-7 setae; posterior margin of carpus with 3 setal groups; propodus strong, posterior margin with 4 setal groups, palmar angle (fig. 17d) in the larger males with 4 spines, in the smaller males with 3 spines; unguis $3 / 4$ of length of dactylus.
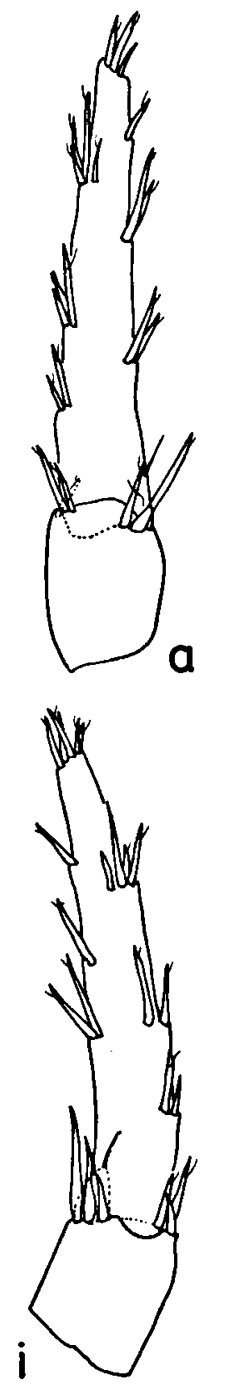
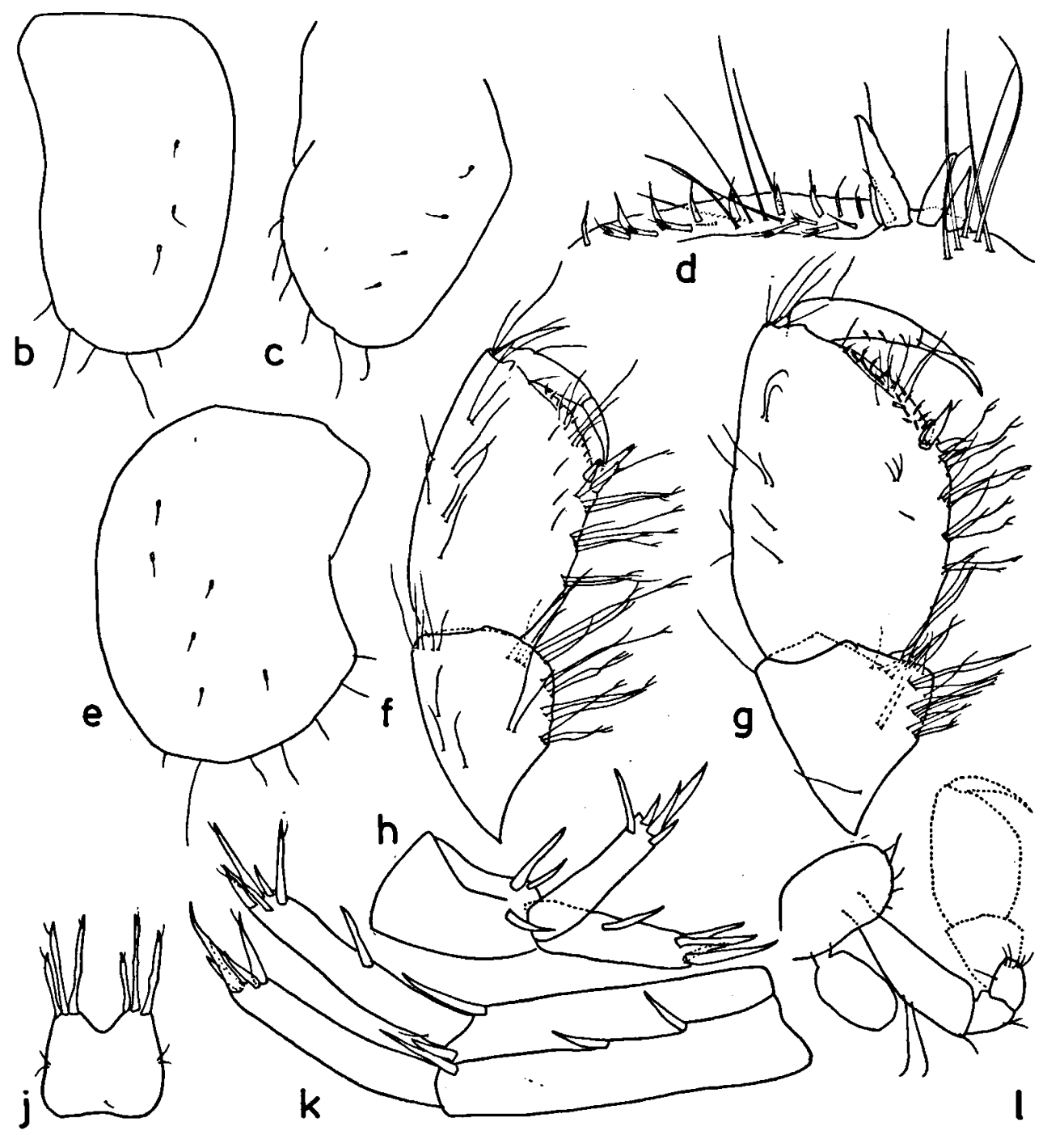

Fig. 17. Pseudoniphargus gorbeanus n. sp. ( $\sigma^{\circ}$ paratype $5.0 \mathrm{~mm}$; o ovigerous paratype $5.0 \mathrm{~mm}$, from Manantial de Gorbea): a, uropod 3 \& (scale A); b, coxal plate pereiopod $30^{\circ}$ (A); c, coxal plate pereiopod $10^{\circ}$ (A); d, palmar margin gnathopod $2 \circ(\mathrm{C})$; e, coxal plate pereiopod $4 \sigma^{\circ}$ (A); f, distal part gnathopod 2 \& (A); g, distal part gnathopod $2 \sigma^{\circ}$ (A); h, uropod $2 \sigma^{\circ}$ (A); i, uropod $3 \sigma^{\circ}$ (A); j, telson $\sigma^{\circ}$ (A); k, uropod $10^{\circ}$ (A); 1 , gnathopod $20^{\circ}$ (D). 


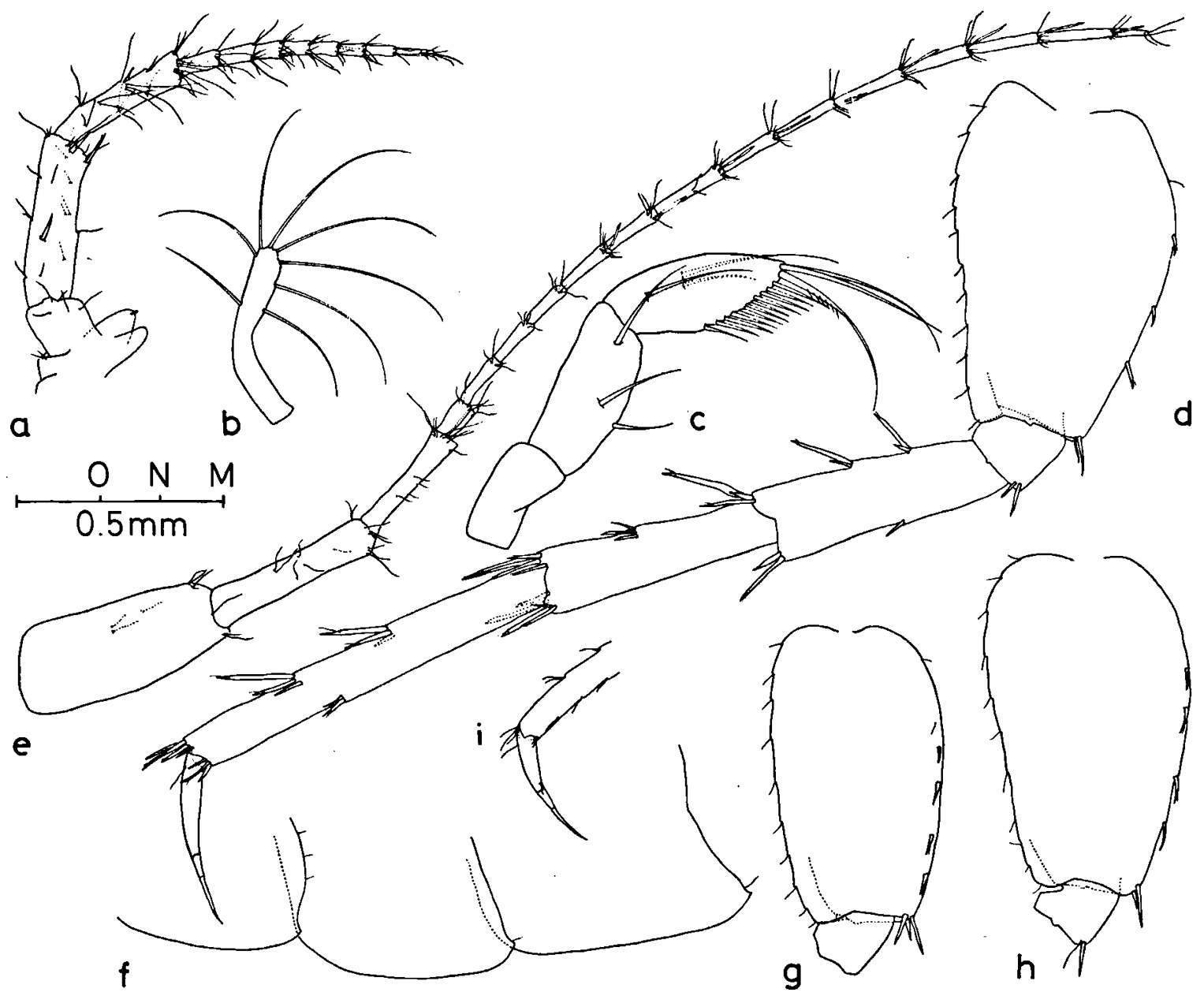

Fig. 18. Pseudoniphargus gorbeanus n. sp. ( $\sigma$ paratype $5.0 \mathrm{~mm} ; Q$ ovigerous paratype $5.0 \mathrm{~mm}$, from Manantial de Gorbea): a, antenna $2 \sigma^{\circ}$ (scale $\left.\mathrm{M}\right)$; b, oostegite pereiopod 4 Q (M); c, mandible palp $\sigma^{\circ}(\mathrm{P})$; d, pereiopod $7 \sigma^{\circ}(\mathrm{M})$; e, antenna $10^{\circ}(\mathrm{M})$; f, epimera $0^{\circ}(\mathrm{M})$; g, basis pereiopod $50^{\circ}(\mathrm{M}) ; \mathrm{h}$, basis pereiopod $60^{\circ}$ (M); i, claw pereiopod $4 \sigma^{\circ}(\mathrm{M})$.

Dactylus and unguis of P3-P7 very slender (figs. 18d, i). Lower margins of coxal plates 3 and 4 (figs. $17 \mathrm{~b}, \mathrm{e}$ ) with $5-7$ and $6-7$ setae, respectively.

Pereiopods 5 to 7 (figs. 18d, g, h): posterior lobes of basis weakly developed; posterodistal angles in smaller specimens more prominently overhanging than in larger specimens. Pereiopod 5 elongated, much longer than P4; basis (fig. 18g) rectangular, anterior margin with 4-6 elements, posteriorly with 10 setules, posterodistal angle slightly overhanging; distal propodal spines long. Pereiopod 6 elongated, about of same length as P7; basis (fig. 18h) rect- angular, anteriorly somewhat convex, with 4-5 elements, posteriorly straight, with $10-11$ setules; posterodistal angle overhanging. Pereiopod 7 (fig. 18d) basis tapering, anterior margin somewhat convex with 4-5 elements, posterior margin straight with 9-11 setules, posterodistal angle overhanging.

Epimera (fig. 18f) without spines on lower margin, posteroventral corner of plates 1 and 2 pointed, plate 3 with acute corner, posterior margin scarcely armed with setules.

Uropod 1 (fig. 17k): peduncle rather elongated, medial spines absent, 2-3 dorsal spines and basoventral spine present or absent; 
rami unequal (endopodite longer than exopodite), endopodite with 1-2 lateral spines, exopodite unarmed. Uropod 2 (fig. 17h) without peculiarities. Uropod 3 (fig. 17i): peduncle not elongated (about 1.3 times as long as wide); endopodite 5.4-7.0 times as long as wide, margins with 2-3 groups of spines, each group with up to 4 spines, terminal spines shorter than lateral spines.

Telson (fig. 17j) subquadrate, tapering, with $V$-shaped rather deep distal notch and 3 or 4 terminal spines on each side.

Female: Gnathopod 2 (fig. 17f) with more elongated carpus and slender propodus. Remaining characters, of which U3 illustrated (fig. 17a) as in male. Oostegite of P4 (fig. 18b) with 8 setae.

Remarks. - This species resembles jereanus in many characters (mandible palp, gnathopods, slender claws of P3-P7, uropods and telson). It mainly differs in antennal setation and shape of basis of P5-P7. It is also closely related to vasconiensis, see remarks under the latter.

Etymology. - The proposed specific name gorbeanus is a toponym referring to the Sierra de Gorbea, in which the localities of this species are situated.

Pseudoniphargus vasconiensis n. sp. (Figs. 19-20)

Material examined. - Prov. Navarra, Larraún, Allí, Cueva de Allí, UTM coordinates WN903602, alt. $630 \mathrm{~m}$; 18 June 1984 (sta. 84-6/33), in rimstone pools and dripwater pools, $1 \sigma$ holotype, 1 ovigerous $Q$ allotype and about 300 paratypes (16 ovigerous ९९) (ZMA coll. no. Amph. 108.019).

Prov. Guipuzcoa, Arechavaleta, Goronaeta, Manantial de Urbaltza (caught karst spring), UTM coordinates WN486632, alt. $440 \mathrm{~m} ; 15$ Nov. 1983 (sta. 83-11/31), $1 \%$.

Prov. Navarra, Larraún, Baraibar, Cueva Nacedero de Larraún, UTM coordinates WN884591, alt. $600 \mathrm{~m}$; in entrance lake of large resurgence cave, 27 Nov. 1983 (sta. 83-11/40), 1 damaged specimen and 17 June 1984 (sta. 84-6/32), 3 우오.

Prov. Guipuzcoa, Ataun, Aya, Manantial de Ur-Zuloa (resurgence), UTM coordinates WN713567, alt. $620 \mathrm{~m}$; 28 Nov. 1983 (sta. 83-11/43), between boulders and gravel near the entrance, $40^{\circ} 0^{\circ}$ and $3 \circ \%$.
Prov. Alava, Aspárrena, Ilárduya, Cueva de Porraipi, UTM coordinates WN586482, alt. 625 m; 11 Apr. 1984 (sta. 84-4/23), in slowly running water in twilight zone, 1 ovigerous $\$$ and 3 juvs.

Prov. Navarra, Larraún, Nacimiento del Río Araxes, N. of the road Pamplona-San Sebastián (N240), $3.5 \mathrm{~km}$ E. of Betelu, UTM coordinates WN865646, alt. $360 \mathrm{~m}$; 18 June 1984 (sta. 84-6/34), in fissures with running water, $1 \sigma^{\circ}$ and 1 damaged ovigerous $\%$.

Prov. Guipuzcoa, Oñate, caught spring (not karstic), $250 \mathrm{~m} \mathrm{~S}$. of Berezano, UTM coordinates WN4863, alt. $360 \mathrm{~m}$; 19 June 1984 (sta. 84-6/37), $1 \&$ and 3 damaged specimens.

Description. - Largest males and females, 5.6 and $6.0 \mathrm{~mm}$, respectively. Ovigerous females ranging from 5.2 to $5.9 \mathrm{~mm}$ (carrying 2-3 eggs).

Male: Antenna 1 about half as long as body; peduncle little longer than that of A2; accessory flagellum not exceeding length of flagellum segment 1; flagellum of 15-17 segments, aesthetascs about $3 / 4$ of length of corresponding segments. Antenna 2 as in gorbeanus.

Mandible palp slender, segment 2 with few ventral setae, segment 3 with 1-2 A-setae, $1 \mathrm{~B}$ seta, 8-10 D-setae and 3 E-setae. Maxilla 1: outer lobe with 1 multidenticulate inner spine. Other mouthparts without peculiarities.

Gnathopod 1 as in gorbeanus. Gnathopod 2 (fig. 19e): coxal plate with narrow lower margin and 5-7 setae (one very long); posterior margins of carpus and propodus with up to 4 and 5 groups of setae, respectively; palmar angle in general with 3 spines, but in a $5.6 \mathrm{~mm}$ long male 4 spines are present; unguis $1 / 2-1 / 3$ of length of dactylus.

Dactylus and unguis of P3-P7 very slender, as in gorbeanus. Coxal plates 3 and 4 (figs. 20a, l) narrow, armed with 4-9 and 6-11 setae, respectively. Setation on coxae 3 and 4 not restricted to the distal margin only, as in many specimens the posterodistal margin is bearing setae as well. Pereiopods 5 to 7 (figs. $19 \mathrm{~g}, \mathrm{f}$, i \& 20e, f, g): posterior lobes of basis wide (much wider than in gorbeanus) and overhanging in varying degree; with exception of the basis, P5 to $\mathrm{P} 7$ similar to those of gorbeanus. P5 (figs. $19 \mathrm{~g}$ \& 20e) with 6-11 elements on anterior basal margin, posterior margin with 9-16 setules; P6 (figs. 19f \& 20f) with 5-9 elements anteriorly and 


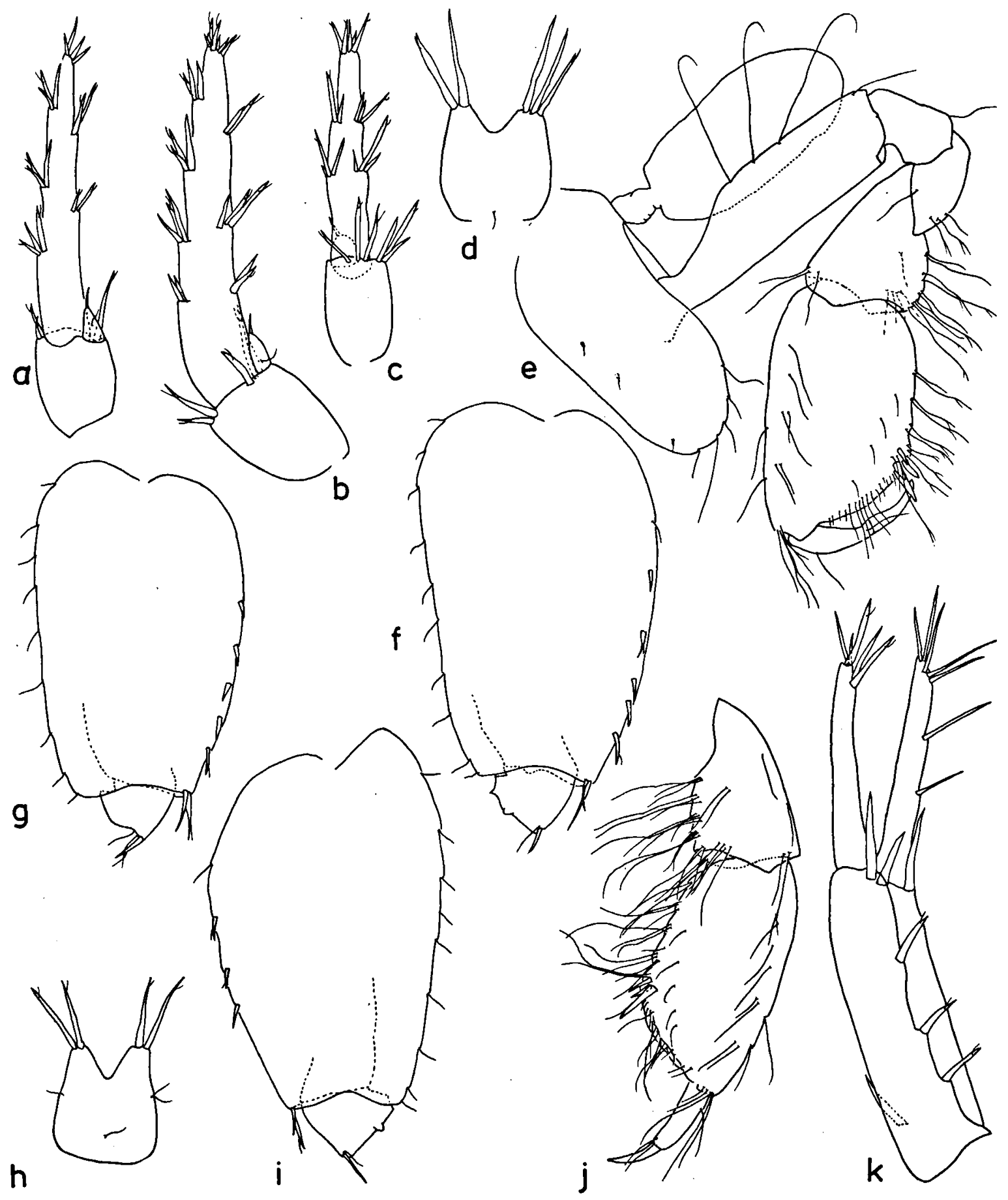

Fig. 19. Pseudoniphargus vasconiensis n. sp. (a, o paratype $5.5 \mathrm{~mm}$; b, d, Q ovigerous paratype $5.7 \mathrm{~mm}$; e, ơ paratype $5.6 \mathrm{~mm} ; \mathrm{f}, \mathrm{g}, \mathrm{i}$, o paratype $4.8 \mathrm{~mm}$, all from Cueva de Allí; c, h, j, k, $\$$ ovigerous $5.2 \mathrm{~mm}$ from Cueva de Porraipi): a, uropod 3 o (scale A); b, uropod 3 ㅇ (A); c, uropod 3 ㅇ (A); d, telson 9 (A); e, gnathopod $20^{\prime \prime}$ (A); f, basis pereiopod $60^{\circ}(\mathrm{A})$; $\mathrm{g}$, basis pereiopod $5 \sigma^{\circ}(\mathrm{A})$; $\mathrm{h}$, telson $\$$ (A); i, basis pereiopod $70^{\circ}(\mathrm{A}) ; \mathrm{j}$, distal part gnathopod 2 ( uropod 1 ㅇ (A). 

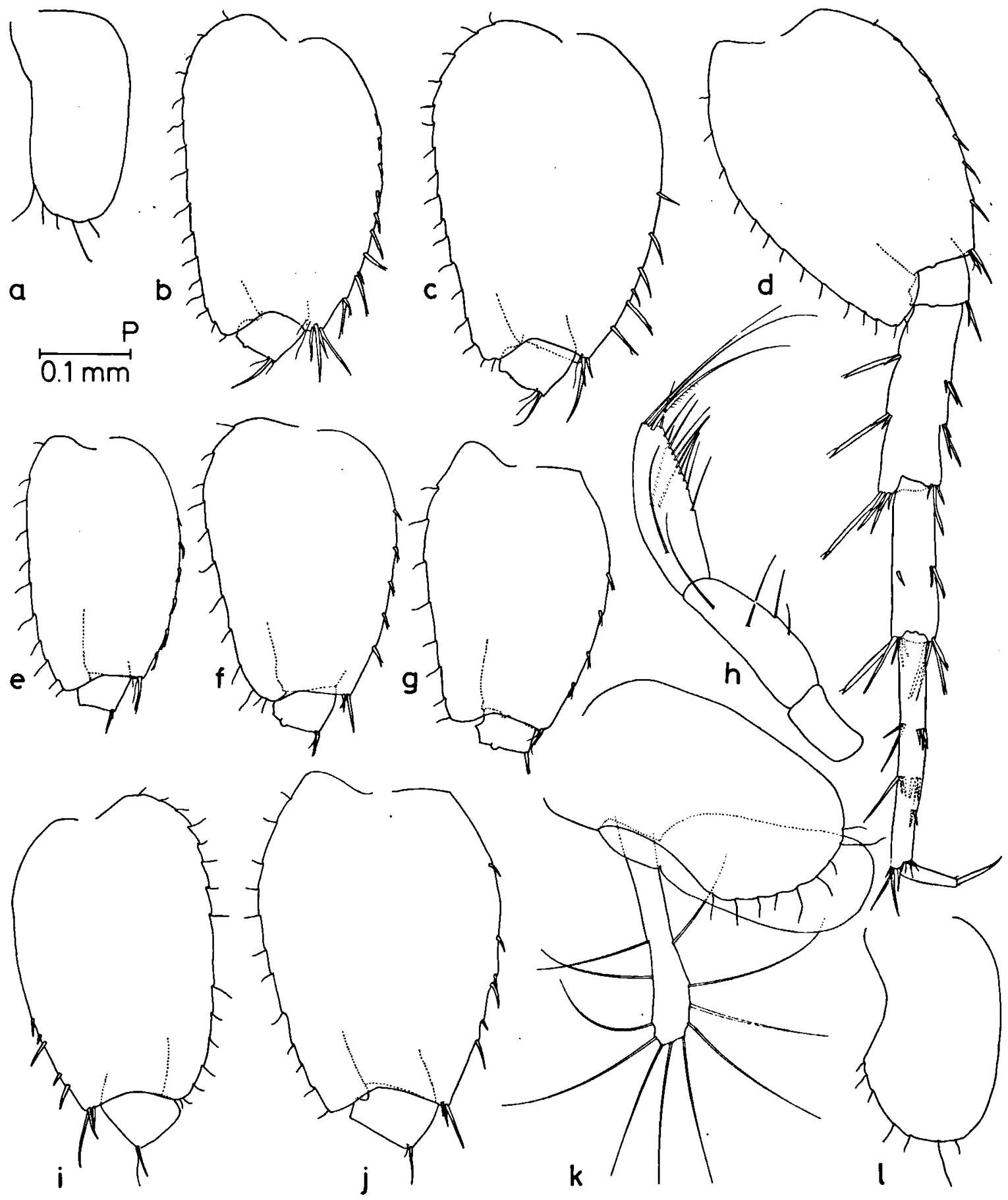
10-17 setules posteriorly; P7 (figs. 19i \& 20g) with 3-7 elements anteriorly and 7-14 setules posteriorly (several specimens with rather long spines on distal part of anterior margin).

Epimera similar to those of gorbeanus.

Uropods 1 and 2 as in gorbeanus. Uropod 3 (fig. 19a): peduncle not elongated (about 1.3 times as long as wide); exopodite 5.5-5.7 times longer than wide, margins armed with 2-4 spine groups, each group with up to 3(-4) spines, terminal spines shorter than lateral spines.

Telson hardly longer than wide, tapering, with deep V-shaped distal emargination and 23 terminal spines on either side.

Female: Gnathopod 2 (fig. 19j) more slender than in male. Oostegites (fig. 20k) with 10-12 setae. Remaining characters as in male. Figured are mandible palp (fig. 20h), gnathopod 2 (fig. 19j), coxa 4 (fig. 20k), basis of pereiopods 5 to 7 (figs. 20b, c, d, i, j), pereiopod 7 (fig. 20d), uropod 1 (fig. 19k), uropod 3 (figs. 19b, c), and telson (figs. 19d, h).

Remarks. - There is a large intraspecific variation in the basis of P5 to P7, both in chaetotaxy, and in shape of the posterodistal lobe. This variability has been found in specimens from various localities, but also in individuals of the population from Cueva de Alli. Specimens are found in which the posterodistal angle of the basis is strongly overhanging, but also specimens of the same size with moderately overhanging angles were encountered. Most strongly overhanging is the posterodistal angle of the basis of P7 (fig. 20d) of a $5.2 \mathrm{~mm}$ large ovigerous female from Cueva de Porraipi.

When the morphology of the basis shows no strongly overhanging posterodistal angle and a low number of short spines on the anterior margin, it resembles strongly that of gorbeanus; however, posterior lobes are weakly developed in the latter species. But a morphology as in vasconiensis, with strongly overhanging posterodistal angle and long spines on the anterior margin, was never found in gorbeanus.

Other differences, although small, between gorbeanus and vasconiensis are: number of D-setae on the mandible palp, and shape and setation of coxal plates 2-4.

Etymology. - The proposed specific name vasconiensis refers to Basque (= Vasco) Country in which this species has a large distribution.

\section{Pseudoniphargus unisexualis Stock, 1980}

(Fig. 21)

Stock, 1980: 127-130, figs. 16-17.

Material examined. - Holotype $\sigma$, allotype $\$$, and 16 paratypes, from the only known locality. Prov. Guipuzcoa, Cueva de San Adrian de Cegama, UTM coordinates WN559539, alt. $1060 \mathrm{~m}$; 1 Aug. 1979, in completely dark, second (= terminal) basin, left of the chapel; leg. J. H. Stock (ZMA coll. no. Amph. 107.341-343).

Descriptive notes, supplementing Stock's description. - Largest males and females 7.0 and $8.5 \mathrm{~mm}$, respectively.

Male: Mandible palp (fig. 21h): segment 1 rather long, segment 2 with several marginal setae, segment 3 with 1-2 A-setae, 2-3 B-setae, 14-15 D-setae, and 3 E-setae. Outer lobe of maxilla 1 (fig. 21e) with 5 multidenticulate spines. Other mouthparts without peculiarities.

Gnathopod 2 with short carpus, strong propodus with S-shaped palmar margin.

Coxal plate 3 (fig. 21b): convex lower margin with 3 or 4 setae. Coxa of pereiopod 4 (fig. 21c) small with shallow posterior excavation and 4 distal setae. Dactylus and unguis of P3 to P7 not slender. Basis of P5 to P7 (figs. 21f, g, d) rectangular, with straight margins, weakly developed posterior lobes, not overhanging.

Uropod 3: peduncle short (1-1.5 times as long as wide); exopodite about 6-10 times as long as wide, margins with 2-4 groups of spines, each group consisting of up to 3 spines, terminal spines shorter than lateral spines.

Female: Palmar margin of P2 (fig. 21a) less Sshaped than in male. Remaining characteristics as in male.

Remarks. - In spite of intensive sampling in south Guipuzcoa and north Alava, this species has not been found at other localities than the Cueva de San Adrian. Probably unisexualis is an 


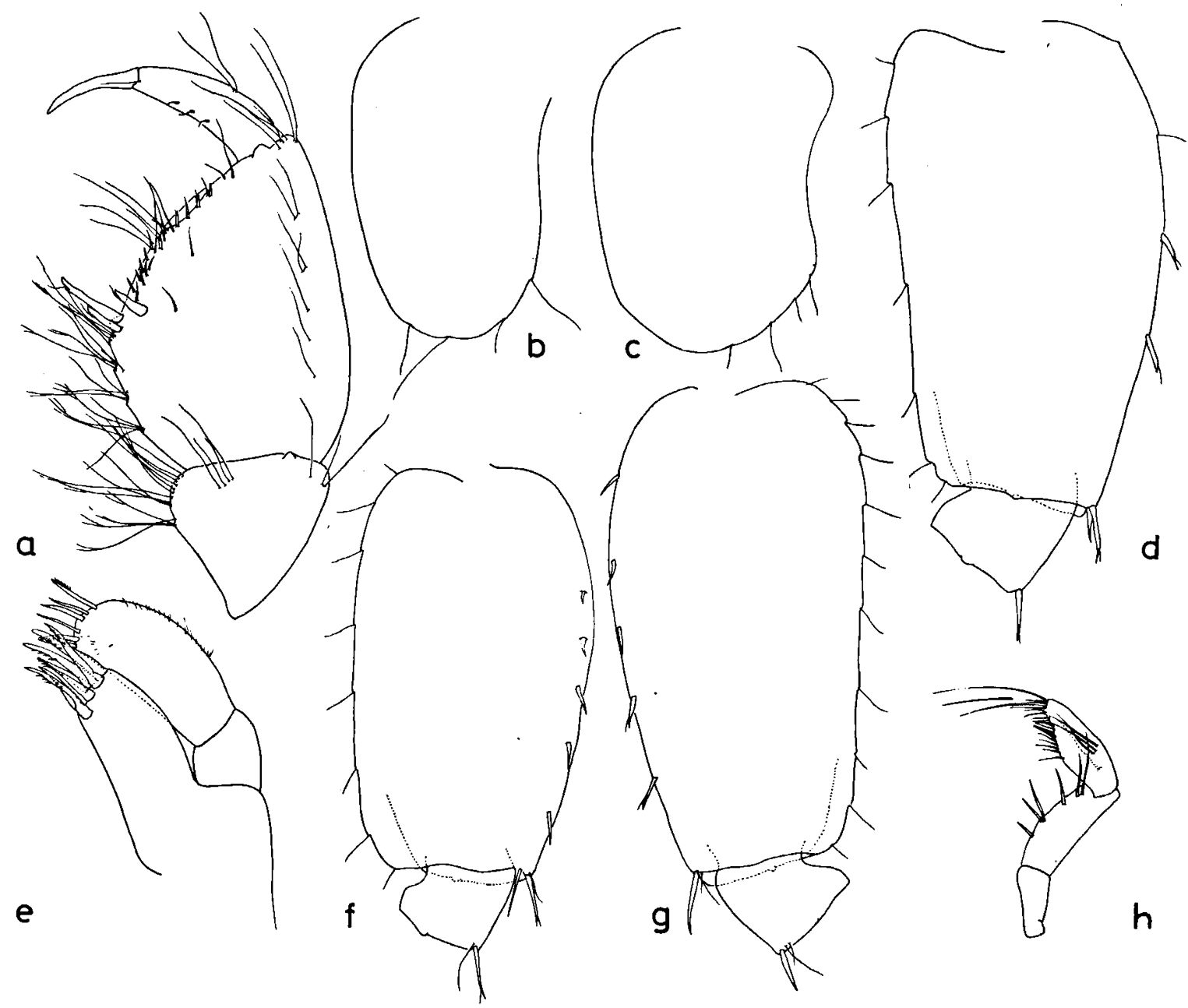

Fig. 21. Pseudoniphargus unisexualis Stock, 1980 (a, \& ovigerous allotype $6.5 \mathrm{~mm}$; b-d, f, g, ơ holotype $7.0 \mathrm{~mm}$; e, h, $\sigma$ paratype $6.5 \mathrm{~mm}$, all from Cueva de San Adrian): a, distal part gnathopod 2 ( (scale M); b, coxal plate pereiopod $3 \sigma^{\circ}(\mathrm{M})$; c, coxal plate pereiopod $4 \sigma^{\circ}(\mathrm{M})$; d, basis pereiopod $7 \sigma^{\circ}(\mathrm{M})$; e, maxilla 1 o $^{\circ}(\mathrm{P})$; f, basis pereiopod $5 \sigma^{\circ}$ $(\mathrm{M}) ; \mathrm{g}$, basis pereiopod $60^{\circ}(\mathrm{M}) ; \mathrm{h}$, mandible palp $\sigma^{\circ}(\mathrm{P})$.

endemic of the karst situated at high altitudes in the Sierra de Urkilla. At lower altitudes around this mountain ridge vasconiensis has been found in three springs, two of which are karstic.

\section{Pseudoniphargus incantatus $\mathrm{n}$. sp.}

(Figs. 22-24)

Pseudoniphargus sp. 4; Stock, 1980: 140.

Pseudoniphargus cf. elongatus, from Landarbaso; Stock, 1980: 137.

Material examined. - Prov. Navarra, Zugarramurdi, Cuevas de las Brujas, UTM coordinates XN179919, alt. $190 \mathrm{~m}$; 16 June 1984 (sta. 84-6/25), in pool with loamy substrate, 10 holotype, 1 allotype and about 75 paratypes (ZMA coll. no. Amph. 108.025). Same locality; 19 July 1979, 6 specimens; leg. J. H., M. D. Stock (ZMA coll. no. Amph. 107.335).

Prov. Guipuzcoa, Renteria, Aizpitarte, Cueva de Landarbaso, UTM coordinates WN898907, alt. $220 \mathrm{~m} ; 14$ Nov. 1983 (sta. 83-11/28), in little stream, 2 \% $\%$ and 1 juv.

Prov. Guipuzcoa, San Sebastián, caught spring near Cueva de Landarbaso, UTM coordinates WN896907, alt. $200 \mathrm{~m}$; 14 Nov. 1983 (sta. 83-11/29), in stream between boulders, $1 \%$ and 1 juv.

Prov. Navarra, Urdáx, Leorlás, Gruta de Urdáx, UTM coordinates XN207928, alt. $100 \mathrm{~m}$; 16 June 1984 (sta. 84-6/24), in rimstone pool, 3 damaged specimens. 

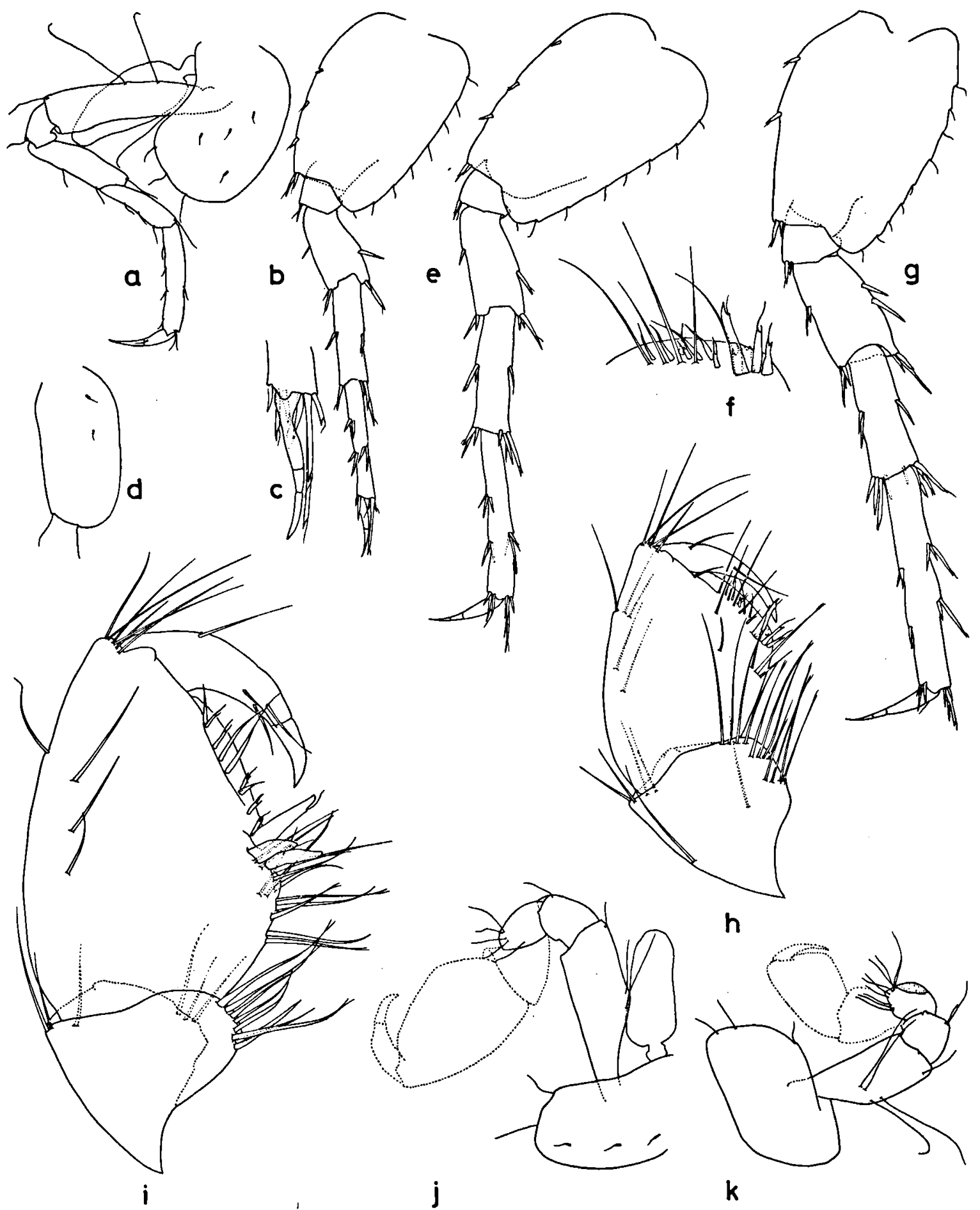

Fig. 22. Pseudoniphargus incantatus n. sp. (O paratype $3.6 \mathrm{~mm}$ ): a, pereiopod 4 (scale F); b, pereiopod 5 (F); c, claw pereiopod $5(\mathrm{H})$; d, coxal plate pereiopod $3(\mathrm{~F})$; e, pereiopod $6(\mathrm{~F})$; f, palmar angle gnathopod $1(\mathrm{G}) ; \mathrm{g}$, pereiopod 7 (F); h, distal part gnathopod $1(\mathrm{H})$; i, distal part gnathopod 2 (H); j, gnathopod 2 (F); k, gnathopod 1 (F). 
Prov. Navarra, Yanci, little karst spring near Ermita de San Juan, UTM coordinates XN050852, alt. 140 m; 17 June 1984 (sta. 84-6/30), in crevices with running water, 7 specimens.

Prov. Navarra, Yanci, mine gallery E. of the road (C133) from Sumbilla to Vera de Bidasoa, $2.6 \mathrm{~km} \mathrm{~S}$. of Ventas de Yanci, UTM coordinates XN081857, alt. 80 m; 17 June 1984 (sta. 84-6/31), in pools, 2 ণo , 8 \& , and 7 juvs.

Description. - Largest males and females 4.0 and $3.5 \mathrm{~mm}$, respectively.

Male: Antenna 1 (fig. 24f) 33-55\% of body length; peduncle shorter than that of A2; flagellum of 12 segments, aesthetascs about half as long as corresponding segments. Antenna 2 (fig. 24e): peduncle segment 4 with few setae and 2 distal spines, segment 5 with long setae reaching beyond flagellum segment 1 ; flagellum of 7 segments, proximal segments with setae being longer than segmental width.

Mandible palp (fig. $24 \mathrm{j}$ ): segment 2 poorly setose, segment 3 armed with 1 A-seta, 1 Bseta, $7 \mathrm{D}$-setae and $3 \mathrm{E}$-setae. Maxilla 1: outer lobe with 1 bidenticulate inner spine, other spines unidenticulate. Lower lip (fig. 24k) with rather large inner lobes. Other mouthparts without peculiarities.

Gnathopod 1 (figs. 22k, h): anterior margin of coxa straight, distal margin with 3 long setae; carpus rather wide, little shorter than propodus, posterior margin with 3 setal rows, propodal posterior margin with 1 setal group; palmar angle (fig. 22f) with 5 spines. Gnathopod 2 (figs. 22i, j): coxa with straight posterior margin and 2 long setae on distal margin; carpus short, armed with 1 or 2 setal groups on posterior margin; propodus robust with oblique palma, posterior margin with 3 setal groups, palmar angle with 3 spines.

Pereiopods 3 and 4 (fig. 22a) with short dactylus and long unguis; coxa 3 (fig. 22d) with straight posterior margin and 2 long distal setae, coxa 4 with shallow posterior excavation and 3 distal setae.

Basis of P5 to P7 (figs. 22b, e, g) with wide and overhanging posterior lobes; distal spines on propodus long, especially in P5 (fig. 22c); dactylus and unguis elongated. Basis of P5 (fig. 22b) with 3-4 little spines anteriorly, and 7-9 setules posteriorly. P6 (fig. 22e) with slightly longer basis than in $\mathrm{P} 5$, anterior margin with 3 spines, posterior margin with 8 setules. P7 (fig. $22 \mathrm{~g}$ ): basis of same size as in P6, with 2 anterior spines and 9 posterior setules, posterodistal angle more strongly overhanging than in P5 and P6.

Epimera rectangular, plates 1 and 2 with pointed posteroventral corner, lower margin unarmed, posterior margin scarcely armed with setules.

Uropod 1 (fig. 24g): peduncle slender, basoventral spine slender, medial spines absent, 0-1 dorsal spine; rami slender without marginal armature. Uropod 2 (fig. 24h): peduncle without dorsal spines; rami slender, margins unarmed. Uropod 3 (fig. 24b): peduncle about 1.5 times as long as wide; exopodite 5.5-7.5 times longer than wide, margins with 13 groups of spines, each group consisting of up to 2 spines, terminal spines of equal length or somewhat longer than lateral spines.

Telson (fig. 24c) wider than long with wide $\mathrm{V}$-shaped apical notch, each side with 2-5 terminal spines.

Female: Gnathopod 2 (fig. 23a) different from that of male, carpus more elongated, propodus slender with less oblique palma and 3 setal rows on posterior margin, unguis more slender. Oostegites (fig. 24i) with 2-3 distal setae. Posterodistal angle of basis P5-P7 (figs. 23c, d, e) somewhat more strongly overhanging. Other characters, like gnathopod 1 (fig. 23b), uropod 3 (fig. 24d), and telson (fig. 24a), similar to those of male.

Remarks. - This is a small species, well characterized by its short antennae, mandible palp, gnathopod 2, very slender claws, and wide distal notch on telson. It is closely related to guernicae, see remarks under the latter species. The small size of this species brought Stock to regard it as juvenile elongatus.

Etymology. - The specific name incantatus (from the Latin, meaning "under influence of a magic song") is proposed for this species because the type-locality Cueva de las Brujas (= Cave of the Witches) is a mythological site where séances of witches took place. 


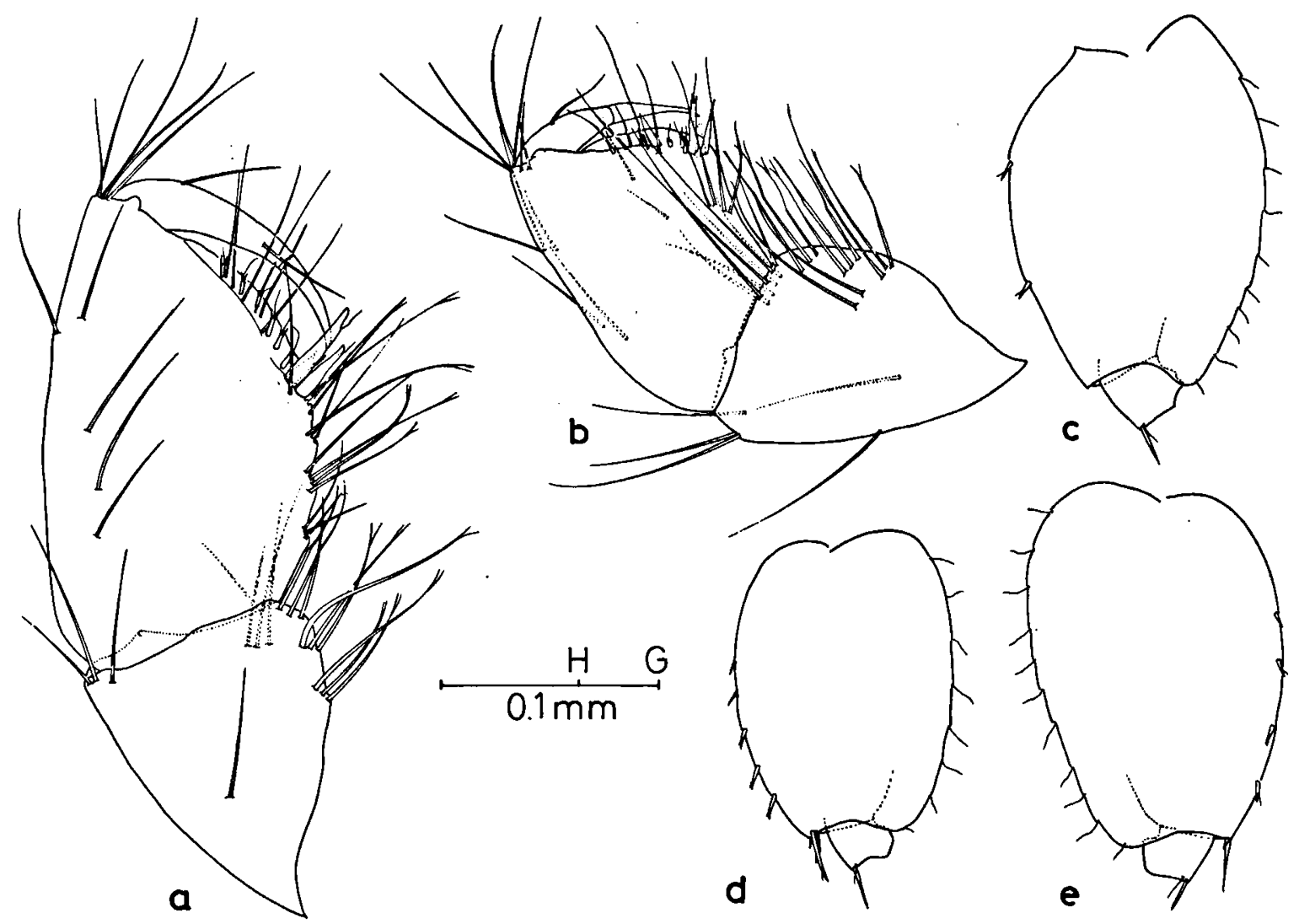

Fig. 23. Pseudoniphargus incantatus n. sp. (\$ paratype $3.5 \mathrm{~mm}$ ): a, distal part gnathopod 2 (scale H); b, distal part gnathopod $1(\mathrm{H})$; c, basis pereiopod $7(\mathrm{~F})$; d, basis pereiopod $5(\mathrm{~F})$; e, basis pereiopod $6(\mathrm{~F})$.

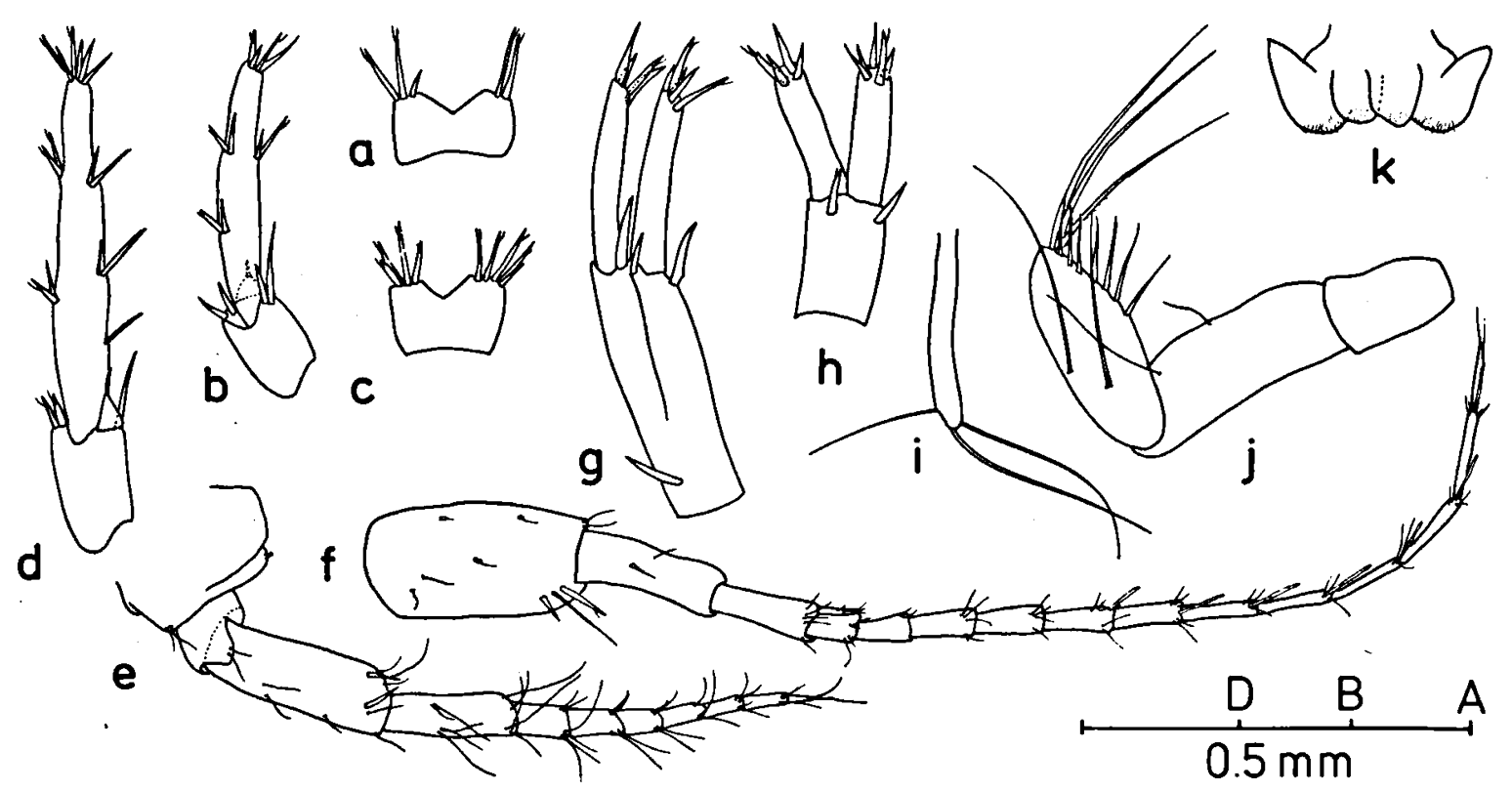

Fig. 24. Pseudoniphargus incantatus n. sp. (a, d, \& paratype $3.5 \mathrm{~mm}$; b, c, e-h, j, k, o paratype $3.6 \mathrm{~mm}$; i, $\$$ paratype

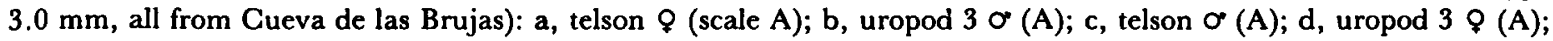
e, antenna $2 \sigma^{\circ}(A) ; f$, antenna $1 \sigma^{\circ}(A) ; g$, uropod $1 \sigma^{\circ}(A) ; h$, uropod $2 \circ(A) ;$ i, oostegite pereiopod 3 o (A); j, mandible palp $\sigma^{\circ}(\mathrm{C})$; k, lower lip $\sigma^{\circ}(\mathrm{C})$. 
Pseudoniphargus guernicae n. sp.

(Figs. 25-27)

Material examined. - Prov. Vizcaya, Busturia, Altamira de San Cristobal, Manantial de Iturgoyen (resurgence cave), UTM coordinates WP242013, alt. 20 $\mathrm{m} ; 20$ June 1984 (sta. 84-6/42), in muddy gallery with slowly running water, $1 \sigma^{\circ}$ holotype, 1 \% allotype, $3 \sigma^{\circ} \sigma^{\circ}$, $1 \%$, and 1 juv. (paratypes) (ZMA coll. no. Amph. 107.971).

Prov. Vizcaya, Busturia, Axpe de Busturia, Cueva de San Pedro (resurgence cave), UTM coordinates WP243034, alt. $40 \mathrm{~m}$; 30 Nov. 1983 (sta. 83-11/49), in slowly running subterranean river, substrate: loam, silt and gravel, 2 ○ం 3 \&, 6 juvs., and 4 damaged specimens.

Prov. Vizcaya, Gautéguiz de Arteaga, Celayetas, Manantial Rekalde 3 (caught karst spring), UTM coordinates WP287005, alt. $40 \mathrm{~m}$; 1 Dec. 1983 (sta. 83-12/3), in upwelling water between gravel and boulders, 2 o' and $1 \%$.

Prov. Vizcaya, Gautéguiz de Arteaga, Argatxa, Cueva de Argatxa, UTM coordinates WP277009, alt. $10 \mathrm{~m} ; 20$ June 1984 (sta. 84-6/41), in subterranean lake between boulders, 1 \& and 3 juvs. (probably this species).

Description. - Largest male and female (with setose oostegites) 3.8 and $4.0 \mathrm{~mm}$, respectively. No ovigerous females present.

Male: Antenna 1 about half as long as body; peduncle somewhat longer than peduncle of A2; flagellum about 16-segmented, aesthetascs half as long as corresponding segments. Antenna 2 slender; peduncle segment 4 with few setae and 2 distal spines, segment 5 with several long distal setae; flagellum of about 6 segments, proximal segments with long setae.

Maxilla 1: outer lobe with 2 multidenticulate spines. Inner lobes of lower lip (fig. 27e) narrower than in incantatus. Other mouthparts, like mandible palp (fig. 27g), similar to incantatus.

Gnathopod 1 (fig. 25f) as in incantatus. Gnathopod 2 (fig. 25c): coxal plate with 2 long distal setae; carpus more elongated than in incantatus with 3 setal rows on posterior margin; propodus wide, posterior margin with 3 groups of setae, palmar angle with 3 spines.

Pereiopod 3 as in incantatus, but setae on lower margin of coxa (fig. 25b) shorter and claw more slender. Pereiopod 4 (fig. 25g): coxal plate wider than in incantatus, armed with 3-4 distal setae (which are shorter than in incantatus), claw slender.
Pereiopods 5 to 7 (figs. 25h, d, e): basis with wide, slightly overhanging posterior lobe, proximal part of anterior margin scarcely armed. Smaller specimens have wider basis with more strongly overhanging posterodistal lobe. Dactylus and unguis very slender. P5 (fig. 25h) with 5 small elements on anterior margin of basis, and 6-9 setules posteriorly. Basis of P6 (fig. 25d) with 4-5 small spines anteriorly, and 8-9 setules posteriorly. P7 (fig. 25e): anterior margin of basis with 4-5 small elements, posterior margin with 7-8 setules.

Epimeral plates (fig. 25i) with rounded, unarmed lower margin; posteroventral corner of plates 2 and 3 acute and armed with a setule; posterior margin unarmed.

Uropods 1 and 2 (figs. 27c, d) as in incantatus, but with slender terminal spines on rami. Uropod 3 (fig. 27b): peduncle about twice longer than wide; exopodite 7.0-9.5 times as long as wide, margins armed with 1-3 groups of spines, each group consisting of 2(-3) slender spines, terminal spines very slender, longer than lateral spines.

Telson (fig. 27f) hardly wider than long, with wide $\mathrm{V}$-shaped distal notch, each side armed with 2 terminal spines.

Female: Propodus of gnathopod 2 (fig. 25a) slightly narrower. Oostegites (fig. 27h) with 4-6 distal setae. Other characters as in male. Basis of pereiopods 5 to 7 (fig. 26), and uropod 3 (fig. 27 a) illustrated.

Remarks. - The female from Argatxa (3.5 $\mathrm{mm}$ with setose oostegites) has P7 with extended basis and strongly overhanging posterodistal angle (P5 and P6 are lacking); carpus and propodus of $\mathrm{P} 2$ are of equal length and very slender. Since the other features of this animal conform those of guernicae, and the locality is situated within the range of guernicae, I have some doubts about the taxonomic status of this specimen.

Ps. guernicae shows close affinities with incantatus; they differ principally in the morphology and degree of sexual differentiation of gnathopod 2. Other differences are the wider 


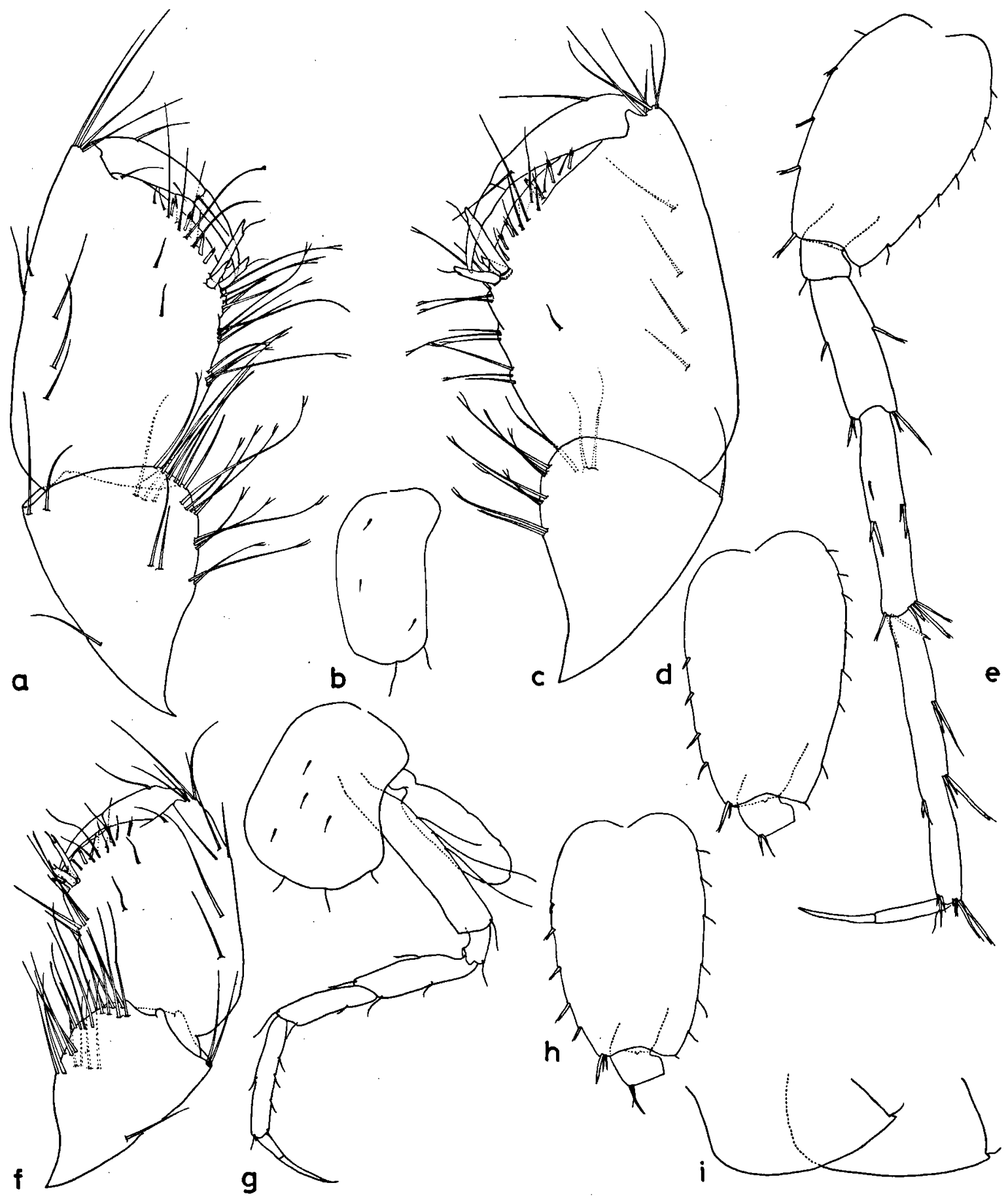

Fig. 25. Pseudoniphargus guernicae $\mathrm{n}$. sp. ( $\sigma^{\circ}$ holotype $3.5 \mathrm{~mm}$; $\odot$ allotype $4.0 \mathrm{~mm}$, from Manantial de Iturgoyen): a, distal part gnathopod $2 \%$ (scale $\mathrm{H}$ ); b, coxal plate pereiopod $3 \sigma^{\circ}(\mathrm{F})$; c, distal part gnathopod $2 \sigma^{\circ}(\mathrm{H})$; d, basis pereiopod $6 \sigma^{\circ}(\mathrm{F})$; e, pereiopod $7 \sigma^{\circ}(\mathrm{F})$; f, distal part gnathopod $10^{\circ}(\mathrm{H})$; g, pereiopod $4 \mathrm{O}^{\circ}(\mathrm{F})$; h, basis pereiopod $5 \mathrm{O}^{\circ}(\mathrm{F})$; i, epimera 2 and $3 \sigma^{\circ}(\mathrm{F})$. 


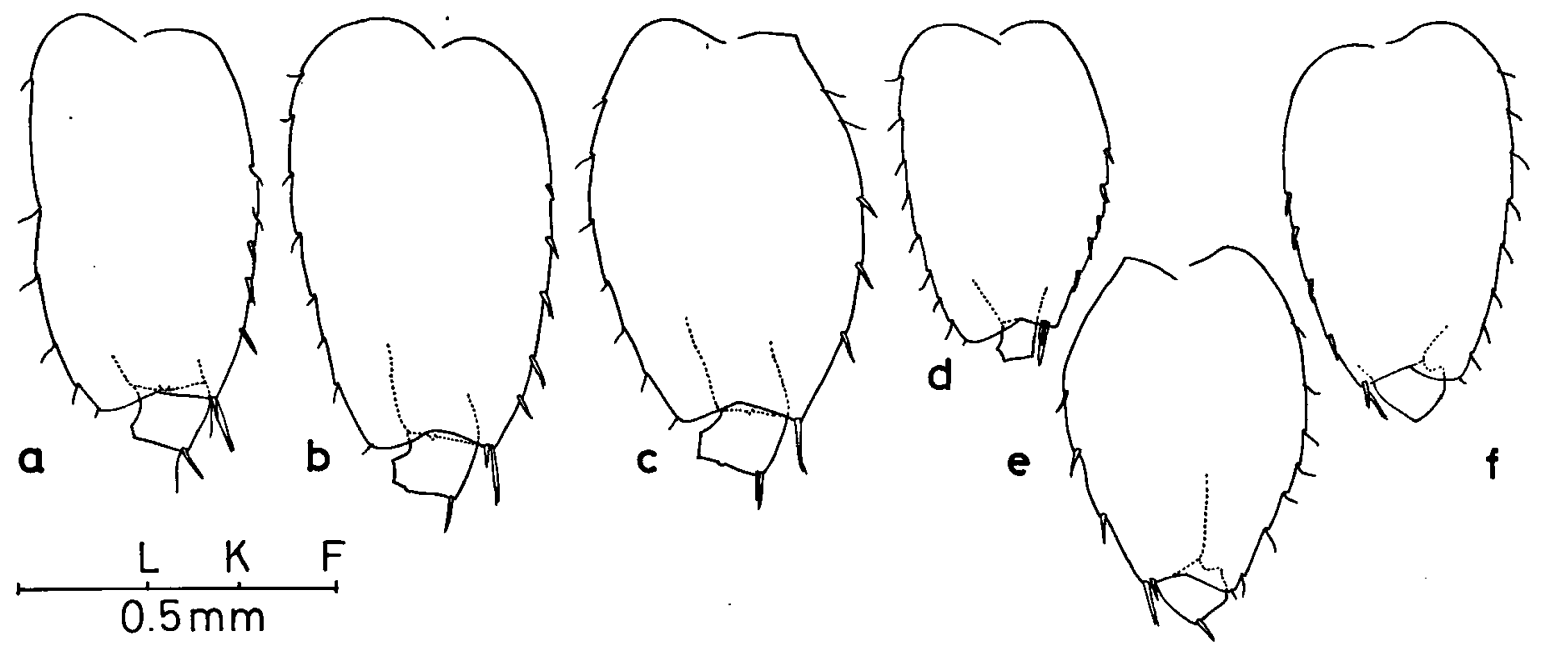

Fig. 26. Pseudoniphargus guernicae $n . \mathrm{sp}$. (a-c, $\$$ allotype $4.0 \mathrm{~mm}$ from Manantial de Iturgoyen; d-f, $\$ 2.7 \mathrm{~mm}$ from Cueva de San Pedro): a, basis pereiopod 5 ९ (scale F); b, basis pereiopod 6 ९ (F); c, basis pereiopod 7 \& (F); d, basis pereiopod 5 ९ (F); e, basis pereiopod 7 \% (F); f, basis pereiopod 6 \% (F).
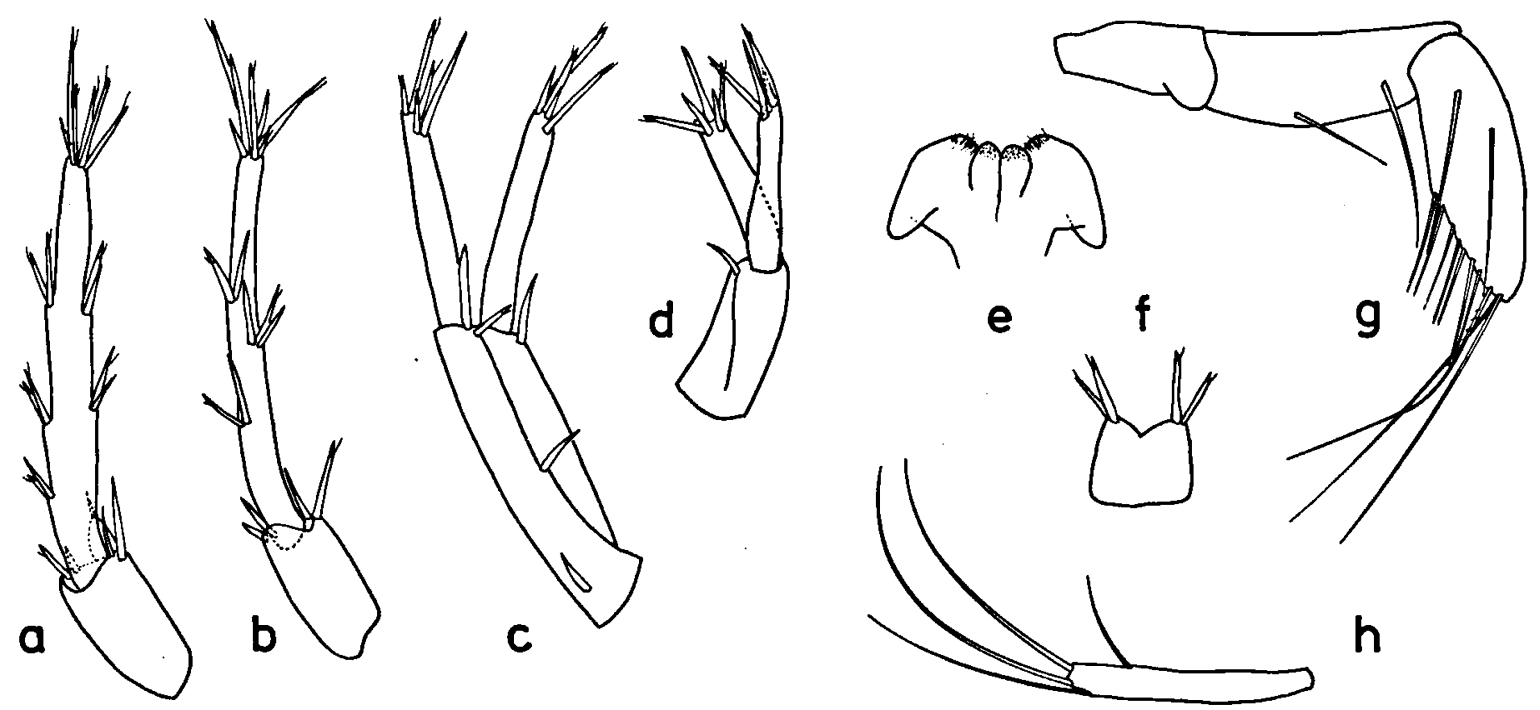

Fig. 27. Pseudoniphargus guernicae n. sp. ( $\sigma$ holotype $3.5 \mathrm{~mm}$; $Q$ allotype $4.0 \mathrm{~mm}$, from Manantial de Iturgoyen): a, uropod 3 \% (scale A); b, uropod $30^{\circ}$ (A); c, uropod $10^{\circ}$ (A); d, uropod $2 \sigma^{\circ}$ (A); e, lower lip $0^{\circ}$ (A); f, telson $\sigma^{\circ}$ (A); $\mathrm{g}$, mandible palp $\sigma^{\circ}(\mathrm{C}) ; \mathrm{h}$, oostegite pereiopod 3 \& (A).

inner lobes of the lower lip of incantatus, and the claws of P3-P7 which are more slender in guernicae.

Etymology. - The proposed specific name guernicae is a toponym referring to the town of
Guernica in the surroundings of which the species was found. This town is a centre of Basque cultural life and well known because of the bombing by the Nazis during the Spanish civil war and the painting of Picasso based on that event. 
Pseudoniphargus spiniferus $\mathrm{n}$. sp. (Figs. 28-29)

Material examined. - Prov. Navarra, Urraul Bajo, Ripodas, SBR Río Areta near the bridge to Lumbier, UTM coordinates XN391274, alt. $420 \mathrm{~m} ; 14$ June 1984 (sta. 84-6/19), $10^{\circ}$ holotype, 1 \% allotype, $60^{\circ} \sigma^{\circ}$ and 10 ९ \& (paratypes) (ZMA coll. no. Amph. 108.024).

Description. - Largest male and female 6.5 and $9.0 \mathrm{~mm}$, respectively. No ovigerous females present, but $9.0 \mathrm{~mm}$ long female bears setose oostegites.

Male: Antenna 1 (fig. 28e) about half as long as body; peduncle of equal length as peduncle of A2, segments only armed with short setae; accessory flagellum not exceeding the length of flagellum segment 1 ; flagellum of $16-18$ segments, aesthetascs about $2 / 3$ of length of corresponding segments. Antenna 2 (fig. $28 \mathrm{~m}$ ) with slender peduncle and short flagellum, armed with short setae only; flagellum of 6-7 segments.

Mandible palp (fig. $28 \mathrm{~g}$ ): segment 2 with several ventral setae, segment 3 with 3 A-setae, 2-3 B-setae, $12 \mathrm{D}$-setae and $3 \mathrm{E}$-setae. Lower lip (fig. 28f) with rather wide inner lobes. Maxilla 1: outer lobe with (2-)4 multidenticulate spines. Other mouthparts without peculiarities.

Gnathopod 1 (figs. 28i, b): coxa small, lower margin convex with 3-4 setae; carpus not elongated, rather globular, with 3-4 setal rows on posterior margin; propodal posterior margin with 3 setal groups, palmar angle (fig. 28c) with 4 bifid spines in smaller and 7 of these spines in larger specimens. Gnathopod 2 (figs. $28 \mathrm{~h}, \mathrm{a}$ ): coxal plate small, lower margin convex with 2-3 setae, stalk of gill long (fig. 28k); carpus short, posterior margin with 3-4 setal rows; propodus strong (resembles strongly unisexualis but is less globular), posterior margin with 4 groups of setae, palmar angle with 3 spines (one very long), palmar margin slightly S-shaped, armed with numerous bifid spinules and few setae.

Pereiopods 3 and 4 (fig. 28d) with small coxal plates, and short dactylus and unguis; plate 3 with convex distal margin bearing 3 setae, plate 4 with 3-4 distal setae.

Pereiopods 5 to 7 (figs. 29a-d): basis rectangular increasing in length from P5 to P7, anteriorly with 5-6 elements, posteriorly with 712 setules, posterior lobe weakly developed, not overhanging; merus, carpus and propodus of about equal width (fig. 29d); dactylus slender with short unguis (fig. 29h).

Epimera: distal margins of plates 1 and 2 unarmed, plate 3 with anterodistal spine. Posteroventral corners rectangular with small tooth, posterior margins armed with a few setules.

Uropod 1 (fig. $29 \mathrm{~m}$ ): peduncle slender, with strong basoventral spine, dorsal row of 2-4 spines, up to 2 medial spines, and distomedial spine 1/2 length of endopodite; rami short and robust, of equal length, endopodite marginally armed, terminal spines long. Uropod 2 (fig. 29i): peduncle dorsally armed with 3-4 spines, distally $2+2$ spines; rami short and robust, marginally armed with several spines, terminal spines strong. Uropod 3 (fig. 29k): peduncle about 1.3 times as long as wide; exopodite rather wide, 6-7 times longer than wide, margins armed with 2-3 spine groups, each group with up to 4 spines, terminal spines shorter than lateral spines.

Telson (fig. 29j) hardly longer than wide, with broad V-shaped distal emargination and 2-3 terminal spines on either side.

Female: Oostegites (figs. 28j, l) with about 7 setae; remaining characters, like basis of pereiopods 5 to 7 (figs. 29e, f, g), and uropod 3 (fig. 29-1), similar to those of male.

Remarks. - This species is rather similar to unisexualis, especially in gnathopods, coxal plates, basis of P5-P7, and uropod 3. Differences between the two species are found in particular in the armature of uropods 1 and 2, and in the shape of the telson. The two species unisexualis and spiniferus are the only species in the north of Spain in which the basis of P5 to P7 has straight margins, a weakly developed posterior lobe and no overhanging posterodistal angle.

Etymology. - The proposed specific name spiniferus (from the Latin, meaning "bearing spines"), alludes to the uropods which bear rather many spines. 


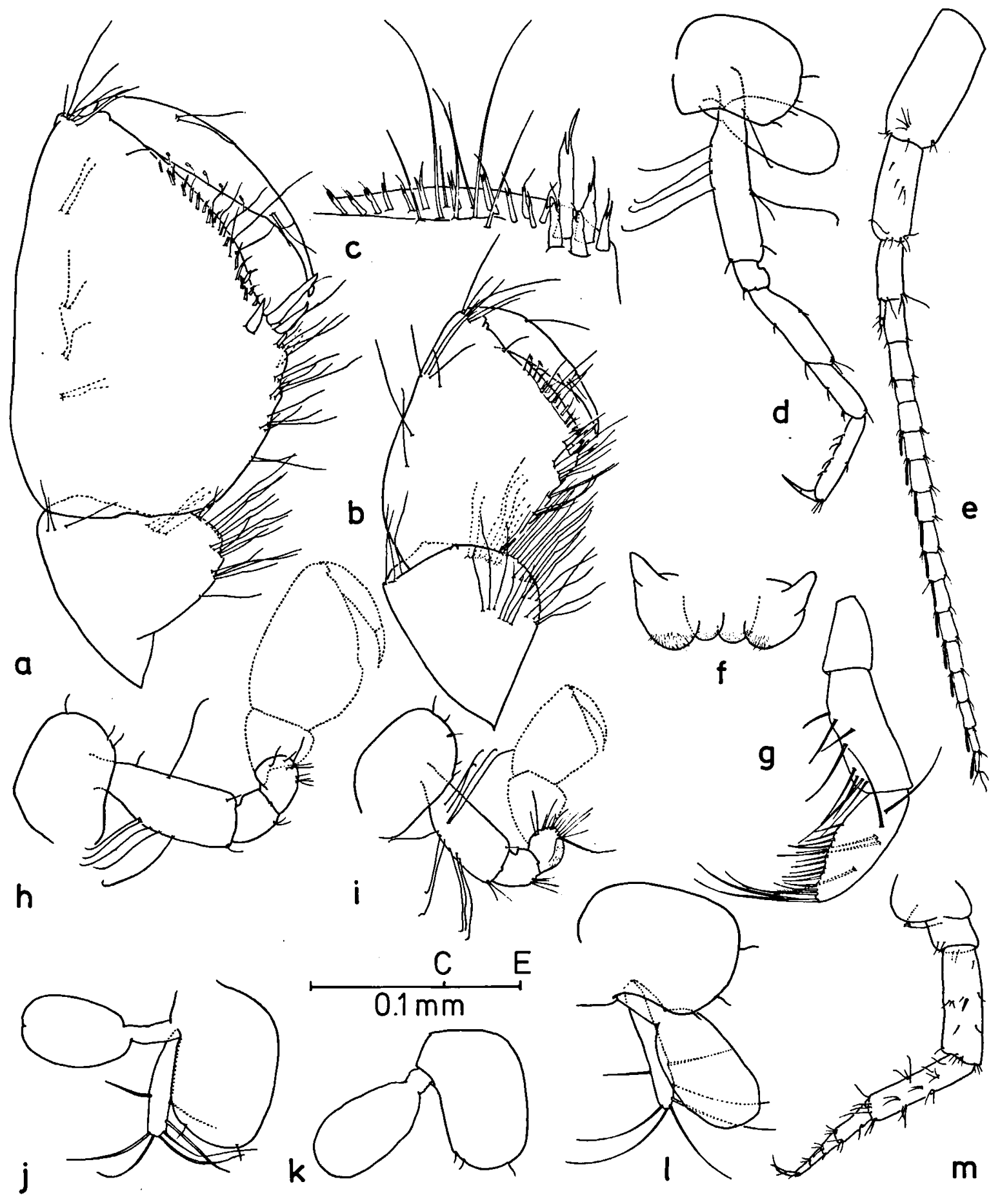

Fig. 28. Pseudoniphargus spiniferus $\mathrm{n}$. sp. (a-e, g-i, k, m, $\sigma$ holotype $6.5 \mathrm{~mm} ; \mathrm{j}, \mathrm{l}$, $\odot$ allotype $9.0 \mathrm{~mm}$; $\mathrm{f}$, o paratype 4.5 $\mathrm{mm}$, all from Río Areta): a, gnathopod $2 \sigma^{\circ}$ (scale A); b, gnathopod $10^{\circ}$ (A); c, palmar margin gnathopod $10^{\circ}(\mathrm{H})$; d, pereiopod $4 \sigma^{\circ}(\mathrm{D})$; e, antenna $10^{\circ}(\mathrm{D})$; f, lower lip $\sigma^{\circ}(\mathrm{A})$; g, mandible palp $\sigma^{\circ}(\mathrm{H})$; $h$, gnathopod 2 o $^{\circ}$ (D); i, gnathopod $1 \sigma^{\circ}(\mathrm{D}) ; \mathrm{j}$, coxal plate gnathopod 2, with gill and oostegite $९$ (D); $k$, coxal plate gnathopod 2, with gill $\sigma^{\circ}$ (D); l, coxal plate pereiopod 4, with gill and oostegite $Q$ (D); $m$, antenna $2 \sigma^{\circ}$ (D). 


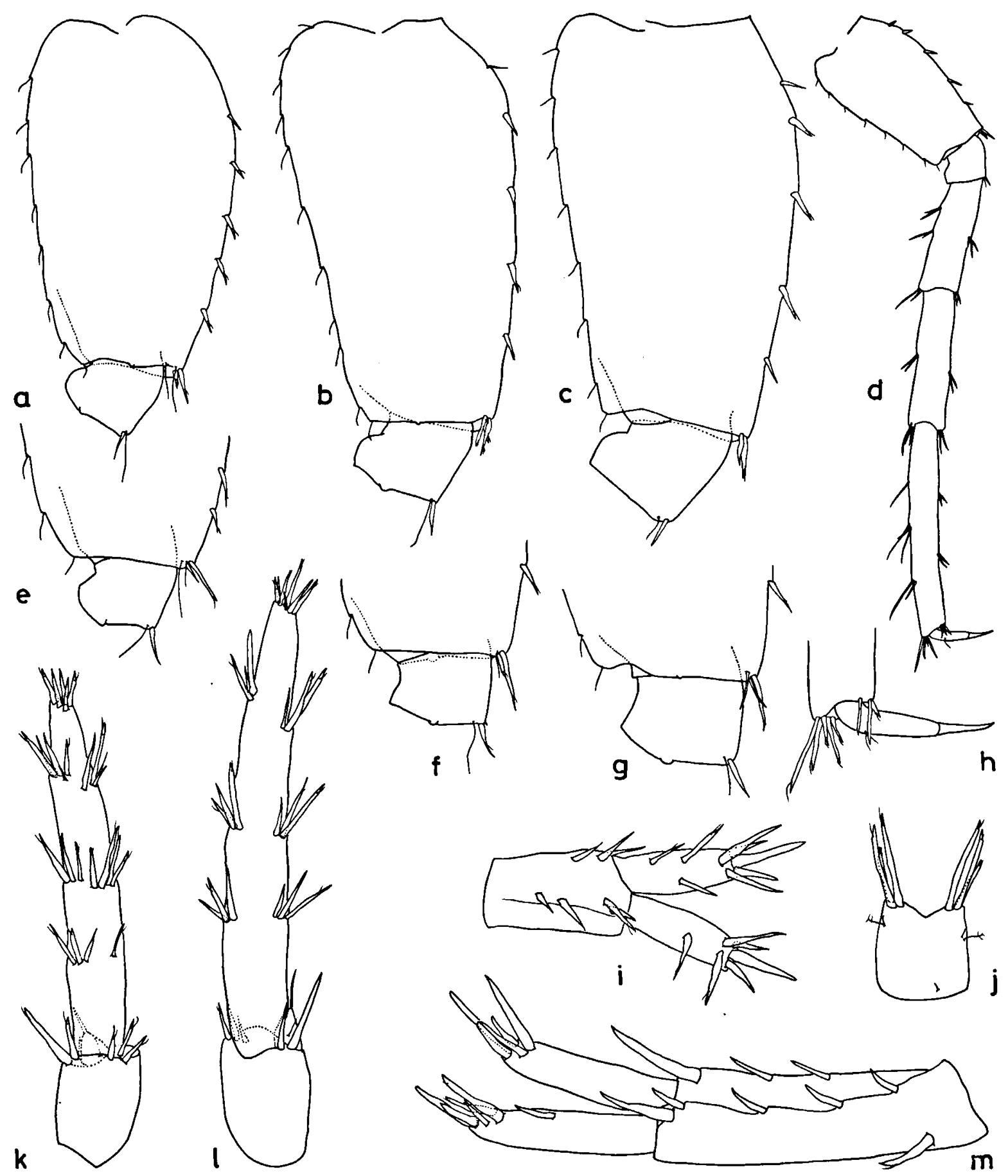

Fig. 29. Pseudoniphargus spiniferus n. sp. ( $\sigma$ holotype $6.5 \mathrm{~mm}$; $Q$ allotype $9.0 \mathrm{~mm}$, from Río Areta): a, basis pereiopod $5 \sigma^{\circ}$ (scale F); b, basis pereiopod $6 \sigma^{\circ}(\mathrm{F})$; c, basis pereiopod $7 \sigma^{\circ}(\mathrm{F})$; d, pereiopod $7 \sigma^{\circ}(\mathrm{L})$; e, distal part basis pereiopod 5 \& (F); f, distal part basis pereiopod 6 (F); g, distal part basis pereiopod $7 \%(\mathrm{~F})$; h, claw pereiopod 7 o $(\mathrm{F})$; i, uropod $2 \sigma^{\circ}(\mathrm{F}) ; \mathrm{j}$, telson $\sigma^{\circ}(\mathrm{F}) ; \mathrm{k}$, uropod $3 \mathrm{O}^{\circ}(\mathrm{F}) ; \mathrm{l}$, uropod 3 \% (F); m, uropod $1 \sigma^{\circ}(\mathrm{F})$. 


\section{ACKNOWLEDGEMENTS}

I would like to thank Prof. Dr. J. H. Stock for his practical suggestions and for reviews of the manuscript. Dr. L. Botosaneanu and Dr. S. Pinkster are thanked for their useful remarks about parts of the manuscript.

The investigations were supported by the Foundation for Fundamental Biological Research (BION), which is subsidized by the Netherlands Organisation for the Advancement of Pure Research (ZWO).

\section{REFERENCES}

Boutin, Cl. N. Coineau, in press. Pseudoniphargus maroccanus n. sp. (subterranean Amphipoda), the first representative of the genus in Morocco. Phylogenetic relationships and paleogeography. Crustaceana, Suppl. 12.

Chevreux, E., 1901. Amphipodes des eaux souterraines de France et d'Algérie, V. Pseudoniphargus africanus nov. gen. et sp. Bull. Soc. zool. Fr., 26: 211-216.

Collignan, B., 1985. Quelques éléments de géologie et d'hydrogéologie. In: P. Benort ed., Les Picos de Europa. Spelunca, Suppl. 19: 7-12.
Ginet, R., 1977. Amphipodes troglobies d'Espagne. Crustaceana, Suppl. 4: 173-176.

Gomarin Guirado, F., 1968. Bioespeleologia de "La Cuevona". Cuadernos de Espeleología, 3: 22.

Karaman, G. S., 1978. Revision of the genus Pseudoniphargus Chevreux 1901 (fam.Gammaridae). Boll. Mus. civ. Stor. nat. Verona, 5: 239-258.

Karaman, S. L., 1955. Über einige Amphipoden des Grundwassers der Jugoslavischen Meeresküste. Acta Mus. maced. Sci. nat., 2 (11/12): 223-241.

Margalef, R., 1970a. Anfípodos recolectados en aguas subterráneas del País Vasco. Munibe, 22 (3/4): 169-174.

- 1 , 1970b. Anfípodos recolectados en aguas subterráneas ibéricas. Speleon, 17: 63-65.

Notenboom, J. \& I. Meijers, 1985. Investigaciones sobre la fauna de las aguas subterráneas de España: Lista de estaciones e primeros resultados. Verslagen en technische Gegevens, Inst. taxon. Zoöl. Amsterdam, 42: $1-85$.

Schellenberg, A., 1937. Höhlenamphipoden Spaniens und ihre Beziehung zu Nordafrika. Zool. Anz., 118 (7/8): 223-224.

Srock, J. H., 1980. Regression model evolution as exemplified by the genus Pseudoniphargus (Amphipoda). Bijdr. Dierk., 50 (1): 105-144.

Received: 11 March 1986 